\title{
Het rendement van de opleidingskeuze van schoolverlaters van het VBO en de MAVO
}

Citation for published version (APA):

van Eijs, P. W. L. J., \& Farag, S. (2002). Het rendement van de opleidingskeuze van schoolverlaters van het VBO en de MAVO. Researchcentrum voor Onderwijs en Arbeidsmarkt, Faculteit der Economische Wetenschappen. ROA Reports No. 4 https://doi.org/10.26481/umarep.2002004

Document status and date:

Published: 01/01/2002

DOI:

10.26481/umarep.2002004

Document Version:

Publisher's PDF, also known as Version of record

\section{Please check the document version of this publication:}

- A submitted manuscript is the version of the article upon submission and before peer-review. There can be important differences between the submitted version and the official published version of record.

People interested in the research are advised to contact the author for the final version of the publication, or visit the DOI to the publisher's website.

- The final author version and the galley proof are versions of the publication after peer review.

- The final published version features the final layout of the paper including the volume, issue and page numbers.

Link to publication

\footnotetext{
General rights rights.

- You may freely distribute the URL identifying the publication in the public portal. please follow below link for the End User Agreement:

www.umlib.nl/taverne-license

Take down policy

If you believe that this document breaches copyright please contact us at:

repository@maastrichtuniversity.nl

providing details and we will investigate your claim.
}

Copyright and moral rights for the publications made accessible in the public portal are retained by the authors and/or other copyright owners and it is a condition of accessing publications that users recognise and abide by the legal requirements associated with these

- Users may download and print one copy of any publication from the public portal for the purpose of private study or research.

- You may not further distribute the material or use it for any profit-making activity or commercial gain

If the publication is distributed under the terms of Article $25 \mathrm{fa}$ of the Dutch Copyright Act, indicated by the "Taverne" license above, 


\section{Het rendement van de opleidingskeuze van schoolverlaters van het VBO en de MAVO}

ROA-R-2002/4

Patrick van Eijs

Sendy Farag

Researchcentrum voor Onderwijs en Arbeidsmarkt

Faculteit der Economische Wetenschappen en Bedrijfskunde Universiteit Maastricht

Maastricht, maart 2002 
ISBN 90-5321-330-9

Sec01.263.doc 


\section{Inhoud}

Bladzijde

Resumé

1 Inleiding 1

2 Dataverzameling 5

3 De keuze voor BOL, BBL of de arbeidsmarkt 9

3.1 Inleiding 9

3.2 Wie kiezen voor BOL, BBL of de arbeidsmarkt? 10

$\begin{array}{ll}3.3 \text { Keuzemotieven } & 12\end{array}$

3.4 Wat bepaalt de keuze om direct te gaan werken? 16

$\begin{array}{lll}3.5 \text { Conclusie } & 18\end{array}$

4 De school- en beroepsloopbaan 21

4.1 Inleiding 21

4.2 Gediplomeerden, overstappers, en afhakers 21

4.3 Analyse: wat bepaalt de kans om een diploma te halen? 23

$\begin{array}{ll}4.4 \text { De transitie van school naar werk } & 25\end{array}$

$\begin{array}{lll}4.5 \text { Conclusie } & 27\end{array}$

5 De huidige arbeidsmarktpositie $\quad 29$

$\begin{array}{ll}5.1 \text { Inleiding } & 29\end{array}$

5.2 Kenmerken van de (werk)situatie $\quad 29$

$\begin{array}{lll}5.3 \text { Aanvullende scholing } & 31\end{array}$

$\begin{array}{ll}5.4 \text { Beloning } & 32\end{array}$

$\begin{array}{lll}5.5 & \text { Conclusie } & 34\end{array}$

6 Evaluatie en toekomstverwachtingen $\quad 37$

$\begin{array}{ll}6.1 \text { Inleiding } & 37\end{array}$

6.2 Een evaluatie van de studie- en beroepskeuze 37

6.3 Evaluatie van competenties en toekomstverwachtingen 39

$\begin{array}{ll}6.4 \text { Conclusie } & 41\end{array}$

7 Conclusie $\quad 43$

$\begin{array}{ll}\text { Literatuur } & 47\end{array}$

Bijlage 1: De Wet Educatie en Beroepsonderwijs (WEB) 49

$\begin{array}{ll}\text { Bijlage 2: Vragenlijst } & 51\end{array}$

$\begin{array}{ll}\text { Bijlage 3: Aanvullende vragenlijst } & 69\end{array}$ 



\section{Resumé}

Schoolverlaters van het VBO en de MAVO staan, naast doorstroom in het algemeen voortgezet onderwijs, twee leerwegen open in het beroepsonderwijs: de beroepsopleidende en de beroepsbegeleidende leerweg. Daarnaast is het mogelijk dat de schoolverlaters de arbeidsmarkt betreden zonder verdere vorm van kwalificering. Uit maatschappelijk oogpunt wordt deze derde weg in het algemeen als ongewenst beschouwd en het overheidsbeleid is er dan ook in het bijzonder op gericht om deze jongeren alsnog een zogeheten startkwalificatie te laten behalen. Verwacht mag worden dat een goed inzicht in de gevolgen van een keuze voor de arbeidsmarkt, de beroepsopleidende leerweg of de beroepsbegeleidende leerweg pas na enkele jaren zichtbaar worden. Deze langere termijn effecten staan dan ook in dit rapport centraal.

Inzicht in de langere termijn effecten van deze keuzes is voor verscheidene beleidsterreinen relevant. Eerst en vooral geeft het een beeld van de efficiëntie van de beide leerwegen in het beroepsonderwijs. Een belangrijke meerwaarde ten opzichte van het reguliere schoolverlatersonderzoek, dat meer gericht is op de korte termijn effecten, is voorts dat meer zicht wordt verkregen op het intern rendement van beide leerwegen. In hoeverre verschilt de succeskans bij beide leerwegen, in welke mate switcht men van leerweg en waar komen de voortijdig uitvallers terecht? Bovendien wordt een vergelijking gemaakt met de groep die zich zonder startkwalificatie aanbiedt op de arbeidsmarkt. Dit vormt een ijkpunt voor het extern rendement van beide leerwegen in het beroepsonderwijs. Deze laatste vraag sluit duidelijk aan bij het arbeidsmarktbeleid dat er op is gericht iedereen een startkwalificatie te laten behalen voor toetreding tot de arbeidsmarkt.

De gegevens uit het onderzoek zijn ook van betekenis voor het arbeidsmarkt-, activerings- en scholingsbeleid ten aanzien van werklozen en werkenden. Het is met name interessant hoe de loopbanen van degenen die zonder startkwalificatie de arbeidsmarkt betreden, zich ontwikkelen. Volgen deze schoolverlaters nog één of andere vorm van aanvullende scholing. Geeft het werk waar ze terecht komen nog mogelijkheden om zich verder te ontplooien of zijn het vooral dead-end-jobs en blijven deze schoolverlaters tot de risicogroepen behoren?

De onderzoeksopzet was als volgt. Het ROA voert jaarlijks een schriftelijke enquête uit onder MAVO en VBO schoolverlaters anderhalf jaar na het verlaten van de opleiding. $\mathrm{Er}$ is onder schoolverlaters die in 1993/'94 en in 1994/'95 schriftelijk zijn geënquêteerd in 1999 telefonisch een vervolgmeting gehouden. Er zit tussen deze vervolgmeting en het moment van schoolverlaten circa vijf tot zeven jaar. In deze meting wordt ingegaan op de verdere school- en beroepsloopbaan van de schoolverlaters. Daarbij komen verschillende aspecten aan bod, zoals keuzemotieven om een vervolgopleiding te volgen of om direct te gaan werken. Ook is er uitgebreid ingegaan op de verschillende functies die men tot nu toe heeft bekleed. Voor het onderzoek zijn 3290 mensen benaderd. Uiteindelijk hebben 1617 mensen aan het onderzoek meegewerkt; dit is een respons van $49 \%$. Over het algemeen is de steekproef representatief naar geslacht, leeftijd en gekozen traject (BOL, BBL of arbeidsmarkt). 
Tijdens de eerste fase van de dataverzameling bleek dat respondenten met een BBL-opleiding, ondanks een relatief hoge respons, absoluut gezien ondervertegenwoordigd waren in de steekproef. Om toch verantwoorde uitspraken te kunnen doen over BBL'ers, is er destijds een aanvullende dataverzameling verricht die geheel gericht was op het verkrijgen van meer respondenten die voor een BBL-opleiding hadden gekozen. In deze aanvullende dataverzameling zijn uitsluitend mensen met een VBO-vooropleiding geënquêteerd. Uit de eerste dataverzameling bleek namelijk dat VBO'ers veel vaker voor een BBL-opleiding kozen dan MAVO-schoolverlaters. Door het vergroten van de respons van VBO'ers en daarmee van degenen die voor een BBL-opleiding kozen, kan meer zicht worden gekregen op hoe deze groep zich ontwikkelt in de loopbaan in verhouding tot scholieren die een BOL-opleiding hebben gevolgd.

Mannen kiezen eerder voor een BBL-opleiding dan vrouwen. In het BBL vormen mannen de meerderheid, terwijl in het BOL mannen en vrouwen elkaar in evenwicht houden. Met name VBO'ers kiezen ervoor om direct te gaan werken; MAVOleerlingen kiezen vaker voor een vervolgopleiding, met name in de beroepsopleidende leerweg. Direct werkenden beoordelen de studie- en beroepskeuzevoorlichting die zij hebben ontvangen even goed als degenen die een vervolgopleiding zijn gaan doen. Dit lijkt uit te sluiten dat zij wegens een gebrekkige studie- en beroepskeuzevoorlichting besluiten om direct de arbeidsmarkt te betreden. Eenvijfde van hen heeft alvorens de arbeidsmarkt te betreden toch nog overwogen om een opleiding te volgen. BOL'ers kiezen vaker hun opleiding uit toekomstgerichte overwegingen dan BBL'ers. Deze bevinding toont op zichzelf de relevantie van het aanbieden van zowel opleidingen via de beroepsopleidende als de beroepsbegeleidende leerweg aan.

Het overall-rendement van het middelbaar beroepsonderwijs bedraagt ruim $75 \%$. Ruim driekwart van de scholieren die aan een BOL- of BBL-opleiding begint, behaalt een diploma. Slechts ruim $20 \%$ van degenen die aan een middelbare beroepsopleiding zijn begonnen, verlaat zonder startkwalificatie het onderwijs. Het komt vaker voor dat scholieren die met een BBL-opleiding zijn gestart overstappen naar een BOL-opleiding en daar uiteindelijk een diploma van behalen dan andersom. Slechts $11 \%$ van de scholieren die na de MAVO of het VBO direct zijn gaan werken behaalt alsnog een startkwalificatie. Dit is meestal een BBL-diploma, hetgeen erop wijst dat een BBL-opleiding blijkbaar laagdrempeliger is voor scholieren die alsnog een startkwalificatie willen behalen dan een voltijdse BOL-opleiding. De stap naar de beroepsbegeleidende leerweg is voor deze groep kleiner dan naar de beroepsopleidende leerweg.

De kans om een diploma te behalen wordt voor een belangrijk deel bepaald door het type vervolgopleiding. Scholieren die een BBL-opleiding volgen, hebben een grotere kans om ongediplomeerd de opleiding te verlaten dan scholieren die een BOLopleiding volgen. Enerzijds bevinden zich juist onder scholieren van de BBLopleidingen relatief veel voortijdig schoolverlaters, anderzijds bieden deze opleidingen aan scholieren die direct zijn gaan werken de grootste kans om alsnog een startkwalificatie te behalen. 
De arbeidsmarktpositie van zowel BOL'ers, BBL'ers als mensen zonder startkwalificatie kan in 1999 over het algemeen als goed bestempeld worden. De werkloosheid is laag, velen hebben een vaste baan gevonden en de aansluiting tussen opleiding en beroepspraktijk is qua richting over het algemeen goed. BBL'ers verdienen op dit moment van de loopbaan beduidend meer dan zowel BOL'ers als respondenten zonder startkwalificatie, ook wanneer voor een aantal persoons- en baankenmerken gecorrigeerd wordt. De beloning van BOL'ers en respondenten zonder startkwalificatie ligt op een vergelijkbaar niveau. Enerzijds hebben BOL'ers een hoger kwalificatieniveau; anderzijds hebben zij veel minder werkervaring dan respondenten zonder startkwalificatie. Blijkbaar houden deze twee effecten elkaar op dit moment van de loopbaan min of meer in evenwicht.

De deelname aan aanvullende scholing naast het werk is relatief beperkt. Meer dan driekwart van de respondenten heeft na het verlaten van de opleiding geen aanvullende scholing meer gevolgd. Aan meer dan de helft van de scholingstrajecten of cursussen ligt het vergroten van de ontplooiingsmogelijkheden ten grondslag. Ongeveer $30 \%$ van de scholingstrajecten heeft het karakter van bijscholing in het kader van de huidige functie. Tussen de BOL'ers en BBL'ers zijn er opmerkelijk weinig verschillen. Dit zou kunnen betekenen dat de beroepsopleidende en de beroepsbegeleidende leerweg een ongeveer even goede voorbereiding op de beroepspraktijk bieden.

De meerderheid van de in 1999 onderzochte jongeren is tevreden met de gemaakte studie- en beroepskeuze direct na het schoolverlaten en zou weer opnieuw dezelfde opleiding of hetzelfde werk kiezen. Degenen die dit niet zouden geven vaker aan liever een BOL-opleiding te hebben gevolgd dan een BBL-opleiding. Relatief weinig jongeren die direct zijn gaan werken geeft aan achteraf liever een opleiding te hebben gevolgd. Hieruit kan geconcludeerd worden dat het scala aan mogelijkheden dat VBO- en MAVO-schoolverlaters geboden wordt, hen in staat stelt uiteindelijk een bevredigend traject te doorlopen.

Een vergelijking tussen BOL'ers, BBL'ers en respondenten zonder statkwalificatie ten aanzien van het competentieniveau is moeilijk. Het referentiekader verschilt immers tussen de drie groepen. BOL-gediplomeerden noemen vaker de vervolgopleiding als belangrijkste bron voor het verwerven van competenties, terwijl BBL-gediplomeerden vaker het werk noemen. Direct werkenden geven vaker aan hun competenties in de vooropleiding of ergens anders te hebben verworven. In het algemeen worden de meeste competenties in de vervolgopleiding of op het werk verworven. Deze bevindingen laten opnieuw zien dat de verschillende leerwegen een duidelijk te onderscheiden functie vervullen en een groot aantal VBO- en MAVO-schoolverlaters op verschillende manieren in staat stellen een startkwalificatie te behalen.

Bijna de helft van de ondervraagden is bereid om in de komende jaren langdurige scholing te volgen. Er is geen onderscheid in opleidingsbereidheid tussen BOL- of BBL-gediplomeerden en direct werkenden. Veruit de meerderheid van de respondenten denkt dat de belangrijkste bezigheid over vijf jaar betaald werk zal zijn. 
Concluderend kan gesteld worden dat investeren in het behalen van een startkwalificatie loont. BBL'ers verdienen beduidend meer dan arbeidskrachten zonder startkwalificatie. De beloning van BOL'ers blijft hier enigszins bij achter als gevolg van de geringere werkervaring. Uit eerder onderzoek is echter gebleken dat BOL'ers die achterstand op BBL'ers snel weten in te halen (Van der Velden en Lodder, 1995).

Ondanks het feit dat investeren in een BOL- of BBL-opleiding loont, blijken ook schoolverlaters van het VBO en de MAVO die gekozen hebben voor de arbeidsmarkt inmiddels een goede arbeidsmarktpositie te hebben verworven. Dit is opmerkelijk, gezien de ongunstige arbeidsmarktsituatie in het midden van de jaren '90. De respondenten zonder startkwalificatie blijken bovendien tevreden te zijn met hun situatie. Het aantal spijtoptanten van de keuze om geen startkwalificatie te verwerven is gering, men heeft het gevoel een goede studie- en beroepskeuzevoorlichting te hebben gehad en slechts weinigen besluiten alsnog een opleiding te volgen, hoewel de opleidingsbereidheid niet achterblijft bij die van middelbaar opgeleiden. Hieruit blijkt dat gediplomeerde schoolverlaters van het VBO en de MAVO die vervolgens voor de arbeidsmarkt kiezen zeker perspectief hebben op de arbeidsmarkt.

Ook degenen die gekozen hebben voor een BOL- of een BBL-opleiding kijken met een grote mate van tevredenheid terug. Het brede scala aan mogelijkheden dat de VBO'er en de MAVO-leerling ter beschikking staat leidt er blijkbaar toe dat een groot deel van hen een vervolgtraject kan kiezen dat bij hen past. Uiteindelijk weten BOL'ers en BBL'ers, ondanks de verschillende leerwegen waarin de accenten in de wijze van het verwerven van competenties verschillen, een vergelijkbare positie op de arbeidsmarkt te verwerven. Het competentieniveau lijkt elkaar niet veel te ontlopen, de behoefte aan bijscholing is vergelijkbaar en ook de arbeidsmarktpositie is voor beide leerwegen als goed te bestempelen. Al met al lijken de beroepsopleidende en de beroepsbegeleidende leerweg een ongeveer even goede voorbereiding op de beroepspraktijk te bieden.

Dit rapport doet verslag van een onderzoek dat primair tot doel had meer inzicht te verkrijgen in de lange termijn effecten van keuzes die schoolverlaters van het VBO en de MAVO maken. Het is belangrijk te benadrukken dat de in dit rapport gepresenteerde resultaten inzicht verschaffen in het extern rendement van de initiële opleidingskeuze en veel minder in het extern rendement van de opleidingen. Voor het adequaat meten van het extern rendement van opleidingen is een meting zo'n vijf jaar na het verlaten van de VBO- of MAVO-opleiding eigenlijk nog te vroeg. Het rapport heeft laten zien dat een groot deel van de respondenten de opleiding nog niet heeft afgerond. Bovendien bevinden de respondenten zich, onder meer afhankelijk van de keuze na het verlaten van het VBO of de MAVO, in een verschillende fase van de loopbaan, waardoor met name de werk- en praktijkervaring aanzienlijk kan verschillen. 


\section{Inleiding}

Schoolverlaters van het VBO en de MAVO staan, naast doorstroom in het algemeen voortgezet onderwijs, twee leerwegen open in het beroepsonderwijs: de beroepsopleidende en de beroepsbegeleidende leerweg. Daarnaast is het mogelijk dat de schoolverlaters de arbeidsmarkt betreden zonder verdere vorm van kwalificering. Uit maatschappelijk oogpunt wordt deze derde weg in het algemeen als ongewenst beschouwd en het overheidsbeleid is er dan ook in het bijzonder op gericht om deze jongeren alsnog een zogeheten startkwalificatie te laten behalen.

Het inzicht in de langere termijn effecten van de drie keuzes is relatief gering. Geeft de ene leerweg op termijn een hoger rendement dan de andere leerweg? Gaan schoolverlaters die direct de arbeidsmarkt betreden in een later stadium alsnog een startkwalificatie behalen? Het bestaande schoolverlatersonderzoek onder middelbaar opgeleiden richt zich vooral op de bestemming in het eerste jaar na het verlaten van de opleiding. Verwacht mag echter worden dat een goed inzicht in de gevolgen van een keuze voor de arbeidsmarkt, de beroepsopleidende leerweg of de beroepsbegeleidende leerweg) pas na enkele jaren zichtbaar worden. Deze langere termijn effecten van de keuzes die de schoolverlaters van het VBO en de MAVO maken staan dan ook in dit rapport centraal.

Inzicht in de langere termijn effecten van deze keuzes is voor verscheidene beleidsterreinen relevant. Eerst en vooral geeft het een beeld van de efficiëntie van de beide leerwegen in het beroepsonderwijs. Een belangrijke meerwaarde ten opzichte van het reguliere schoolverlatersonderzoek is voorts dat meer zicht wordt verkregen op het intern rendement van beide leerwegen. In hoeverre verschilt de succeskans bij beide leerwegen, in welke mate switcht men van leerweg en waar komen de voortijdig uitvallers terecht? Bovendien wordt een vergelijking gemaakt met de groep die zich zonder startkwalificatie aanbiedt op de arbeidsmarkt. Dit vormt een ijkpunt voor het extern rendement van beide leerwegen in het beroepsonderwijs.

Deze laatste vraag sluit duidelijk aan bij het arbeidsmarktbeleid dat er op is gericht iedereen een startkwalificatie te laten behalen voor toetreding tot de arbeidsmarkt. Onderzoek laat zien dat juist voor degenen aan de onderkant van de arbeidsmarkt de arbeidsmarktpositie het meest ongunstig is.

De gegevens uit het onderzoek zijn ook van betekenis voor het arbeidsmarkt-, activerings- en scholingsbeleid ten aanzien van werklozen en werkenden. Het is met name interessant hoe de loopbanen van degenen die zonder startkwalificatie de arbeidsmarkt betreden, zich ontwikkelen. Volgen deze schoolverlaters nog één of andere vorm van aanvullende scholing. Geeft het werk waar ze terecht komen nog mogelijkheden om zich verder te ontplooien of zijn het vooral dead-end-jobs en blijven deze schoolverlaters tot de risicogroepen behoren?

Dit onderzoek heeft betrekking op scholieren die in de eerste helft van de jaren negentig het VBO of de MAVO hebben verlaten. Dit was voor de invoering van WEB (Wet Educatie Beroepsonderwijs). In deze wet werd de herstructurering van het 
onderwijs in het BVE-veld een feit. Hierbij werd het systeem waarbij een onderscheid werd gemaakt tussen het (K)MBO als meer theoretische onderwijsvorm enerzijds en het leerlingwezen als meer praktijkgerichte vorm anderzijds getransformeerd tot een systeem waarbij de leerling twee leerwegen ter beschikking staan: de beroepsopleidende en de beroepsbegeleidende leerweg. In Bijlage 1 wordt een relatie gelegd tussen de oude opleidingsstructuur en de bijbehorende benamingen en de nieuwe kwalificatiestructuur zoals die is vastgelegd in de WEB. Hoewel dit onderzoek dus scholieren betreft die destijds de keuze hadden tussen het MBO en het leerlingwezen, is er toch voor gekozen de terminologie van de WEB te hanteren. Twee argumenten liggen hieraan ten grondslag. Ten eerste verhoogt het de vergelijkbaarheid met ander onderzoek. Ten tweede heeft een aanzienlijk deel van de respondenten later in opleiding in de nieuwe WEB-kwalificatiestructuur gevolgd.

De opzet van dit rapport is als volgt. Dit rapport is gebaseerd op onderzoeksresultaten die middels een speciaal voor dit onderzoek ontwikkelde telefonische vragenlijst zijn verkregen. In hoofdstuk 2 zal kort worden beschreven hoe de dataverzameling voor het onderzoek is verlopen. Er zal worden ingegaan op de representativiteit van de steekproef, alsmede op de samenstelling van de onderzoekspopulatie naar een aantal achtergrondkenmerken van de respondenten, zoals geslacht en leeftijd.

In hoofdstuk 3 staat de initiële keuze van MAVO- en VBO-scholieren ten aanzien van hun verdere school- en beroepsloopbaan centraal. Er wordt in dit hoofdstuk ingegaan op de achtergrondkenmerken van degenen die besluiten een BOL- of BBL-opleiding te volgen en degenen die besluiten om direct te gaan werken. Daarnaast wordt er ook gekeken naar de keuzemotieven voor een vervolgopleiding of voor betaald werk. Op die manier kan meer inzicht worden verkregen in de reden om door te leren of om te gaan werken. Er wordt ook aandacht besteed aan de studie- en beroepskeuzevoorlichting die de scholieren op de MAVO en het VBO hebben ontvangen.

In hoofdstuk 4 wordt dieper ingegaan op het verdere verloop van de school- en beroepsloopbaan. Er zal worden ingegaan op de factoren die het schoolsucces bepalen en hoe voortijdig uitvallers hun school- of beroepsloopbaan vervolgen. Bovendien wordt er in dit hoofdstuk gekeken naar de transitie van school naar werk. Daarbij wordt specifiek gekeken of er verschillen in de initiële arbeidsmarktpositie zijn tussen schoolverlaters met een BOL-opleiding als hoogst voltooide opleiding, BBL'ers en schoolverlaters zonder startkwalificatie.

Hoofdstuk 5 is gericht op het in kaart brengen van de huidige arbeidsmarktpositie, dat wil zeggen de arbeidsmarktpositie zo'n vijf jaar na het verlaten van de VBO- of MAVO-opleiding. Naast een schets van de arbeidsmarktpositie in relatie tot de hoogst voltooide opleiding, wordt dieper ingegaan op het functioneren in de baan. Er wordt daarbij gekeken naar de deelname aan aanvullende scholing. Deelname aan aanvullende scholing kan betekenen dat de in de initiële opleiding verworven kennis en vaardigheden niet volledig aansluiten op de in de baan vereiste kennis en vaardigheden. Het biedt ook een indicatie van de kansen en mogelijkheden op en buiten de arbeidsmarkt. Ten slotte kan aanvullende scholing een middel zijn om de 
loopbaan een geheel andere wending te geven. De scholing heeft in dit geval meer het karakter van omscholing. Ook de beloning geeft een goede indicatie van het functioneren in de baan. In hoofdstuk 5 wordt daarom tevens nagegaan welke arbeidskrachten in welke banen het best worden beloond.

In hoofdstuk 6 wordt zowel terug- als vooruitgeblikt. Op de eerste plaats wordt de studiekeuze van de onderzochte jongeren tegen het licht gehouden. Met deze eigen evaluatie van de destijds gemaakte keuze kan inzicht worden verkregen in de mate waarin jongeren via het onderwijs een voor hen geschikte opleiding gaan volgen en daarmee in de macrodoelmatigheid van het onderwijs. Er wordt tevens bekeken in hoeverre de gevolgde opleiding invloed heeft op waar en de mate waarin de jongeren competenties hebben verworven. Op die manier kan inzicht worden verkregen welke bijdrage de opleiding levert bij het verwerven van competenties. Tot slot wordt er ingegaan op de toekomstverwachtingen van de onderzochte jongeren. Het rapport wordt afgesloten met een conclusie.

De projectleiding van dit onderzoek was bij het ROA in handen van drs. P. van Eijs. Verder is bij het ROA aan dit onderzoek meegewerkt door drs. S. Farag, dr. R. van der Velden en $\mathrm{P}$. van der Kolk. De dataverzameling is uitgevoerd door DESAN Research Solutions. Bij DESAN is aan het onderzoek meegewerkt door drs. M. van Alphen en drs. J. Hartkamp Het onderzoek is verricht in opdracht van de Nederlandse Organisatie voor Wetenschappelijk Onderzoek (NWO), het Ministerie van Onderwijs, Cultuur en Wetenschappen (OCenW) en het Ministerie van Sociale Zaken en Werkgelegenheid (SZW). Onze dank gaat uit naar de leden van de begeleidingscommissie voor hun deskundige begeleiding: Van deze commissie hebben gedurende de uitvoering van het project de volgende personen deel utgemaakt: drs. P. Berendsen (NWO), drs. J. Donk (SZW), drs. M. Friesen (OcenW), drs. F. Straatjes (SZW), drs. U. Teunis (OcenW) en drs. B. Verlaan (OcenW). 



\section{Dataverzameling}

In dit hoofdstuk zal kort worden beschreven hoe de dataverzameling voor het onderzoek is verlopen. $\mathrm{Er}$ zal worden ingegaan op de representativiteit van de steekproef en op een aantal achtergrondkenmerken van de respondenten in de steekproef, zoals geslacht en leeftijd.

Het ROA voert jaarlijks een schriftelijke enquête uit onder MAVO en VBO schoolverlaters anderhalf jaar na het verlaten van de opleiding. In deze vragenlijst wordt onder meer ingegaan op de vooropleiding, de afgesloten opleiding, en de huidige maatschappelijke positie. Er is onder schoolverlaters die in 1993/'94 en in 1994/'95 schriftelijk zijn geënquêteerd in 1999 telefonisch een vervolgmeting gehouden. Er zit tussen deze vervolgmeting en het moment van schoolverlaten circa vijf tot zeven jaar. In deze meting wordt ingegaan op de verdere school- en beroepsloopbaan van de schoolverlaters. Daarbij komen verschillende aspecten aan bod, zoals keuzemotieven om een vervolgopleiding te volgen of om direct te gaan werken. Ook is er uitgebreid ingegaan op de verschillende functies die men tot nu toe heeft bekleed.

De vragenlijst is opgezet in zeven verschillende blokken, namelijk: een introductie en blokken met vragen over: de gevolgde BOL-opleiding, de gevolgde BBL-opleiding, betaald werk, werkloosheid en competenties en een blok met algemene afsluitende vragen. De opleidingsblokken en de blokken over betaald werk en werkloosheid konden maximaal drie keer worden doorlopen. Welke blokken worden doorlopen hangt af van wat de respondent na het schoolverlaten is gaan doen. Dit is voor iedereen verschillend. Het is bijvoorbeeld mogelijk dat iemand is begonnen aan een BBL-opleiding, maar halverwege is overgestapt naar een BOL-opleiding en daarna is gaan werken. Deze respondent doorloopt dan de blokken BBL, BOL en betaald werk. lemand die binnen een BOL-opleiding van studie is veranderd, doorloopt opnieuw een blok met vragen over de BOL-opleiding. Om te kunnen weten welke blokken een respondent moet doorlopen, is er aan het begin van de vragenlijst gevraagd om een chronologisch overzicht te geven van de activiteiten direct na het schoolverlaten. Op basis hiervan is een kalender ingevuld die vervolgens als leidraad dient voor het doorlopen van de verschillende blokken. Als men verschillende activiteiten combineert (bijvoorbeeld het volgen van een opleiding met betaald werk), dan zijn achtereenvolgens de bijbehorende blokken afzonderlijk doorlopen. De gemiddelde tijd die men nodig had om de vragen te beantwoorden was 25 minuten. In Bijlage 2 is de volledige vragenlijst terug te vinden.

De dataverzameling is als volgt verlopen. Van de 4710 mensen die potentieel konden worden benaderd, zijn 3290 mensen daadwerkelijk telefonisch benaderd. In de overige gevallen was de juiste persoon onbereikbaar, of was er sprake van een verkeerd telefoonnummer of een afgesloten telefoonnummer. Van deze 3290 hebben uiteindelijk 1617 mensen aan het onderzoek meegewerkt, dit is een respons van $49 \%$. De respons is vrijwel gelijk verdeeld over de verschillende groepen schoolverlaters, uitgesplitst naar de initiële opleidingskeuze na het verlaten van het VBO of 
de MAVO (zie tabel 2.1). De categorie overig ${ }^{1}$ heeft een iets lagere respons (44\%) in vergelijking met de overige categorieën (rond de 50\%). Een verdere uitsplitsing van de respons naar sekse en etniciteit laat zien dat er nauwelijks verschillen in de respons zijn tussen zowel mannen en vrouwen, als tussen allochtonen en autochtonen.

Tabel 2.1

Responspercentages uitgesplitst naar de status vooraf ${ }^{2}$

\begin{tabular}{lrrrc}
\hline & BOL & BBL & Overig & Onbekend \\
\hline Aantal benaderd & 2309 & 483 & 343 & 118 \\
Aantal meegewerkt & 1184 & 224 & 150 & 59 \\
Respons in \% & 51 & 46 & 44 & 50 \\
\hline
\end{tabular}

Tijdens de eerste fase van de dataverzameling bleek dat respondenten met een BBL-opleiding, ondanks een relatief hoge respons, absoluut gezien ondervertegenwoordigd waren in de steekproef. Om toch verantwoorde uitspraken te kunnen doen over BBL'ers, is er destijds een aanvullende dataverzameling verricht die geheel gericht was op het verkrijgen van meer respondenten die voor een BBLopleiding hadden gekozen. In deze aanvullende dataverzameling zijn uitsluitend mensen met een VBO-vooropleiding geënquêteerd. Uit de eerste dataverzameling bleek namelijk dat VBO'ers veel vaker voor een BBL-opleiding kozen dan MAVOschoolverlaters. Door het vergroten van de respons van VBO'ers en daarmee van degenen die voor een BBL-opleiding kozen, kan meer zicht worden gekregen op hoe deze groep zich ontwikkelt in de loopbaan in verhouding tot scholieren die een BOLopleiding hebben gevolgd. In Bijlage 3 is de aanvullende vragenlijst opgenomen.

De belangrijkste reden dat mensen niet aan het onderzoek hebben meegewerkt is omdat zij geen zin of tijd hadden. Er is geen verschil in non-respons tussen de verschillende groepen schoolverlaters (direct werkenden, BOL'ers, en BBL'ers). Er is tevens geen verschil in non-respons wat geslacht en etniciteit betreft. Van de 1617 respondenten konden uiteindelijk 1351 als werkbare cases in het databestand worden opgenomen. Van de overige respondenten waren te weinig gegevens beschikbaar.

Over het algemeen is de steekproef representatief naar geslacht, leeftijd, en etniciteit, evenals naar de verdeling $\mathrm{BOL} / \mathrm{BBL}^{3}$. In tabel 2.2 wordt een overzicht gepresenteerd van een aantal achtergrondkenmerken van de steekproefpopulatie. Daaruit blijkt dat er een gelijke man/vrouw verdeling in de steekproef is. Onder de

1. Onder de categorie 'overig' vallen respondenten die geen vervolgopleiding zijn gaan doen na het verlaten van de MAVO of het VBO.

2. Dit is de status die zij in de schriftelijke enquête hadden opgegeven anderhalf jaar na het schoolverlaten. Het is mogelijk dat men de opleiding uiteindelijk niet heeft afgemaakt en iets anders is gaan doen.

3. Om de representativiteit te bepalen is er gekeken naar de verdeling van deze variabelen bij de metingen van het ROA schoolverlatersonderzoek "Schoolverlaters tussen onderwijs en arbeidsmarkt". 
uitstroom van schoolverlaters van de BOL bevinden zich over het algemeen iets meer vrouwen dan mannen (57\%), terwijl bij de BBL-opleidingen er juist iets minder vrouwen te vinden zijn (40\%) (ROA, 1999, Statistische bijlage, blz. 4). Een gelijke man/vrouw verdeling in de steekproef komt derhalve redelijk overeen met de verdeling naar geslacht van de landelijke uitstroom ${ }^{4}$. De gemiddelde leeftijd is 22 jaar. Rond deze leeftijd hebben de meeste schoolverlaters een BOL-opleiding al afgerond. BBL'ers zijn rond deze leeftijd nog meestal in opleiding. Onder de schoolverlaters is $7 \%$ allochtoon. Dit komt redelijk overeen met het percentage allochtonen in de landelijke uitstroom van schoolverlaters.

De meerderheid (69\%) van de schoolverlaters in de steekproef heeft VBO als vooropleiding. Er zijn jaarlijks ongeveer evenveel schoolverlaters van de MAVO als van het VBO. Zoals gezegd is bewust voor deze oververtegenwoordiging van VBO'ers in de steekproef gekozen om het aantal BBL'ers op een representatief peil te brengen. Van de VBO'ers volgt gemiddeld $20 \%$ een BBL-opleiding, terwijl de rest een BOL-opleiding volgt (circa 60\%), of verder niet aan een kwalificerend vervolgtraject begint (circa 25\%). Van schoolverlaters met MAVO als vooropleiding volgt landelijk gezien nog geen tien procent een BBL-opleiding. De verdeling van de hoogst voltooide opleiding van de respondenten over de diverse opleidingssectoren, en over de diverse opleidingsniveaus komt overeen met landelijke beeld.

Bij de huidige maatschappelijke positie valt op, dat bijna $40 \%$ van de schoolverlaters nog een opleiding volgt. Dit is in de meeste gevallen een BOL-opleiding (32\%). Uit een nadere analyse blijkt, dat het hier voornamelijk schoolverlaters betreft die aan een tweede BOL-opleiding beginnen nadat ze de eerste BOL- of BBL-opleiding succesvol hebben afgesloten. Het is dus niet zo dat bijna de helft van de ondervraagden nog geen opleiding op MBO-niveau heeft afgerond. Op zich is het niet zo verwonderlijk dat een relatief hoog percentage van de schoolverlaters besluit een tweede opleiding te gaan volgen. Landelijk gezien gaat circa $40 \%$ van de gediplomeerden van een BOL-opleiding niveau 3 of niveau 4 een vervolgopleiding doen. Wel is het opvallend dat dit in het onderhavige onderzoek vaak een BOLopleiding is. Landelijk gezien betreft het meestal een HBO-opleiding. Bijna $60 \%$ van de schoolverlaters heeft op dit moment betaald werk. Dit percentage komt overeen met het landelijk percentage van gediplomeerden van een BOL-opleiding niveau 3 of niveau 4. Slechts $1 \%$ van de ondervraagde scholieren is werkloos. Dit duidt erop dat het niet moeilijk is om werk te vinden in deze tijden van een krappe arbeidsmarkt.

4. Overigens moet worden bedacht dat de landelijke uitstroomcijfers gebaseerd zijn op gediplomeerde schoolverlaters van BOL- en BBL-opleidingen, terwijl zich in de steekproef ook ongediplomeerde schoolverlaters bevinden. Dit kan enige afwijking van het landelijke beeld verklaren. 
Tabel 2.2

Kenmerken van de steekproefpopulatie

Geslacht (\%)

Man

50

Vrouw

Leeftijd (gemiddeld)

Etniciteit (\%)

Autochtoon

Allochtoon

Vooropleiding (\%)

VBO

MAVO

Hoogst voltooide opleiding (\%)

BOL

$\mathrm{BBL}$

Sector hoogst voltooide opleiding (\%)

Algemeen

Economie

Techniek

9

Landbouw

Gedrag en Maatschappij

Gezondheidszorg

11

16

Opleidingsniveau (\%)

Niveau $1 / 2$

Niveau 3/4

Huidige maatschappelijke positie (\%)

BOL

32

BBL

Betaald werk

Werkloos/werkzoekend

Overig $^{5}$

59

1

1

5. Onder overig valt: onbetaald werk, vakantie langer dan één maand, zorgtaken/huishouden, en de categorie anders. 


\section{De keuze voor BOL, BBL of de arbeidsmarkt}

\subsection{Inleiding}

In dit hoofdstuk staat de initiële keuze van MAVO- en-VBO scholieren ten aanzien van hun verdere school- en beroepsloopbaan centraal. Deze keuze kan verregaande gevolgen hebben voor de toekomstige loopbaan. Ten eerste is er de vraag of men wel of niet in verdere scholing zal investeren. Dit is bepalend voor het uiteindelijke kwalificatieniveau dat de scholieren behalen en waarmee ze de arbeidsmarkt betreden. Ten tweede kan men kiezen uit verdere scholing via de beroepsopleidende of de beroepsbegeleidende leerweg ${ }^{6}$. Een BOL-opleiding is een opleiding waarbij men minstens vier dagen per week naar school gaat, terwijl een BBL-opleiding leren en werken combineert. Meestal gaat men dan één dag per week naar school. Dergelijke keuzes worden meestal direct na het schoolverlaten van de MAVO of het VBO gemaakt en zijn van invloed op de latere arbeidsmarktpositie.

Met name de keuze voor wel of niet verder doorleren is maatschappelijk van belang, omdat degenen die niet doorleren geen startkwalificatie hebben verworven ${ }^{7}$. Hierdoor zijn zij op de arbeidsmarkt naar verwachting relatief kwetsbaar. Werkgevers blijken veelal op diploma's te selecteren vanwege het signaal dat deze afgeven over de bekwaamheid van een persoon en de verwachte trainingskosten. Hoe hoger het kwalificatieniveau, des te lager zijn deze kosten en dat is des te aantrekkelijker voor een werkgever ${ }^{8}$. Op de korte termijn kan het financieel voordelig zijn om direct te gaan werken, maar op de lange termijn verdient een investering in scholing zich uiteindelijk terug vanwege de hogere arbeidsproductiviteit die gekwalificeerde schoolverlaters hebben ten opzichte van ongekwalificeerde schoolverlaters. De gekwalificeerde schoolverlaters hebben meer kennis en vaardigheden opgedaan dan de schoolverlaters zonder startkwalificatie. Uit onderzoek blijkt, dat ongediplomeerde schoolverlaters een ongunstigere arbeidsmarktpositie hebben dan gediplomeerde schoolverlaters (ROA, 2000).

Er wordt in dit hoofdstuk ingegaan op de achtergrondkenmerken van degenen die na het afronden van de VBO- of MAVO-opleiding besluiten een BOL- of BBL-opleiding te volgen en degenen die besluiten om direct te gaan werken. Aan de hand van kenmerken als geslacht, leeftijd, etniciteit, het opleidingsniveau van de ouders, en de vooropleiding (MAVO of VBO) wordt bekeken welke groepen voor een BOL- dan wel BBL-opleiding kiezen, of voor het direct betreden van de arbeidsmarkt. Behalve naar de kenmerken van scholieren wordt er ook gekeken naar de keuzemotieven die zij noemen voor een vervolgopleiding of voor betaald werk. Op die manier kan meer inzicht worden verkregen in de reden om door te leren of om te gaan werken. Er wordt ook aandacht besteed aan de studie- en beroepskeuzevoorlichting die de scholieren op

6. Hoewel dit onderzoek scholieren betreft die destijds de keuze hadden tussen MBO en leerlingwezen, is er, zoals in de inleiding reeds werd aangegeven, toch voor gekozen om de terminologie van de WEB (Wet Educatie Beroepsonderwijs) te hanteren.

7. Men heeft een startkwalificatie als men een HAVO of VWO diploma, dan wel een BOL of BBL diploma niveau 2 behaalt.

8. Dit gegeven ligt ten grondslag aan de zogenaamde arbeidsrijtheorie (Thurow, 1975). 
de MAVO en het VBO hebben ontvangen. Er is gevraagd hoe goed zij deze voorlichting vonden. Dit is een concreet aanknopingspunt waar scholen hun beleid eventueel op zouden kunnen aanpassen. Tot slot wordt er gekeken wat de kans beïnvloedt om direct na het schoolverlaten betaald werk te verrichten. Een dergelijke analyse is van belang, omdat dan duidelijk wordt welke factoren mede bepalen dat scholieren na hun MAVO- of VBO- diploma geen startkwalificatie behalen.

\subsection{Wie kiezen voor BOL, BBL of de arbeidsmarkt?}

Tabel 3.1 geeft een eerste inzicht in de vraag welke groepen na het afronden de VBO- of MAVO-opleiding voor een BOL-opleiding, een BBL-opleiding of voor betaald werk kiezen. Van de 1351 ondervraagde respondenten is de meerderheid $(70 \%)$ direct na het schoolverlaten een BOL-opleiding gaan volgen, $16 \%$ is een BBLopleiding gaan doen, $11 \%$ is gaan werken, en $3 \%$ is iets anders gaan doen. De tabel laat zien dat ongeveer even veel mannen (48\%) als vrouwen voor een BOL-opleiding kiezen. Er lijkt derhalve geen samenhang met geslacht te zijn wat het kiezen van een BOL-opleiding betreft. Meer mannen (58\%) dan vrouwen kiezen voor een BBLopleiding. Van de direct werkenden is de verhouding man-vrouw nagenoeg gelijk, terwijl bij de categorie 'overig' meer vrouwen (58\%) dan mannen vertegenwoordigd zijn. Het betreft hierbij voor een belangrijk deel zorg- en huishoudelijke taken, die nog steeds voornamelijk door vrouwen worden verricht. Er is nagenoeg geen verschil in de gemiddelde leeftijd van de scholieren die een opleiding zijn gaan volgen en de scholieren die direct zijn gaan werken of iets anders zijn gaan doen. Dit kan te maken hebben met de relatief geringe spreiding in leeftijd voor de gehele onderzoeksgroep.

In het BOL $(8 \%)$ en onder de direct werkenden $(7 \%)$ lijken iets meer allochtonen $(8 \%)$ terug te vinden dan in de BBL-opleidingen (4\%). Van de direct werkenden is het leeuwendeel afkomstig uit het VBO (93\%). Ook onder BBL-opleidingen is het merendeel van de scholieren (89\%) van het VBO afkomstig. In de BOL-opleidingen is het percentage VBO'ers aanzienlijk lager (60\%). Deze cijfers geven aan, dat VBOscholieren meer op werken ingesteld zijn dan MAVO-scholieren. De gemiddelde studieduur van de vooropleiding verschilt nauwelijks tussen de verschillende groepen en bedraagt circa drie jaar.

De meest populaire opleidingssectoren zijn zowel in de BOL- als de BBL-opleidingen techniek en economie. Met name in de BBL is techniek erg populair. Van de BBL'ers volgt bijna de helft een techniekopleiding (44\%), tegenover ruim een kwart van de BOL'ers (27\%). Ongeveer een kwart van de scholieren volgt een economieopleiding. Eenvijfde van de BOL'ers kiest een algemene opleidingsrichting, terwijl dit onder BBL'ers nauwelijks voorkomt door het praktijkgerichte karakter van de opleiding. Er is een duidelijk verschil in startniveau te zien tussen degenen die aan een BOLopleiding beginnen (69\% op niveau $3 / 4$ ) en degenen die aan een BBL-opleiding beginnen (58\% op niveau $3 / 4)$. 
Tabel 3.1

Achtergrondkenmerken van schoolverlaters VBO/MAVO die direct na het schoolverlaten voor $\mathrm{BOL}, \mathrm{BBL}$, betaald werk, of overig ${ }^{9}$ kiezen

\begin{tabular}{|c|c|c|c|c|}
\hline & BOL & BBL & $\begin{array}{c}\text { Direct } \\
\text { werkenden }\end{array}$ & Overig \\
\hline \multicolumn{5}{|l|}{ Geslacht (\%) } \\
\hline Man & 48 & 58 & 51 & 42 \\
\hline Vrouw & 52 & 42 & 49 & 58 \\
\hline Leeftijd (gemiddeld) & 18 & 18 & 18 & 18 \\
\hline \multicolumn{5}{|l|}{ Etniciteit (\%) } \\
\hline Autochtoon & 92 & 96 & 93 & 91 \\
\hline Allochtoon & 8 & 4 & 7 & 9 \\
\hline \multicolumn{5}{|l|}{ Vooropleiding (\%) } \\
\hline VBO & 60 & 89 & 93 & 74 \\
\hline MAVO & 40 & 11 & 7 & 26 \\
\hline \multicolumn{5}{|l|}{ Studieduur vooropleiding } \\
\hline \multicolumn{5}{|l|}{ Opleidingssector } \\
\hline Algemeen & 21 & 3 & - & - \\
\hline Economie & 23 & 25 & - & - \\
\hline Techniek & 27 & 44 & - & - \\
\hline Landbouw & 8 & 9 & - & - \\
\hline Gedrag en Maatschappij & 9 & 3 & - & - \\
\hline Gezondheidszorg & 12 & 16 & - & - \\
\hline \multicolumn{5}{|l|}{ Opleidingsniveau } \\
\hline Niveau $1 / 2$ & 31 & 42 & - & - \\
\hline Niveau 3/4 & 69 & 58 & - & - \\
\hline \multicolumn{5}{|c|}{ Opleidingsniveau Vader ${ }^{10}(\%)$} \\
\hline $\operatorname{Laag}^{11}$ & 48 & 60 & 62 & 45 \\
\hline Middelbaar & 32 & 31 & 31 & 29 \\
\hline Hoog & 20 & 9 & 7 & 26 \\
\hline \multicolumn{5}{|c|}{ Opleidingsniveau Moeder (\%) } \\
\hline Laag & 67 & 82 & 75 & 73 \\
\hline Middelbaar & 24 & 13 & 21 & 17 \\
\hline Hoog & 9 & 5 & 4 & 10 \\
\hline \multirow[t]{2}{*}{$\mathrm{N}$} & 939 & 218 & 151 & 43 \\
\hline & $\begin{array}{l}100 \% \\
(70 \%)\end{array}$ & $\begin{array}{l}100 \% \\
(16 \%)\end{array}$ & $\begin{array}{l}100 \% \\
(11 \%)\end{array}$ & $\begin{array}{c}100 \% \\
(3 \%)\end{array}$ \\
\hline
\end{tabular}

9. In de categorie 'overig' valt: onbetaald werk, werkloos/werkzoekend, vakantie langer dan 1 maand, zorgtaken/huishouden, en anders namelijk.

10. De $\mathrm{N}$ bij de opleiding van de ouders is een kwart lager dan de oorspronkelijke $\mathrm{N}$, respectievelijk 701, 152, 98, en 31 voor de opleiding van de vader. De percentages van de opleiding van de moeder zijn eveneens op dergelijke aantallen gebaseerd.

11. Laag = lagere school, lagere beroepsopleiding, MAVO/MULO;

Middelbaar = HAVO/MMS, VWO/HBS/Gymnasium, MBO;

$\mathrm{Hoog}=\mathrm{HBO}$, Universiteit. 
Het milieu van herkomst kan van invloed zijn op de keuze voor een bepaald type vervolgopleiding of om te gaan werken. Dit is gemeten aan de hand van het opleidingsniveau van de ouders. De verwachting is dat relatief laaggeschoolde ouders wellicht minder waarde aan een vervolgdiploma hechten en dat derhalve hun kinderen sneller direct gaan werken. Voor scholieren die een BOL-opleiding gaan volgen lijkt dit het geval te zijn; zij hebben vaker hoger opgeleide vaders dan de scholieren die direct gaan werken ( $20 \%$ versus $7 \%$ ). Dit is echter niet het geval bij de scholieren die een BBL-opleiding gaan doen. De verdeling van het opleidingsniveau van de vader is bij hen vrijwel dezelfde als bij de scholieren die direct gaan werken. De moeders zijn over het algemeen minder hoog geschoold dan de vaders, maar desalniettemin is ook bij hen hetzelfde patroon zichtbaar, namelijk dat een hoog opleidingsniveau van de ouder relatief vaak samengaat met het volgen van een BOLopleiding door het kind. Dit suggereert dat het zogenoemde sociaal kapitaal dat kinderen van huis uit meekrijgen (bijvoorbeeld in de vorm van zekere normen en waarden, of interesse voor scholing) van invloed is op de keuze die zij maken ten aanzien van hun verdere school- en beroepsloopbaan. De volgende kanttekening is hier echter op zijn plaats: er zijn meer laagopgeleide moeders onder de scholieren die een BBL-opleiding gaan volgen dan onder de scholieren die direct gaan werken. Een mogelijk effect van diverse factoren (waaronder het opleidingsniveau van de ouders) op de kans om direct na het schoolverlaten te gaan werken, wordt in paragraaf vier behandeld.

Aangezien vrouwen en allochtonen speerpunten vormen in het overheidsbeleid, is het interessant om te kijken naar de keuzes die deze groepen maken na het verlaten van de VBO- of MAVO-opleiding. Tabel 3.2 laat zien dat 19\% van de mannen voor een BBL-opleiding kiest. Dit hangt mede samen met het feit dat BBL-opleidingen met name in de techniek erg populair zijn. Bij de vrouwen is dit slechts $14 \%$. Vrouwen blijken wat vaker voor een BOL-opleiding te kiezen. Uit tabel 3.2 blijkt tevens dat allochtonen relatief vaak $(77 \%)$ voor een $\mathrm{BOL}$-opleiding kiezen.

Tabel 3.2

Relatie tussen geslacht en etniciteit en trajectkeuze

\begin{tabular}{lrrrrr}
\hline in $\%$ & Man & Vrouw & Autochtoon & Allochtoon & Totaal \\
\hline BOL & 67 & 72 & 69 & 77 & 70 \\
BBL & 19 & 14 & 17 & 9 & 16 \\
werk & 11 & 11 & 11 & 10 & 11 \\
overig & 3 & 4 & 3 & 4 & 3 \\
\hline
\end{tabular}

\subsection{Keuzemotieven}

In deze paragraaf wordt nader ingegaan op de keuzemotieven die de scholieren zelf noemen om na het afronden van de VBO- of MAVO-opleiding een vervolgopleiding te gaan doen of om direct te gaan werken. Hiermee kan inzicht worden gekregen in wat nu doorslaggevende factoren zijn geweest in het keuzeproces. 
$\mathrm{Er}$ is aan de respondenten gevraagd wat zij van de studie- en beroepskeuzevoorlichting vonden die zij op school hebben gehad. Dit kan van invloed zijn geweest op de keuzemotieven van scholieren voor een bepaalde vervolgopleiding of betaald werk. Rond de $70 \%$ van hen geeft aan dat de voorlichting voldoende of goed was. Dit percentage verschilt niet tussen degenen die een BOL- of BBL-opleiding zijn gaan doen, of betaald werk. Dit houdt in, dat degenen die direct zijn gaan werken na het schoolverlaten even tevreden zijn over de studievoorlichting als degenen die een vervolgopleiding zijn gaan doen. Vooralsnog lijkt dit uit te sluiten dat direct werkenden wegens een gebrekkige studie- en beroepskeuzevoorlichting besluiten om de arbeidsmarkt te betreden. Men is voldoende op de hoogte welke kansen en mogelijkheden het middelbaar beroepsonderwijs biedt.

Er is tevens aan de respondenten gevraagd of men nog andere bezigheden heeft overwogen alvorens te kiezen voor een vervolgopleiding of direct werken (zie tabellen 3.3 tot en met 3.5). Hieruit komt naar voren dat verreweg de meerderheid van degenen die een BOL-opleiding gaan doen geen andere bezigheden heeft overwogen (90\%). Van degenen die een BBL-opleiding zijn gaan doen heeft $82 \%$ geen andere bezigheden overwogen. Van de BBL'ers heeft $8 \%$ overwogen om direct te gaan werken en eveneens $8 \%$ heeft overwogen een voltijd opleiding te gaan volgen. Van degenen die direct zijn gaan werken heeft $77 \%$ geen andere bezigheden overwogen, terwijl $14 \%$ een BBL-opleiding heeft overwogen en $7 \%$ een voltijd opleiding. Uit deze cijfers blijkt, dat eenvijfde van degenen die uiteindelijk direct na het schoolverlaten zijn gaan werken, toch nog hebben overwogen om een opleiding te volgen. Wellicht zou een inspanning van de scholen deze relatief grote groep twijfelaars alsnog over de streep kunnen trekken om een vervolgopleiding te gaan doen. Hiermee zou het aantal voortijdig schoolverlaters dat ongekwalificeerd de arbeidsmarkt betreedt gereduceerd kunnen worden.

Tabel 3.3

Andere bezigheden overwogen door BOL'ers

\begin{tabular}{lr}
\hline in $\%$ & BOL \\
\hline Nee & 90 \\
Ja, direct gaan werken & 5 \\
Ja, een BBL-opleiding & 3 \\
Ja, anders & 2 \\
\hline
\end{tabular}

Tabel 3.4

Andere bezigheden overwogen door BBL'ers

\begin{tabular}{lr}
\hline in \% & BBL \\
\hline Nee & 82 \\
Ja, direct gaan werken & 8 \\
Ja, een BOL-opleiding & 8 \\
Ja, anders & 2 \\
\hline
\end{tabular}


Tabel 3.5

Andere bezigheden overwogen door direct werkenden

\begin{tabular}{lc}
\hline in \% & Direct werkenden \\
\hline Nee & 77 \\
Ja, een voltijd opleiding & 7 \\
Ja, een BBL-opleiding & 14 \\
Ja, anders & 1 \\
\hline
\end{tabular}

In tabel 3.6 tot en met tabel 3.8 is beschreven wat de uiteindelijke keuzemotieven waren voor scholieren om respectievelijk een BOL-opleiding te volgen, een BBLopleiding te volgen, en om direct te gaan werken. Het belangrijkste keuzemotief dat genoemd wordt om een BOL-opleiding te gaan doen, is dat je later meer kunt verdienen als je doorleert (28\%). Andere belangrijke motieven die genoemd worden, zijn: een interessante opleiding (22\%), en dat deze opleiding nodig was voor het beroep dat men later wilde uitoefenen (23\%). De laatste twee keuzemotieven zijn ook belangrijk voor scholieren die een BBL-opleiding gaan volgen. Zij geven echter vaker als keuzemotief aan een opleiding interessant te vinden (20\%) dan dat de opleiding nodig was voor het toekomstige beroep (14\%). Het belangrijkste keuzemotief voor scholieren die een BBL-opleiding zijn gaan doen, is dat zij de combinatie werken en leren aantrekkelijk vonden (29\%).

Opvallend weinig scholieren geven aan dat ze een BBL-opleiding zijn gaan doen omdat ze dan later meer kunnen verdienen (8\%). Dit is een groot contrast met scholieren die vaak juist om deze reden een BOL-opleiding zijn gaan volgen. De grotere nadruk die deze scholieren hierop leggen, evenals op het nut van de opleiding voor het uit te oefenen beroep, duiden op een grotere toekomstgerichtheid van scholieren die een BOL-opleiding gaan volgen in vergelijking met scholieren die een BBL-opleiding gaan doen. Het percentage BBL'ers dat eigenlijk wilde werken, maar geen baan kon vinden is daarentegen erg gering (1\%). Bij zowel BOL'ers als BBL'ers noemt ongeveer $20 \%$ interesse voor de opleiding als keuzemotief. Samenvattend kiezen BOL'ers vaker hun opleiding uit toekomstgerichte overwegingen dan BBL'ers. Deze bevinding toont op zichzelf de relevantie van het aanbieden van zowel opleidingen via de beroepsopleidende als de beroepsbegeleidende leerweg aan.

Tabel 3.6

Belangrijkste keuzemotief van schoolverlaters voor BOL

in $\% \quad$ BOL

Interessante opleiding $\quad 22$

Deze opleiding was nodig voor het beroep dat ik wilde 23

Geen interessant werk

Mijn ouders leek het beter om door te leren

Beter om door te leren zodat je later meer kunt verdienen

Ik kon makkelijk leren

Ik was nog (gedeeltelijk) leerplichtig

In het regulier voortgezet onderwijs kon ik geen examen doen

Anders 
Tabel 3.7

Belangrijkste keuzemotief van schoolverlaters voor BBL

in $\% \quad$ BBL

Interessante opleiding

$B L$

Deze opleiding was nodig voor het beroep dat ik wilde

Er was geen voltijd opleiding die me interesseerde 4

Mijn ouders leek het beter om naar de BBL te gaan 0

Geen interessant werk

Beter om door te leren zodat je later meer kunt verdienen

Misschien zou ik geen diploma van een voltijd opleiding kunnen halen

Ik was nog (gedeeltelijk) leerplichtig

Mijn werkgever wilde dat ik deze opleiding ging volgen

Combinatie leren en werken aantrekkelijk

Ik wilde eigenlijk werken, maar kon geen baan vinden

Anders

20
14
4
0
0
8
0
8
1
29
1
15

Voor eenderde van de scholieren die direct na het schoolverlaten zijn gaan werken, is het feit dat ze dan meteen geld konden verdienen het belangrijkste keuzemotief geweest. Eenvijfde van hen kreeg interessant werk aangeboden. Dat er verder geen interessante opleidingen waren is eveneens een belangrijk keuzemotief om direct te gaan werken (15\%). Deze groep zou, middels het aanbieden van een breder palet aan opleidingen wellicht over de streep getrokken kunnen worden om een startkwalificatie te behalen. Opvallend is het geringe percentage scholieren $(2 \%)$ dat eigenlijk liever een BBL-opleiding had willen volgen, maar geen geschikte leerarbeidsplaats kon vinden. In de discussie over de beschikbaarheid van leerarbeidsplaatsen wordt een geringe beschikbaarheid van deze plaatsen vaak als mogelijke reden genoemd waarom scholieren dan maar gaan werken. Dit blijkt echter erg mee te vallen.

Tabel 3.8

Belangrijkste keuzemotief van schoolverlaters om direct te gaan werken

in \% Direct werkenden

Ik kreeg interessant werk aangeboden

Voor het beroep dat ik wilde had ik geen opleiding meer nodig

Geen interessante opleiding

Mijn ouders leek het beter om te gaan werken

Met werken kon ik gelijk gaan verdienen

Misschien zou ik geen diploma van een opleiding kunnen halen

Ik was niet meer leerplichtig

Mijn werkgever wilde niet dat ik een BBL-opleiding zou volgen

Ik wilde BBL, maar ik kon geen geschikte leer-arbeidsplaats vinden

Anders

21

15

1

31

2

2

0

25

De bovenstaande keuzemotieven kan men clusteren in zogeheten push en pull factoren. Push factoren zijn afstootmechanismen die buiten de intrinsieke motivatie van het individu liggen, terwijl pull factoren aantrekkingsmechanismen zijn die veelal binnen de intrinsieke motivatie van het individu liggen. Een voorbeeld van een push factor is dat iemand een opleiding gaat doen omdat hij of zij nog leerplichtig is. Een voorbeeld van een pull factor is dat iemand een opleiding gaat doen omdat hij of zij 
deze opleiding interessant vindt. Het criterium voor het onderscheid in push dan wel pull factor ligt in deze definitie besloten in de eigen motivatie van het individu en is niet afhankelijk van de keuze die wordt gemaakt voor een vervolgopleiding of voor direct werken. Een push factor wordt ook vaak gezien als een afstootmechanisme uit het onderwijs en een pull factor als een aantrekkingsmechanisme naar de arbeidsmarkt toe (Portengen \& Dekkers, 1998).

Als we de vaakst genoemde keuzemotieven opnieuw bekijken, dan valt op dat pull factoren overheersen in de keuze voor een vervolgopleiding. BOL'ers geven vaker aan een opleiding interessant te vinden of nodig te hebben voor het beroep dat zij later willen uitoefenen, dan dat zij een opleiding kiezen omdat er verder geen interessant werk voorhanden was. Hetzelfde geldt voor BBL'ers. Van degenen die direct zijn gaan werken na het schoolverlaten geeft bijna eenvijfde (15\%) als reden hiervoor aan dat zij geen interessante opleiding konden vinden, hetgeen een push factor is. Bij direct werkenden is er daarom vaker sprake van een push factor dan bij degenen die een vervolgopleiding zijn gaan doen.

Tot slot kan ook nog worden gekeken naar de slagingskans die men voor zichzelf ziet bij het kiezen voor een vervolgopleiding of betaald werk (bijvoorbeeld "ik kon makkelijk leren" versus "ik wist niet zeker of ik een diploma zou kunnen halen"). Uit de cijfers blijkt (zie tabel 3.3 tot en met tabel 3.5), dat men zich slechts in geringe mate laat leiden door de slagingskans die men percipieert en eerder door pull factoren. Hierbij dient echter wel de kanttekening te worden gemaakt dat deze zaken heel waarschijnlijk met elkaar samenhangen en een onderscheid hierin nogal kunstmatig is. Waarschijnlijk begint men aan een opleiding als men daar ook een zekere kans van slagen voor zichzelf in ziet.

\subsection{Wat bepaalt de keuze om direct te gaan werken?}

Direct gaan werken na het behalen van een MAVO- of VBO-diploma wordt van beleidswege als ongewenst beschouwd, omdat het de verdere ontwikkeling van de loopbaan kan belemmeren. Hierbij is de gedachte dat iedere schoolverlater minimaal een startkwalificatie dient te hebben alvorens de arbeidsmarkt te betreden, hetgeen gunstig is voor zijn of haar arbeidsmarktpositie. Om meer inzicht te krijgen in welke factoren de keuze bepalen om direct te gaan werken, is er een logistische regressieanalyse uitgevoerd. In deze logistische regressie wordt gepoogd de kans om direct te kiezen voor de arbeidsmarkt te verklaren middels een aantal persoons-, achtergronden opleidingskenmerken. De resultaten hiervan zijn weergegeven in tabel 3.9.

Zowel geslacht als leeftijd hebben geen significante invloed op de kans om direct na het schoolverlaten te gaan werken. Mannen hebben een even grote kans om direct te gaan werken als vrouwen. Relatief jongere schoolverlaters hebben een even grote kans om direct te gaan werken als oudere schoolverlaters. Het meest in het oog springende verschil uit tabel 3.1 is dat voornamelijk VBO-scholieren direct gaan werken. Dit blijkt ook uit de analyse; MAVO-scholieren hebben significant minder kans om direct te gaan werken dan VBO-scholieren. Het blijft bij dit effect van vooropleiding op de kans om direct betaald werk te verrichten. Alle andere factoren 
oefenen hierop geen significante invloed uit. Er is niet veel variatie in studieduur of de mening over studievoorlichting, hetgeen wellicht het uitblijven van effecten hiervan op direct werken verklaart. Ook sociale herkomst gemeten aan de hand van het opleidingsniveau van de ouders heeft geen significant effect op de kans om direct na het schoolverlaten te gaan werken.

Tabel 3.9

De invloed van persoons- en studiekenmerken op de kans om direct na het schoolverlaten betaald werk te verrichten

\begin{tabular}{|c|c|}
\hline Variabele & B \\
\hline \multicolumn{2}{|l|}{ Geslacht } \\
\hline Man & referentie \\
\hline Vrouw & 0,090 \\
\hline Leeftijd & 0,108 \\
\hline \multicolumn{2}{|l|}{ Etniciteit } \\
\hline Autochtoon & referentie \\
\hline Allochtoon & $-0,561$ \\
\hline \multicolumn{2}{|l|}{ Vooropleiding } \\
\hline VBO & referentie \\
\hline MAVO & $-1,650^{* *}$ \\
\hline Studieduur vooropleiding & 0,357 \\
\hline Studievoorlichting (1=goed) & 0,133 \\
\hline \multicolumn{2}{|l|}{ Opleidingsniveau vader } \\
\hline Laag & referentie \\
\hline Midden & $-0,541$ \\
\hline Hoog & $-0,959$ \\
\hline \multicolumn{2}{|l|}{ Opleidingsniveau moeder } \\
\hline Laag & referentie \\
\hline Midden & 0,167 \\
\hline Hoog & $-0,210$ \\
\hline Constante & $-4,163$ \\
\hline Psuedo $\mathrm{R}^{2}$ & 0,096 \\
\hline Model $\mathrm{Chi}^{2}$ & $48,925^{\star *}$ \\
\hline Vrijheidsgraden & 10 \\
\hline $\mathrm{N}$ & 982 \\
\hline
\end{tabular}

* = significant op $5 \%$-niveau

** $=$ significant op $1 \%$-niveau

Omdat sociale herkomst wellicht wel van invloed is op welke vooropleiding men kiest, is er een additionele analyse uitgevoerd naar wat bepaalt of men een MAVO- of een VBO-vooropleiding kiest. In deze logistische regressie wordt gepoogd de kans om te kiezen voor een MAVO-opleiding te verklaren middels dezelfde persoons-, en achtergrondkenmerken als in de voorgaande analyse. De resultaten zijn weergegeven in tabel 3.10. Hieruit blijkt dat sociale herkomst er wel degelijk toe doet: kinderen van ouders met een middelbaar of hoger opleidingsniveau gaan significant 
vaker naar de MAVO dan kinderen van ouders met een lager opleidingsniveau. We kunnen hieruit concluderen dat sociale herkomst weliswaar geen direct effect heeft op de beslissing om na het verlaten van de vooropleiding te gaan werken, of verder te studeren. Er is echter wel sprake van een indirect effect via de vooropleiding.

Tabel 3.10

De invloed van persoonskenmerken en sociale herkomst om MAVO als vooropleiding te gaan doen

\begin{tabular}{lc}
\hline Variabele & B \\
\hline Geslacht & referentie \\
Man & 0,090 \\
Vrouw & $-0,541^{* *}$ \\
Leeftijd & \\
Etniciteit & referentie \\
Autochtoon & $0,489^{*}$ \\
Allochtoon & \\
Opleidingsniveau vader & referentie \\
Laag & $0,471^{* *}$ \\
Midden & $0,787^{* *}$ \\
Hoog & \\
Opleidingsniveau moeder & referentie \\
Laag & $0,358^{*}$ \\
Midden & $0,749^{* *}$ \\
Hoog & $10,766^{* *}$ \\
Constante & 0,123 \\
Psuedo $\mathrm{R}^{2}$ & $121,471^{* *}$ \\
Model Chi & 7 \\
Vrijheidsgraden & 1324 \\
$\mathrm{~N}$ & \\
\hline
\end{tabular}

* = significant op 5\%-niveau

** $=$ significant op $1 \%$-niveau

\subsection{Conclusie}

Het doel van dit hoofdstuk is om een beeld te schetsen van degenen die een BOLopleiding, een BBL-opleiding, of voor de arbeidsmarkt kiezen, welke keuzemotieven hierbij een rol spelen, en wat de kans beïnvloedt om direct te gaan werken na het schoolverlaten.

Ongeveer evenveel mannen als vrouwen kiezen na het afronden van de VBO- of MAVO-opleiding voor een BOL-opleiding of gaan direct werken, terwijl meer mannen dan vrouwen voor een BBL-opleiding kiezen. Allochtonen kiezen relatief vaak voor een BOL-opleiding. VBO-scholieren zijn meer ingesteld op werken dan MAVOscholieren, getuige hun relatief forse aandeel onder de direct werkenden en de BBL'ers, vergeleken met het aandeel onder de BOL'ers. Direct werkenden beoordelen de studie- en beroepskeuzevoorlichting die zij hebben ontvangen even 
goed als degenen die een vervolgopleiding zijn gaan doen. Dit lijkt uit te sluiten dat zij wegens een gebrekkige studie- en beroepskeuzevoorlichting besluiten om direct de arbeidsmarkt te betreden. Men is voldoende op de hoogte welke kansen en mogelijkheden het middelbaar beroepsonderwijs biedt. Eenvijfde van degenen die kiezen voor de arbeidsmarkt heeft nog overwogen om een opleiding te volgen. Wellicht zou een inspanning van de scholen (bijvoorbeeld door het aanbieden van een breder palet aan opleidingen) deze relatief grote groep twijfelaars alsnog over de streep kunnen trekken toch een startkwalificatie te behalen. BOL'ers kiezen vaker hun opleiding uit toekomstgerichte overwegingen dan BBL'ers. Deze bevinding toont op zichzelf de relevantie van het aanbieden van zowel opleidingen via de beroepsopleidende als de beroepsbegeleidende leerweg aan. Bij zowel BOL'ers als BBL'ers noemt ongeveer $20 \%$ interesse voor de opleiding als keuzemotief. Dit is een pull factor. Bij direct werkenden is er vaker sprake van een push factor als keuzemotief dan bij degenen die een vervolgopleiding zijn gaan doen.

De vooropleiding van scholieren is van invloed op hun kans om direct na het schoolverlaten te gaan werken. MAVO scholieren hebben significant minder kans hierop dan VBO scholieren. Het milieu van herkomst is indirect van invloed op de keuze om direct na het schoolverlaten te gaan werken. Hoe lager het opleidingsniveau van de ouders, des te groter is de kans dat men ongekwalificeerd de arbeidsmarkt betreedt. Dit effect loopt via de vooropleiding: kinderen van ouders met een middelbaar of hoog opleidingsniveau gaan significant vaker naar de MAVO dan kinderen van ouders met een laag opleidingsniveau. 



\section{De school- en beroepsloopbaan}

\subsection{Inleiding}

Hoe ontwikkelt zich de verdere school- en beroepsloopbaan van scholieren na het verlaten van de MAVO en het VBO? Deze vraag staat in dit hoofdstuk centraal. Er zal worden ingegaan op het aantal schoolverlaters dat een diploma behaalt, het aantal dat afhaakt, en het aantal dat overstapt naar een andere opleiding. Van degenen die tussentijds naar een andere opleiding overstappen zal worden bekeken of zij een diploma behalen. Vervolgens wordt geanalyseerd wat de kans beïnvloedt om een diploma te halen. Zeker in het kader van het reduceren van het aantal voortijdig schoolverlaters is deze analyse relevant. Uit onderzoek is namelijk gebleken dat voortijdige schooluitval een negatief effect heeft op de arbeidsmarktpositie (ROA, 2001). Het is daarom interessant om de mogelijke oorzaken van voortijdige schooluitval te achterhalen. Tot slot wordt er in dit hoofdstuk ook gekeken naar de transitie van school naar werk. Enkele kernindicatoren van de eerste baan zullen hierbij worden beschreven, zoals het type aanstelling en het netto uurloon. Daarbij wordt gekeken of er verschillen in de initiële arbeidsmarktpositie zijn tussen BOLgediplomeerden, BBL-gediplomeerden, en ongediplomeerden ${ }^{12}$.

\subsection{Gediplomeerden, overstappers, en afhakers}

Hoeveel scholieren die aan een BOL- of BBL-opleiding beginnen, behalen ook daadwerkelijk een diploma? Volgen scholieren die direct na de MAVO of het VBO zijn gaan werken, alsnog een vervolgopleiding? In tabel 4.1 wordt onder meer over deze zaken gerapporteerd. In deze tabel wordt een vergelijking gemaakt tussen de initiële keuze en het huidig kwalificatieniveau. Het gaat in deze tabel alleen om degenen die thans geen student meer $z_{i j n}{ }^{13}$. De tabel laat zien dat ruim driekwart van de scholieren die aan een BOL- of BBL-opleiding beginnen en thans het onderwijs heeft verlaten, een diploma heeft behaalt. Het resterende percentage van de scholieren haakt af en betreedt ongediplomeerd de arbeidsmarkt of houdt zich met andere activiteiten bezig, zoals het huishouden of onbetaald werk. In het algemeen ligt de voortijdige schooluitval onder BBL'ers iets hoger (22\%) dan onder BOL'ers $(20 \%)$. Scholieren die met een BBL-opleiding zijn gestart betreden iets vaker ongediplomeerd de arbeidsmarkt (15\%) dan scholieren die met een BOL-opleiding zijn gestart (11\%).

Scholieren kunnen van type leerweg (BOL of BBL) wisselen als de eerstgekozen opleiding ze niet zo goed bevalt. Het komt vaker voor (10\%) dat scholieren die met een BBL-opleiding zijn gestart overstappen naar een BOL-opleiding en daar uiteindelijk een diploma van behalen dan andersom. Slechts twee procent van degenen die aan een BOL-opleiding zijn begonnen stapt over naar een BBL-

12. Met ongediplomeerden worden hier schoolverlaters bedoeld die geen startkwalificatie hebben behaald omdat zij na de MAVO of het VBO geen vervolgopleiding zijn gaan doen.

13. Uit tabel 2.2 bleek dat liefst $39 \%$ van de respondenten thans nog steeds studeert. Het grootste deel (32\%) volgt een BOL-opleiding; de rest $(7 \%)$ een BBL-opleiding. 
opleiding en behaalt daarvan het diploma. $\mathrm{Er}$ is dan ook een aanzienlijk verschil tussen BOL'ers en BBL'ers wat betreft het afmaken van de opleiding waar men als eerste aan begonnen is. Van degenen die met een BBL-opleiding starten, behaalt $68 \%$ ook daadwerkelijk een BBL-diploma, terwijl van degenen die met een BOLopleiding starten $77 \%$ een BOL-diploma behaalt.

De ruime meerderheid (80\%) van de scholieren die direct na de MAVO of het VBO betaald werk is gaan doen, blijft dit uiteindelijk doen, al dan niet na pogingen om een vervolgopleiding succesvol te volgen. Slechts $11 \%$ behaalt alsnog een diploma. In de meeste gevallen is dit een BBL-diploma. Dit geeft aan dat BBL-opleidingen met name voor hen die alsnog een diploma willen behalen als een soort vangnet zouden kunnen werken. Door zijn duale structuur (een combinatie van werken en leren) is de opleiding blijkbaar makkelijker toegankelijk voor scholieren die alsnog een startkwalificatie willen behalen dan een voltijdse BOL-opleiding. Hier zou in het beleid om elke scholier een startkwalificatie te laten behalen rekening mee kunnen worden gehouden.

Van de scholieren die eerst iets anders zijn gaan doen, behaalt uiteindelijk $71 \%$ een diploma $^{14}$. Dit is meestal een BOL-diploma. Eenvijfde van de scholieren die met overige activiteiten zijn gestart betreedt ongediplomeerd de arbeidsmarkt. In totaal blijft bijna eenderde van deze scholieren ongediplomeerd.

Tabel 4.1

Overstappen naar BOL, BBL, arbeidsmarkt en overig

\begin{tabular}{lcccc}
\hline in \% & $\begin{array}{c}\text { BOL } \\
\text { diploma }\end{array}$ & $\begin{array}{c}\text { BBL } \\
\text { diploma }\end{array}$ & $\begin{array}{c}\text { Ongediplomeerd } \\
\text { Arbeidsmarkt }\end{array}$ & $\begin{array}{c}\text { Ongediplomeerd } \\
\text { Overig }\end{array}$ \\
\hline Gestart met BOL & 77 & 2 & 11 & 9 \\
Gestart met BBL & 10 & 68 & 15 & 7 \\
$\begin{array}{l}\text { Gestart met direct werken } \\
\text { Gestart met overige }\end{array}$ & 4 & 7 & 80 & 9 \\
activiteiten $^{15}$ & 57 & 14 & 20 & 9 \\
\hline
\end{tabular}

Er zijn 218 respondenten die ongediplomeerd hun eerste opleiding verlaten. Dit is $15 \%$ van de het totaal aantal respondenten dat na het verlaten van de VBO- of MAVO-opleiding aan een opleiding begint. Hiervan besluit circa de helft om aan een andere opleiding te beginnen. In tabel 4.2 staat weergegeven hoe het hen dan verder vergaat en of ze er in de tweede opleiding wél in slagen een diploma te halen.

De tabel laat zien dat het merendeel van de respondenten die hun eerste BOLopleiding ongediplomeerd verlaten opnieuw voor een BOL-opleiding kiest. Het komt niet zo vaak voor dat iemand van een BOL-opleiding naar een BBL-opleiding overstapt (10\%). Ondanks het stroeve begin, haalt de meerderheid alsnog een diploma. Van degenen die de eerste BOL-opleiding voortijdig afbraken behaalt $72 \%$

14. Hieronder vallen bijvoorbeeld ook vakanties van langer dan één maand.

15. Hieronder vallen activiteiten zoals: onbetaald werk, werkloos/werkzoekend, vakantie langer dan één maand, en zorgtaken/huishouden. 
alsnog een BOL-diploma en 4\% een BBL-diploma. Bijna een kwart (22\%) verlaat ongediplomeerd het onderwijs. Aangezien de cijfers over BBL'ers betrekking hebben op een klein aantal respondenten kan over hen niet veel met zekerheid worden gezegd. Het lijkt er niettemin op, dat BBL'ers vaker overstappen naar een BOLopleiding dan BOL'ers naar een BBL-opleiding.

Tabel 4.2

Overstappers tussen en binnen BOL- en BBL-opleidingen

\begin{tabular}{lccccc}
\hline & \multicolumn{2}{c}{ Gediplomeerd } & & \multicolumn{2}{c}{ Ongediplomeerd } \\
\cline { 2 - 3 } \cline { 5 - 6 } Eerste opleiding & BOL & BBL & & BOL & BBL \\
\hline BOL $^{16}$ & 72 & 4 & & 18 & 6 \\
BBL $^{16}$ & 33 & 33 & & 20 & 13 \\
\hline
\end{tabular}

\subsection{Analyse: wat bepaalt de kans om een diploma te halen?}

Uit eerder onderzoek blijkt dat ongediplomeerden vaak een slechtere arbeidsmarktpositie hebben in vergelijking met gediplomeerden. Dit komt onder meer tot uitdrukking in een lager bruto uurloon, minder kans op een vaste aanstelling en minder kans op een voltijd baan. Het is derhalve van belang voor de toekomstige arbeidsmarktpositie van schoolverlaters dat zij een diploma behalen. Uit eerder onderzoek blijkt dat factoren zoals geslacht en etniciteit van invloed zijn op de kans om een diploma te halen (ROA, 2001). Mannen en allochtonen lopen relatief meer risico om ongediplomeerd een opleiding te verlaten dan vrouwen en autochtonen. Ook leeftijd is van invloed: hoe jonger de scholier, des te groter is de kans op voortijdige schooluitval.

In de analyse naar de kans om een diploma te halen is er behalve naar de bovengenoemde factoren ook gekeken naar kenmerken van de vooropleiding en de vervolgopleiding. Bij kenmerken van de vooropleiding staat centraal of een scholier de MAVO of het VBO heeft gedaan, en wat de studieduur hiervan was. Bij kenmerken van de opleiding wordt gekeken of men aan een BOL- of aan een BBL-opleiding is begonnen en wat men van de studiebegeleiding in deze opleiding vond. Er is tenslotte eveneens rekening gehouden met het sociale milieu van herkomst van de scholieren. Dit is gedaan door te kijken naar het opleidingsniveau van de ouders.

De resultaten van de logistische regressieanalyse worden gepresenteerd in tabel 4.3. Uit de analyse blijkt dat de kans om een diploma te behalen voornamelijk door twee factoren wordt bepaald: het type vervolgopleiding en de studiebegeleiding op school. Scholieren die een BBL-opleiding volgen, hebben een grotere kans om ongediplomeerd de opleiding te verlaten dan scholieren die een BOL-opleiding volgen. Verder blijkt, dat hoe beter men de studiebegeleiding op school vindt, des te groter de kans is dat men gediplomeerd de opleiding verlaat. Opmerkelijk genoeg oefenen

16. Deze percentages hebben betrekking op slechts 15 respondenten. Bij de BOL'ers zijn de percentages gebaseerd op 82 respondenten. 
andere factoren geen significante invloed uit op de kans om een diploma te behalen. Hieruit kan vooralsnog worden geconcludeerd dat vooropleiding en de studieduur niet significant van invloed zijn op de kans om een diploma te behalen.

Tabel 4.3

Logistische regressie analyse van de kans om een diploma te halen ${ }^{17}$

\begin{tabular}{|c|c|}
\hline Variabele & B \\
\hline \multicolumn{2}{|l|}{ Geslacht } \\
\hline Man & referentie \\
\hline Vrouw & 0,089 \\
\hline Leeftijd & $-0,046$ \\
\hline \multicolumn{2}{|l|}{ Etniciteit } \\
\hline Autochtoon & referentie \\
\hline Allochtoon & $-0,438$ \\
\hline \multicolumn{2}{|l|}{ Vooropleiding } \\
\hline VBO & referentie \\
\hline MAVO & 0,196 \\
\hline Studieduur vooropleiding & 0,014 \\
\hline \multicolumn{2}{|l|}{ Opleiding } \\
\hline $\mathrm{BOL}$ & referentie \\
\hline $\mathrm{BBL}$ & $-0,668^{\star *}$ \\
\hline \multicolumn{2}{|l|}{ Studiebegeleiding } \\
\hline Matig/slecht & referentie \\
\hline Voldoende/goed & $0,750^{* *}$ \\
\hline \multicolumn{2}{|l|}{ Opleidingsniveau vader } \\
\hline Laag & referentie \\
\hline Midden & 0,390 \\
\hline Hoog & 0,187 \\
\hline \multicolumn{2}{|l|}{ Opleidingsniveau moeder } \\
\hline Laag & referentie \\
\hline Midden & $-0,448$ \\
\hline Hoog & $-0,284$ \\
\hline Constante & 2,116 \\
\hline Psuedo $\mathrm{R}^{2}$ & 0,074 \\
\hline Model Chi ${ }^{2}$ & $32,326^{* *}$ \\
\hline Vrijheidsgraden & 11 \\
\hline $\mathrm{N}$ & 829 \\
\hline
\end{tabular}

* = significant op 5\%-niveau

** $=$ significant op $1 \%$-niveau

Ook het sociale milieu van herkomst lijkt geen invloed te hebben op de slagingskans. Het lijkt erop dat de opleidingskenmerken van scholieren belangrijker zijn voor het behalen van een diploma dan hun persoonskenmerken of achtergrondkenmerken zoals het opleidingsniveau van de ouders. Het ontbreken van een significant effect

17. $0=$ ongediplomeerd, $1=$ gediplomeerd. 
van vooropleiding op de kans om een diploma te halen kan samenhangen met het feit dat vooropleiding sterk correleert met het type vervolgopleiding. Scholieren met VBO als vooropleiding kiezen vaak voor een BBL-opleiding, terwijl scholieren die de MAVO hebben gedaan vaker voor een BOL-opleiding kiezen. In tegenstelling tot eerder onderzoek heeft ook leeftijd geen positief significant effect. Dit zou te maken kunnen hebben met het feit dat het onderzoek betrekking heeft op leerlingen wiens leerplicht tijdens de onderzoeksperiode eindigt. Hoe hoger de leeftijd, hoe eerder die leerplicht eindigt en hoe groter de kans dat men eerder de opleiding verlaat.

\subsection{De transitie van school naar werk}

In deze paragraaf staat de transitie van school naar werk centraal. Er wordt een beeld hiervan geschetst aan de hand van gegevens over het aantal scholieren dat aan een tweede vervolgopleiding begint, het gemiddelde aantal banen dat men heeft gehad, en diverse kenmerken van de eerste baan. In deze paragraaf wordt, in tegenstelling tot de vorige paragrafen, de hoogste opleiding als uitgangspunt genomen. Er wordt een onderscheid gemaakt tussen drie groepen: (1) zij die een BOL-opleiding als hoogste opleiding hebben voltooid, (2) zij die een BBL-opleiding hebben afgerond en (3) zij die slechts een VBO- of MAVO-diploma hebben (de ongediplomeerden). Het betreft hier opnieuw de respondenten die het onderwijs op het moment van enquêteren verlaten hebben.

Bijna de helft van de respondenten die thans geen opleiding volgen heeft tot nu toe één baan gehad. Circa eenvijfde van de respondenten is al in twee of meer betaalde banen werkzaam geweest. BBL'ers hebben vaker meer banen gehad dan BOL'ers. Ook ongediplomeerden hebben vaak al meerdere betaalde banen gehad. Van de scholieren die reeds een BOL-diploma hebben behaald, verricht het merendeel betaald werk. Hetzelfde geldt voor BBL'ers. Er is nauwelijks sprake van intredewerkloosheid voor zowel gediplomeerde als ongediplomeerde schoolverlaters. Van de ongediplomeerden is twee procent werkloos, terwijl slechts één procent van de schoolverlaters met een BOL- of BBL-diploma een aantal maanden werkloos is tot zijn eerste baan. Dit is opmerkelijk aangezien met name voor de schoolverlaters zonder startkwalificatie de arbeidsmarkt halverwege de jaren '90 absoluut niet gunstig was.

Tabel 4.4 geeft een overzicht van de wijze waarop de respondenten hun eerste baan hebben verworven. Uit de tabel blijkt dat het uitzendbureau, de open sollicitatie, de stage, de personeelsadvertentie en de informele route via familie, vrienden of kennissen de belangrijkste kanalen zijn waarlangs de eerste baan wordt verworven. De tabel laat verder enkele opvallende verschillen tussen de drie groepen zien. Het is niet verrassend dat BBL'ers hun eerste baan veel vaker via school verwerven dan BOL'ers en mensen zonder startkwalificatie. Het zal hier in veel gevallen een aanstelling bij het leerbedrijf betreffen ${ }^{18}$. Opvallend is het geringe aantal BBL'ers dat via een uitzendbureau aan de slag gaat. Blijkbaar stelt de tijdens de opleiding

18. Mogelijk doet zich hier het probleem voor dat BBL'ers moeite hebben een onderscheid te maken tussen de opleiding (de leer- arbeidsplaats) en betaald werk. 
opgedane werkervaring hen beter in staat zonder bemiddeling werk te vinden. Ongediplomeerden, dat wil zeggen mensen zonder startkwalificatie, vinden veel minder vaak werk via een stage. Dit is niet verrassend, aangezien het hier veel een deel MAVO-schoolverlaters betreft.

Tabel 4.4

Het vinden van de eerste baan

\begin{tabular}{lccc}
\hline & BOL (\%) & BBL (\%) & Ongediplomeerd (\%) \\
\hline Via arbeidsbureau & 6 & 5 & 9 \\
Via uitzendbureau of commercieel & 19 & 4 & 20 \\
$\quad$ bemiddelingsbureau & 13 & 15 & 13 \\
Gereageerd op advertentie & 16 & 17 & 16 \\
Via open sollicitatie & 21 & 18 & 11 \\
Via stage & 6 & 14 & 4 \\
Via school & 0 & 1 & 0 \\
Via bedrijveninformatiedagen, & 4 & 6 & 5 \\
$\quad$ banenmarkt of open dag bedrijf & 16 & 16 & 16 \\
Via eerder werk, interne vacature & - & 2 & 1 \\
Via familie, vrienden of kennissen & - & - & 1 \\
Eigen bedrijf of praktijk begonnen & 2 & 4 & 3 \\
Bedrijf of praktijk overgenomen & 100 & 100 & 100 \\
Anders & & & \\
Totaal & &
\end{tabular}

In tabel 4.5 staan de kenmerken weergegeven van de eerste betaalde baan van de scholieren. BBL'ers (74\%) hebben veel vaker een vaste aanstelling dan BOL'ers $(52 \%)$, maar omgekeerd hebben BOL'ers (74\%) vaker een voltijdbaan dan BBL'ers $(63 \%)$. Ongediplomeerden hebben vaker een voltijdbaan dan BOL'ers en vaker een vaste aanstelling dan BBL'ers. Dit laatste is opmerkelijk, aangezien zij zich ten tijde van hun eerste baan nog niet langer op de arbeidsmarkt bevinden dan degenen die een vervolgopleiding zijn gaan doen en derhalve nog niet hebben kunnen profiteren van een langere verblijfstijd op de arbeidsmarkt. Zij hebben echter wel relatief het laagste bruto uurloon (12,28 gulden). BBL'ers verdienen meer (13,04 gulden) dan BOL'ers (12,62 gulden). De werkervaring die BBL'ers tijdens de opleiding hebben opgedaan wordt blijkbaar door de werkgever gewaardeerd en beloond. De tabel laat tevens zien dat een opvallend groot deel van de BBL'ers aangeeft beneden zijn of haar niveau werkzaam te zijn. Dit is een, ook uit eerder onderzoek, bekend resultaat. Vaak blijken BBL'ers het baanniveau echter te onderschatten en zijn zij toch op MBO-niveau werkzaam. Aangezien dit deels te maken heeft met de enigszins onduidelijke scheiding tussen opleiding en betaald werk bij BBL'ers kan ook het percentage vast werk enigszins onderschat worden.

Zowel BOL'ers als BBL'ers vinden in hun eerste baan vaak werk binnen de eigen opleidingsrichting (ca. 80\%). Ongediplomeerden hebben minder vaak werk in hun opleidingsrichting (66\%). Dit kan te maken hebben met het feit dat het hier deels mensen met een MAVO-diploma betreft. Aangezien de MAVO een algemene opleiding is, is het veel lastiger een duidelijk afgebakend beroependomein en daarmee 'werk in eigen richting' te definiëren. 
Tabel 4.5

Kenmerken van de eerste baan

\begin{tabular}{lccc}
\hline & BOL & BBL & Ongediplomeerd \\
\hline Vaste aanstelling (\%) & 52 & 74 & 60 \\
Voltijdbaan (\%) & 74 & 63 & 71 \\
Bruto uurloon (guldens) & 12,62 & 13,04 & 12,28 \\
standaarddeviatie bruto uurloon & 3,2 & 3,0 & 3,0 \\
Aansluiting opl.-werk (\%) op niveau ${ }^{19}$ & 66 & 38 & 64 \\
Binnen eigen richting & 81 & 86 & 66 \\
\hline
\end{tabular}

\subsection{Conclusie}

De verdere schoolloopbaan van scholieren na het verlaten van de MAVO en het VBO ontwikkelt zich als volgt. Het overall-rendement van het middelbaar beroepsonderwijs bedraagt ruim $75 \%$. Ruim driekwart van de scholieren die aan een BOL- of BBL-opleiding begint, behaalt een diploma. Slechts ruim $20 \%$ van degenen die aan een middelbare beroepsopleiding zijn begonnen, verlaat zonder startkwalificatie het onderwijs. Het komt vaker voor dat scholieren die met een BBL-opleiding zijn gestart overstappen naar een BOL-opleiding en daar uiteindelijk een diploma van behalen dan andersom. Slechts $11 \%$ van de scholieren die na de MAVO of het VBO direct zijn gaan werken behaalt alsnog een startkwalificatie. Dit is meestal een BBLdiploma, hetgeen erop wijst dat een BBL-opleiding blijkbaar laagdrempeliger is voor scholieren die alsnog een startkwalificatie willen behalen dan een voltijdse BOLopleiding. De stap naar de beroepsbegeleidende leerweg is voor deze groep kleiner dan naar de beroepsopleidende leerweg.

De kans om een diploma te behalen wordt voor een belangrijk deel bepaald door het type vervolgopleiding. Scholieren die een BBL-opleiding volgen, hebben een grotere kans om ongediplomeerd de opleiding te verlaten dan scholieren die een BOLopleiding volgen. Enerzijds bevinden zich juist onder scholieren van de BBLopleidingen relatief veel voortijdig schoolverlaters, anderzijds bieden deze opleidingen aan scholieren die direct zijn gaan werken de grootste kans om alsnog een startkwalificatie te behalen.

Over de transitie van school naar werk kan worden opgemerkt dat er nauwelijks sprake is van intredewerkloosheid onder de scholieren. Gemiddeld heeft men tot nu toe één betaalde baan gehad. Van degene die besluiten niet verder te studeren; verricht het merendeel betaald werk. Wat de kenmerken van de eerste baan betreft, hebben BBL'ers veel vaker een vaste aanstelling dan BOL'ers, maar omgekeerd hebben BOL'ers vaker een voltijdbaan dan BBL'ers. BBL'ers verdienen meer dan BOL'ers. De werkervaring die BBL'ers tijdens de opleiding hebben opgedaan wordt blijkbaar door de werkgever gewaardeerd en beloond.

19. In de categorie "op niveau" vallen ook degenen die boven hun opleidingsniveau werken. 



\section{De huidige arbeidsmarktpositie}

\subsection{Inleiding}

Een belangrijke exponent van het rendement van een opleidingskeuze is de huidige arbeidsmarktpositie. De huidige arbeidsmarktpositie, dat wil zeggen de arbeidsmarktpositie zo'n vijf jaar na het verlaten van de VBO- of MAVO-opleiding, staat in dit hoofdstuk centraal. In paragraaf 2 wordt de arbeidsmarktpositie geschetst aan de hand van een aantal indicatoren, zoals de arbeidsmarktstatus, de aard van de aanstelling en de inhoudelijke aansluiting tussen opleiding en beroepspraktijk. In de paragrafen 3 en 4 wordt dieper ingegaan op het functioneren in de baan. In paragraaf 3 staat scholing centraal. Het volgen van aanvullende scholing geeft een indicatie van het functioneren op de arbeidsmarkt. Het volgen van aanvullende scholing kan betekenen dat de in de initiële opleiding verworven kennis en vaardigheden niet volledig aansluiten op de in de baan vereiste kennis en vaardigheden. Het biedt ook een indicatie van de kansen en mogelijkheden op en buiten de arbeidsmarkt. Aanvullende scholing kan immers ook een opstap zijn naar een (betere) baan bij dezelfde of een andere werkgever. Ten slotte kan aanvullende scholing een middel zijn om de loopbaan een geheel andere wending te geven. De scholing heeft in dit geval meer het karakter van omscholing. Om een goed zicht te kunnen krijgen op het karakter van de scholing wordt in paragraaf 3 daarom niet alleen gekeken naar de mate waarin er aanvullende scholingstrajecten gevolgd worden, maar ook naar de belangrijkste redenen voor het verwerven van additionele kennis en vaardigheden. In paragraaf 4 staat de beloning centraal. De beloning geeft een goede indicatie van het functioneren in de baan. Om na te gaan welke arbeidskrachten in welke banen het best worden beloond, is een loonvergelijking geschat waarin de logaritme van het bruto uurloon wordt verklaard in een lineaire vergelijking op basis van een aantal baan- en persoonskenmerken. Het hoofdstuk wordt in paragraaf 5 afgesloten met een conclusie.

\subsection{Kenmerken van de (werk)situatie}

In deze paragraaf staat een aantal kenmerken van de huidige arbeidsmarktsituatie centraal. Het startpunt vormt een overzicht van de arbeidsmarktpositie. Vervolgens wordt de werksituatie belicht aan de hand van de volgende baankenmerken: de aard van de aanstelling, het aantal uren dat men werkt en de aansluiting tussen opleiding en beroepspraktijk naar niveau en richting. De nadruk hierbij ligt steeds op de drie groepen die in dit rapport centraal staan: de BOL'ers, de BBL'ers en de respondenten die geen startkwalificatie hebben behaald.

$\mathrm{Er}$ is aan de respondenten gevraagd om zelf hun situatie te typeren Het betreft hier dus een eigen inschatting van de respondenten ten aanzien van de bezigheden die hun situatie op het moment van enquêteren het beste weergeeft. Tabel 5.1 laat zien dat bijna $60 \%$ van de respondenten betaald werk heeft. Het is niet verrassend dat dit percentage het hoogst is bij degenen die meteen zijn gaan werken. Een opvallend groot percentage beschouwt zichzelf nog steeds als student. Maar liefst bijna de helft van de respondenten (ruim 46\%) die reeds een BOL-diploma hebben behaald geeft 
aan de studie nog steeds als hoofdactiviteit te beschouwen. Bij de BBL'ers is dat ruim $30 \%$. Ten slotte valt op dat de werkloosheid zeer gering is en dat de verschillen in werkloosheid tussen de BOL'ers, BBL'ers en respondenten zonder startkwalificatie verwaarloosbaar zijn.

Tabel 5.1

Huidige arbeidsmarktstatus naar hoogst voltooide opleiding in procenten

\begin{tabular}{lrrrr}
\hline & BOL & BBL & VBO-MAVO & Totaal \\
\hline Betaald werk & 52,6 & 66,7 & 68,9 & 59,4 \\
Opleiding & 46,6 & 30,6 & 27,8 & 38,9 \\
Werkloos & 0,4 & 0,5 & 1,5 & 0,7 \\
Overig & 0,4 & 2,2 & 1,8 & 1,0 \\
\hline
\end{tabular}

In tabel 5.2 wordt een overzicht gegeven van een aantal indicatoren voor de arbeidsmarktpositie van betaald werkenden: het hebben van een vaste baan, het hebben van een voltijds aanstelling en de aansluiting tussen opleiding en beroepspraktijk naar niveau en richting. Een vaste aanstelling is onder meer een indicator voor zekerheid. Tabel 5.2 laat zien dat ongeveer tweederde van de respondenten met betaald werk een vaste baan heeft. De verschillen tussen de drie groepen zijn relatief gering. BBL'ers hebben wat vaker een vaste baan dan BOL'ers. Dit is niet zo verrassend, aangezien BBL'ers over het algemeen al wat meer werkervaring hebben en in de huidige krappe arbeidsmarkt vaker bij het leerbedrijf kunnen blijven.

Tabel 5.2 laat tevens zien in hoeverre de respondenten een voltijds aanstelling hebben. Uit de tabel blijkt dat bijna $70 \%$ van de betaald werkenden meer dan 32 uur werkt. Opvallend is dat dit percentage voor BBL'ers aanzienlijk lager is.

Tabel 5.2

Indicatoren voor de arbeidsmarktpositie van betaald werkenden naar hoogst voltooide opleiding in procenten

\begin{tabular}{lcccc}
\hline & BOL & BBL & VBO-MAVO & Totaal \\
\hline Vaste baan & 59,4 & 73,9 & 69,7 & 64,8 \\
Voltijds aanstelling & 73,0 & 75,5 & 68,1 & 69,0 \\
Goede aansluiting naar niveau & 70,7 & 38,5 & 64,8 & 64,5 \\
Goede aansluiting naar richting & 80,0 & 83,3 & 63,2 & 76,1 \\
\hline
\end{tabular}

Een belangrijke maatstaf voor de kwaliteit van het werk en de arbeidsmarktpositie die men heeft weten te verwerven is de mate waarin het werk aansluit op het opleidingsniveau. Hoe beter de aansluiting, hoe beter de arbeidsmarktpositie. De tabel laat opmerkelijke verschillen zien. BOL'ers vinden vaak qua niveau passend werk. Ruim $70 \%$ heeft een baan op niveau gevonden. Ook respondenten zonder startkwalificatie vinden vaak een baan op niveau. Daarbij dient opgemerkt te worden dat dat voor hen een baan onder het MBO-niveau betreft. BBL'ers lijken grote moeite te hebben een baan op niveau te verwerven. Dit is een, ook uit eerder onderzoek, bekend resultaat. Vaak blijken BBL'ers het baanniveau echter te onderschatten en 
zijn zij toch op MBO-niveau werkzaam. Aangezien dit deels te maken heeft met de enigszins onduidelijke scheiding tussen opleiding en betaald werk bij BBL'ers kan bijvoorbeeld ook het percentage met een voltijds aanstelling enigszins onderschat worden.

Een tweede aspect van de aansluitingsproblematiek tussen opleiding en beroepspraktijk wordt gevormd door de vraag in hoeverre de baan aansluit bij de opleidingsrichting. Ook het al dan niet kunnen toepassen van de in de opleiding verworven kennis en vaardigheden is een belangrijke maatstafvoor de kwaliteit van het werk en van de arbeidsmarktpositie. Uit tabel 5.2 blijkt dat meer dan $75 \%$ van de respondenten een baan heeft gevonden die qua richting goed aansluit bij de gevolgde opleidingsrichting. De verschillen tussen BOL'ers en BBL'ers zijn gering. De respondenten zonder startkwalificatie hebben duidelijk meer moeite ondervonden bij het vinden van een baan in de eigen richting. Dit kan te maken hebben met het feit dat het hier deels mensen met een MAVO-diploma betreft. Aangezien de MAVO een algemene opleiding is, is het veel lastiger een duidelijk afgebakend beroependomein en daarmee 'werk in eigen richting' te definiëren.

\subsection{Aanvullende scholing}

Tegenwoordig is het vrij gebruikelijk om na het verlaten van het initieel onderwijs nog een opleiding of cursus te volgen. Tabel 5.1 liet al zien dat veel middelbaar opgeleiden ervoor kiezen om verder te studeren. Maar hoe zit dat met de respondenten die thans een betaalde baan hebben? In hoeverre hebben zij aan aanvullende scholingstrajecten deelgenomen? Uit tabel 5.3 blijkt dat de deelname aan aanvullende scholing relatief beperkt is. Meer dan driekwart van de respondenten heeft na het verlaten van de opleiding geen aanvullende scholing meer gevolgd. Slechts zo'n $6 \%$ van de respondenten geeft aan meer dan één aanvullend scholingstraject of cursus gevolgd te hebben. De tabel laat tevens zien dat de verschillen tussen de drie groepen gering zijn. Het volgen van een aanvullend scholingstraject kan een indicator zijn voor een gebrekkige aansluiting tussen opleiding en beroepspraktijk. Op basis van de cijfers in tabel 5.3 zou derhalve de conclusie kunnen worden getrokken dat er weinig verschillen zijn tussen de beroepsopleidende leerweg, de beroepsbegeleidende leerweg ten aanzien van de voorbereiding op de beroepspraktijk.

Tabel 5.3

Deelname aan aanvullende scholing naar hoogst voltooide opleiding in procenten

\begin{tabular}{lrrrr}
\hline & BOL & BBL & VBO-MAVO & Totaal \\
\hline Meerdere aanvullende opleidingen & 5,2 & 12,0 & 5,8 & 6,3 \\
Eén aanvullende opleiding & 16,4 & 15,8 & 17,9 & 16,7 \\
Geen aanvullende scholing & 78,4 & 72,1 & 76,3 & 76,9 \\
\hline
\end{tabular}

Echter, aan het volgen van een opleiding of cursus kunnen verschillende motieven ten grondslag liggen. Het volgen van aanvullende scholing kan betekenen dat de in de initiële opleiding verworven kennis en vaardigheden niet volledig aansluiten op de 
in de baan vereiste kennis en vaardigheden. Het kan echter ook een indicatie van de kansen en mogelijkheden zowel op als buiten de arbeidsmarkt bieden. Aanvullende scholing kan immers ook een opstap zijn naar een (betere) baan bij dezelfde of een andere werkgever. Ten slotte kan aanvullende scholing een middel zijn om de loopbaan een geheel andere wending te geven. De scholing heeft in dit geval meer het karakter van omscholing. Om een goed zicht te kunnen krijgen op het karakter van de scholing wordt in tabel 5.4 gekeken naar de belangrijkste redenen voor het verwerven van additionele kennis en vaardigheden.

Tabel 5.4

Belangrijkste reden voor het volgen van aanvullende scholing naar hoogst voltooide opleiding in procenten

\begin{tabular}{lrrrr}
\hline & BOL & BBL & VBO-MAVO & Totaal \\
\hline Bijscholing voor de functie & & & & \\
waar ik toen werkzaam was & 34,1 & 34,0 & 21,5 & 30,3 \\
Omscholing voor andere functie & 4,3 & 2,0 & 14,0 & 6,8 \\
Om een hogere functie & & & 15,1 & 10,7 \\
te kunnen vervullen & 9,1 & 8,0 & 11,8 & 14,0 \\
Om meer kansen te hebben & 15,9 & 12,0 & 35,5 & 35,5 \\
op de arbeidsmarkt & 34,1 & 40,0 & 2,2 & 2,6 \\
Om mezelf verder te ontplooien & 2,4 & 4,0 & & \\
Overig & & & & \\
\hline
\end{tabular}

In de tabel zijn de drie hierboven genoemde redenen voor scholing duidelijk terug te vinden. Aan meer dan de helft van de scholingstrajecten of cursussen ligt het vergroten van de ontplooiingsmogelijkheden ten grondslag. Ongeveer $35 \%$ noemt immers ontplooiing direct als belangrijkste reden, terwijl respectievelijk ruim $10 \%$ en $14 \%$ aangeeft de kansen op een hogere functie of de arbeidsmarkt te willen vergroten. Omscholing blijkt over het algemeen nauwelijks een thema te zijn. Slechts ongeveer $7 \%$ van de scholingstrajecten hebben het karakter van omscholing voor een andere functie. Alleen bij respondenten zonder startkwalificatie is er wat vaker sprake van omscholing. Blijkbaar blijkt het niet hebben van een startkwalificatie iets vaker te leiden tot een kwetsbare positie op de arbeidsmarkt die aanleiding kan geven tot omscholing.

Het interessantst in het kader van dit onderzoek is de vraag in hoeverre scholingstrajecten of cursussen het karakter hebben van bijscholing in het kader van de huidige functie. Dit blijkt in ongeveer $30 \%$ van de gevallen zo te zijn. Tussen de BOL'ers en BBL'ers zijn er opmerkelijk weinig verschillen. Dit zou kunnen betekenen dat de beroepsopleidende en de beroepsbegeleidende leerweg een ongeveer even goede voorbereiding op de beroepspraktijk bieden Respondenten zonder startkwalificatie geven aan veel minder vaak bijscholing te volgen. Hierbij dient echter wel te worden benadrukt dat zij over het algemeen op een lager niveau werkzaam zijn.

\subsection{Beloning}

De beloning geeft op twee manieren een indicatie van succes op de arbeidsmarkt. Op de eerste plaats is het een directe indicator. Hoe hoger de beloning, hoe 
succesvoller iemand is op de arbeidsmarkt. De beloning kan ook op indirecte wijze een indicator zijn voor de arbeidsmarktpositie. Hoe beter de aansluiting tussen opleiding en beroepspraktijk, met andere woorden: hoe beter de match, hoe beter iemand functioneert in de baan. Verwacht mag worden dat deze hogere productiviteit beloond wordt door de werkgever. Kortom: hoe beter de match, hoe hoger het loon. Tabel 5.5 geeft de gemiddelde beloning voor de drie groepen weer. De tabel laat zien dat BBL'ers meer verdienen dan zowel BOL'ers als respondenten zonder startkwalificatie.

Tabel 5.5

Bruto uurloon naar hoogst voltooide opleiding in guldens

\begin{tabular}{lc}
\hline & Bruto uurloon \\
\hline BOL & 13,06 \\
BBL & 13,51 \\
VBO-MAVO & 13,00 \\
Totaal & 13,07 \\
\hline
\end{tabular}

De vraag is nu: worden BBL'ers op grond van hun opleidingsachtergrond beter beloond? Of zijn er andere factoren in het spel? Om na te gaan welke arbeidskrachten in welke banen het best worden beloond, is een loonvergelijking geschat waarin de logaritme van het bruto uurloon wordt verklaard in een lineaire vergelijking op basis van een aantal baan- en persoonskenmerken, waaronder de hoogst voltooide opleiding. De resultaten van deze schatting worden gepresenteerd in tabel 5.6.

Het meest in het oog springende resultaat in tabel 5.6 is het feit dat BBL'ers inderdaad significant meer verdienen dan zowel BOL'ers als respondenten zonder startkwalificatie, ook wanneer voor een aantal persoons- en baankenmerken gecorrigeerd wordt. Mogelijk wordt ook de werkervaring opgedaan tijdens het leertraject door de werkgever beloond. De beloning van BOL'ers en respondenten zonder startkwalificatie ligt op een vergelijkbaar niveau. Enerzijds hebben BOL'ers een hoger kwalificatieniveau; anderzijds hebben zij veel minder werkervaring dan respondenten zonder startkwalificatie. Blijkbaar houden deze twee effecten elkaar op dit moment van de loopbaan min of meer in evenwicht. Op de tweede plaats blijkt een baan op niveau, zoals verwacht, significant beter te belonen. Met andere woorden: hoe beter de match tussen opleiding en beroep, hoe hoger de beloning. Verder blijkt onder meer uit de tabel dat de beloning in grote bedrijven significant hoger is. Dit zou te maken kunnen hebben met het de grotere scholings- en doorgroeimogelijkheden in de grotere bedrijven. Verder blijkt een opleiding in de sector gedrag en maatschappij opvallend hoog beloond te worden in vergelijking met bijvoorbeeld een economische opleiding. 
Tabel 5.6

Effect van een aantal baan- en persoonskenmerken op de logaritme van het bruto uurloon

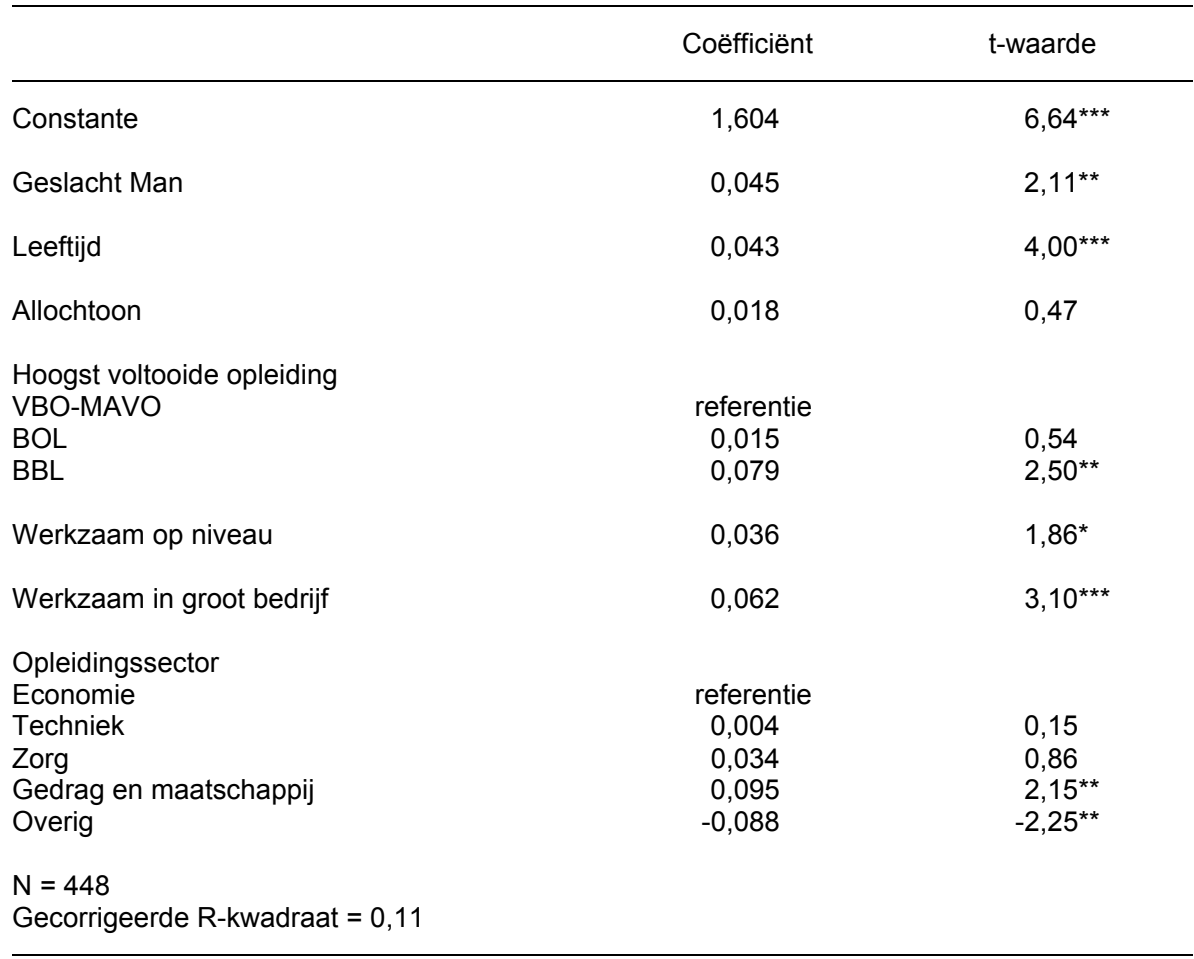

$\star * *$ = significant op $1 \%$-niveau

** $=$ significant op $5 \%$-niveau

* $\quad$ = significant op $10 \%$-niveau

\subsection{Conclusie}

In dit hoofdstuk stond de huidige arbeidsmarktpositie, dat wil zeggen de arbeidsmarktpositie zo'n vijf jaar na het verlaten van de VBO- of MAVO-opleiding centraal. Lang niet alle respondenten zijn overigens tot de arbeidsmarkt toegetreden. Een opvallend groot percentage beschouwt zichzelf nog steeds als student.

De arbeidsmarktpositie kan over het algemeen als goed bestempeld worden. De werkloosheid is laag, velen hebben een vaste baan gevonden en de aansluiting tussen opleiding en beroepspraktijk is qua richting over het algemeen goed. BBL'ers verdienen beduidend meer dan zowel BOL'ers als respondenten zonder startkwalificatie, ook wanneer voor een aantal persoons- en baankenmerken gecorrigeerd wordt. Mogelijk wordt ook de werkervaring opgedaan tijdens het leertraject door de werkgever beloond. De beloning van BOL'ers en respondenten zonder startkwalificatie ligt op een vergelijkbaar niveau. Enerzijds hebben BOL'ers een hoger kwalificatieniveau; anderzijds hebben zij veel minder werkervaring dan respondenten zonder startkwalificatie. Blijkbaar houden deze twee effecten elkaar op dit moment van de loopbaan min of meer in evenwicht. 
De deelname aan aanvullende scholing is relatief beperkt. Meer dan driekwart van de respondenten heeft na het verlaten van de opleiding geen aanvullende scholing meer gevolgd. Aan meer dan de helft van de scholingstrajecten of cursussen ligt het vergroten van de ontplooiingsmogelijkheden ten grondslag. Omscholing blijkt over het algemeen nauwelijks een thema te zijn. Alleen bij respondenten zonder startkwalificatie is er wat vaker sprake van omscholing. Blijkbaar blijkt het niet hebben van een startkwalificatie iets vaker te leiden tot een kwetsbare positie op de arbeidsmarkt die aanleiding kan geven tot omscholing. Ongeveer $30 \%$ van de scholingstrajecten heeft het karakter van bijscholing in het kader van de huidige functie. Tussen de BOL'ers en BBL'ers zijn er opmerkelijk weinig verschillen. Dit zou kunnen betekenen dat de beroepsopleidende en de beroepsbegeleidende leerweg een ongeveer even goede voorbereiding op de beroepspraktijk bieden. 



\section{Evaluatie en toekomstverwachtingen}

\subsection{Inleiding}

In dit hoofdstuk wordt zowel terug- als vooruitgeblikt. Op de eerste plaats wordt de studiekeuze van de onderzochte jongeren tegen het licht gehouden. Daaruit wordt duidelijk of ze opnieuw dezelfde opleiding zouden kiezen, of dat ze liever een andere opleiding hadden gevolgd. Ook wordt duidelijk of jongeren die direct zijn gaan werken achteraf liever wel een opleiding hadden gevolgd. Met deze eigen evaluatie van de destijds gemaakte keuze kan inzicht worden verkregen in de mate waarin jongeren via het onderwijs een voor hen geschikte opleiding gaan volgen. Dit zegt tevens iets over de macrodoelmatigheid van het onderwijs; namelijk of de onderwijsdoelen op een efficiënte manier worden bereikt. Als iemand aanvankelijk een verkeerde studiekeuze maakt, is dit minder efficiënt dan wanneer iemand direct de juiste opleiding kiest.

Er wordt tevens bekeken in hoeverre de gevolgde opleiding invloed heeft op de mate waarin de jongeren competenties hebben verworven. Van deze competenties wordt vervolgens beschreven waar de jongeren ze voornamelijk hebben opgedaan: de vooropleiding (MAVO/VBO), de vervolgopleiding (BOL/BBL), het werk, of elders. Op die manier kan inzicht worden verkregen welke bijdrage de opleiding levert bij het verwerven van competenties. Tot slot wordt er ingegaan op de toekomstverwachtingen van de onderzochte jongeren. Aan hen is de vraag voorgelegd wat hun belangrijkste bezigheid over vijf jaar zal zijn. Er wordt tevens gekeken of men bereid is om nog aan een langdurige opleiding te beginnen. Dit is met name bij degenen die direct zijn gaan werken interessant om te weten, omdat het aangeeft of men zich alsnog zou willen laten scholen, hetgeen zou kunnen resulteren in het behalen van een startkwalificatie.

\subsection{Een evaluatie van de studie- en beroepskeuze}

In tabel 6.1 tot en met tabel 6.3 staat beschreven hoe de onderzochte jongeren denken over de studiekeuze die zij gemaakt hebben ${ }^{20}$, dan wel de keuze om direct te gaan werken. Van degenen die een BOL-diploma hebben gehaald geeft ruim driekwart aan dat zij dezelfde opleiding opnieuw zouden volgen. Bijna eenvijfde (17\%) geeft aan liever een andere BOL-opleiding te hebben gevolgd. Slechts één procent geeft aan liever een BBL-opleiding te hebben gevolgd of direct te zijn gaan werken. Hieruit kan worden geconcludeerd dat respondenten met een BOL-diploma over het algemeen tevreden zijn met de door hun gemaakte studiekeuze. Als men al liever een andere opleiding had willen doen, dan is dat een andere BOL-opleiding en niet een BBL-opleiding.

20. Indien iemand meerdere opleidingen heeft gevolgd, is de laatste opleiding genomen die men gediplomeerd heeft verlaten. 
Tabel 6.1

Evaluatie van de BOL-opleiding

\begin{tabular}{lr}
\hline in \% & BOL \\
\hline Dezelfde opleiding & 78 \\
Andere BOL-opleiding & 17 \\
Een BBL-opleiding & 1 \\
Direct gaan werken & 1 \\
Anders & 3 \\
Totaal & 100 \\
& $(\mathrm{~N}=770)$ \\
\hline
\end{tabular}

Eveneens driekwart van de BBL-gediplomeerden is tevreden met de gemaakte studiekeuze; zij zouden opnieuw dezelfde opleiding kiezen. Van de overigen geeft $13 \%$ aan liever een andere BBL-opleiding te hebben gevolgd, terwijl $6 \%$ aangeeft liever een BOL-opleiding te hebben gevolgd. Het komt derhalve iets vaker voor dat BBL'ers liever een BOL-opleiding hadden willen volgen dan dat BOL'ers liever een BBL-opleiding hadden willen volgen. Opvallend is dat vrijwel niemand met een BBLdiploma achteraf gezien liever direct had willen werken. BBL'ers zijn veelal praktisch ingesteld en kiezen daarom vaak voor een combinatie van werken en leren. De keuze voor het BBL-onderwijs lijkt derhalve weloverwogen; ondanks deze praktische instelling wordt er bewust voor een leertraject gekozen.

Tabel 6.2

Evaluatie van de BBL-opleiding

\begin{tabular}{lr}
\hline in $\%$ & BBL \\
\hline Dezelfde opleiding & 75 \\
Andere BBL-opleiding & 13 \\
Een BOL-opleiding & 6 \\
Direct gaan werken & 0 \\
Anders & 6 \\
Totaal & 100 \\
& $(\mathrm{~N}=200)$ \\
\hline
\end{tabular}

Van degenen die direct na het schoolverlaten zijn gaan werken ${ }^{21}$, zegt de ruime meerderheid (85\%) dat zij dit opnieuw zouden doen. Wel geeft $15 \%$ hiervan aan liever met ander werk te zijn begonnen. Slechts $9 \%$ van de respondenten geeft aan dat zij achteraf bezien liever een opleiding hadden gevolgd in plaats van direct te gaan werken. Dit is opmerkelijk, aangezien deze groep het halverwege de jaren ' 90 , toen de arbeidsmarktsituatie zeker niet rooskleurig was, moeilijk heeft gehad een plek op de arbeidsmarkt te veroveren. Hierbij is het volgen van een BOL-opleiding $(7 \%)$ veel populairder dan het volgen van een BBL-opleiding (2\%). Ook deze uitkomst is opmerkelijk, omdat men zou denken dat een BBL-opleiding met een combinatie van leren en werken meer voor de hand ligt voor iemand die graag wil werken.

21. Van de 151 respondenten die direct zijn gaan werken na het schoolverlaten hebben er 17 (11\%) uiteindelijk nog een diploma behaald. Deze zijn hier niet meegerekend: tabel 6.3 heeft betrekking op degenen die verder geen startkwalificatie hebben behaald. 
Tabel 6.3

Evaluatie van direct gaan werken

\begin{tabular}{lc}
\hline in $\%$ & Direct werkenden \\
\hline Hetzelfde werk & 70 \\
Ander werk & 15 \\
Een BOL-opleiding & 7 \\
Een BBL-opleiding & 2 \\
Anders & 6 \\
Totaal & 100 \\
& $(\mathrm{~N}=134)$ \\
\hline
\end{tabular}

Samenvattend is de meerderheid van de respondenten tevreden met de gemaakte keuze. Als men al liever een (andere) opleiding had willen volgen dan is dit vaker een BOL-opleiding dan een BBL-opleiding. Hierbij dient wel opgemerkt te worden dat deze cijfers betrekking hebben op het huidige kwalificatieniveau. Het gaat derhalve niet over de eventuele spijt over de initiële keuze. In hoofdstuk 4 is aandacht geschonken aan het switchen tussen opleidingen en/of de arbeidsmarkt. Juist onder deze switchers zullen een groot aantal spijtoptanten te vinden zijn. Hoofdstuk 4 liet zien het aantal switchers over het algemeen gering is. Het feit dat de tabellen 6.1 tot en met 6.3 laat zien dat ongeveer driekwart uiteindelijk toch tevreden is en een nog groter deel niet voor een (andere) leerweg of voor de arbeidsmarkt zou hebben gekozen, geeft aan dat het scala aan mogelijkheden dat VBO- en MAVOschoolverlaters geboden wordt, hen in staat stelt uiteindelijk een bevredigend traject te doorlopen.

\subsection{Evaluatie van competenties en toekomstverwachtingen}

Er is aan de respondenten gevraagd een eigen inschatting te maken van hun kennis en vaardigheden op diverse gebieden door het geven van een rapportcijfer van 1 (erg slecht) tot en met 10 (uitstekend). Hiermee kan inzicht worden verkregen in het competentieniveau van de respondenten en in eventuele verschillen tussen BOL- en BBL-gediplomeerden en jongeren zonder een startkwalificatie. In tabel 6.4 worden de resultaten gepresenteerd. Een vergelijking tussen de drie groepen is vooral interessant ten aanzien van wat minder aan de vakinhoud gerelateerde competenties, zoals de steeds belangrijker wordende houdingsaspecten. Aangezien ten aanzien van de vakinhoudelijke aspecten van het werk het referentiekader verschilt, is een vergelijking ten aanzien van deze competenties een stuk moeilijker. De tabel laat zien dat over het algemeen de verschillen tussen de drie groepen opvallend gering $z_{i j n}{ }^{22}$. Het is een gegeven dat de respondenten consequent min of meer hetzelfde scoren op de diverse competenties. Computerkennis en buitenlandse talen worden bijvoorbeeld door alle respondenten minder hoog ingeschat dan zelfstandigheid en werken in teamverband.

22. Dit zou kunnen liggen aan het feit dat het hier een zelfinschatting door de respondenten betreft, hetgeen wellicht in dit geval niet onderscheidend genoeg werkt. Een test van de diverse competenties zou waarschijnlijk meer accurate gegevens opleveren, maar is praktisch moeilijk realiseerbaar. 
In het licht van de over het algemeen geringe verschillen, is het effect van de gevolgde opleiding op computerkennis opvallend. Hoewel de scores laag zijn, geven BOL'ers aan over meer computerkennis te beschikken $(6,3)$ dan BBL'ers $(5,4)$. BOL'ers geven iets hogere rapportcijfers voor buitenlandse talen en schriftelijke presentatie dan BBL'ers en direct werkenden.

Tabel 6.4

Oordeel over competentieniveau (standaarddeviatie tussen haakjes)

\begin{tabular}{lccc}
\hline & BOL & BBL & Overig $^{23}$ \\
\hline Kennis van eigen vakgebied & 7,3 & 7,6 & 7,4 \\
& $(1,13)$ & $(0,72)$ & $(1,17)$ \\
Praktische vaardigheden in eigen vakgebied & 7,4 & 7,7 & 7,5 \\
& $(1,20)$ & $(0,80)$ & $(1,13)$ \\
Computerkennis & 6,3 & 5,4 & 5,8 \\
& $(1,97)$ & $(2,61)$ & $(2,35)$ \\
Buitenlandse talen & 6,2 & 5,9 & 6,0 \\
& $(1,61)$ & $(1,46)$ & $(1,86)$ \\
Plannen/organiseren & 7,0 & 6,9 & 7,0 \\
& $(1,25)$ & $(1,46)$ & $(1,30)$ \\
Mondelinge presentatie & 7,1 & 7,0 & 6,9 \\
& $(1,13)$ & $(1,40)$ & $(1,60)$ \\
Schriftelijke presentatie & 7,0 & 6,7 & 6,7 \\
& $(1,16)$ & $(1,48)$ & $(1,55)$ \\
Probleemoplossend vermogen & 7,4 & 7,4 & 7,4 \\
Werken in teamverband & $(0,98)$ & $(1,20)$ & $(1,11)$ \\
Zelfstandigheid & 7,8 & 7,8 & 7,9 \\
& $(1,02)$ & $(1,25)$ & $(1,09)$ \\
Nauwkeurigheid & 7,8 & 7,9 & 8,0 \\
& $(0,92)$ & $(0,74)$ & $(0,96)$ \\
& 7,5 & 7,7 & 7,6 \\
& $(0,96)$ & $(0,88)$ & $(1,13)$ \\
\hline
\end{tabular}

Er is eveneens aan de respondenten gevraagd waar men hoofdzakelijk deze competenties heeft verworven; in de vooropleiding, de vervolgopleiding, of op het werk. De meeste competenties heeft men voornamelijk op het werk of in de vervolgopleiding verworven, met uitzondering van buitenlandse talen. Deze competentie is voornamelijk in de vooropleiding verworven. Andere competenties die eveneens in de vooropleiding worden verworven zijn schriftelijke en mondelinge presentatie en computerkennis. BOL'ers geven veel vaker dan BBL'ers aan dat zij een bepaalde competentie hoofdzakelijk in de vervolgopleiding hebben verworven. BBL'ers zeggen veel vaker op het werk competenties te hebben opgedaan. Degenen die direct na het schoolverlaten zijn gaan werken, geven vaker dan BOL'ers en BBL'ers aan hun competenties elders te hebben verworven (dus niet in een opleiding of op het werk). Zij geven ook vaker aan hun competenties voornamelijk in de vooropleiding te hebben verworven. Deze bevindingen laten opnieuw zien dat de verschillende leerwegen een duidelijke te onderscheiden functie vervullen en een

23. In deze categorie vallen jongeren die direct na het schoolverlaten zijn gaan werken of iets anders zijn gaan doen (bijvoorbeeld: onbetaald werk, zorgtaken/huishouden, werkloos). Zij zijn verder niet in het bezit van een startkwalificatie.

40 
groot aantal VBO- en MAVO-schoolverlaters op verschillende manieren in staat stellen een startkwalificatie te behalen.

Om inzicht te krijgen in de toekomstverwachtingen van de jongeren is er gevraagd wat zij denken dat over vijf jaar hun belangrijkste bezigheid is en of ze in de komende vijf jaar nog aan een opleiding langer dan één jaar zouden willen beginnen. Dit laatste meet de opleidingsbereidheid en is met name van belang voor degenen zonder startkwalificatie. Er is vrijwel geen verschil in opleidingsbereidheid tussen degenen die een BOL- of BBL-opleiding hebben afgerond (48\%) en degenen die direct zijn gaan werken (45\%). Hieruit kan worden geconcludeerd dat bijna de helft van de ondervraagden in de komende jaren bereid is langdurige scholing te volgen.

Niet alleen de opleidingsbereidheid is onderzocht. Ook is gevraagd naar de verwachtingen over de maatschappelijke positie. Tabel 6.5 laat zien wat naar verwachting de belangrijkste bezigheid over vijf jaar zal zijn. Verreweg de meerderheid van de BOL'ers en BBL'ers (90\%) geeft aan dat dit betaald werk zal zijn. Onder degenen die geen startkwalificatie hebben behaald (in de categorie 'overig') is dit percentage lager, namelijk $81 \%$. Van deze respondenten geeft $13 \%$ aan zich voornamelijk met zorgtaken/huishouden bezig te zullen houden. Niemand verwacht over vijf jaar werkloos te zijn. Slechts enkelen verwachten dan nog bezig te zijn met een BOL-, BBL-, of HBO-opleiding.

Tabel 6.5

Belangrijkste bezigheid over vijf jaar

\begin{tabular}{lrrr}
\hline in \% & BOL & BBL & Overig $^{24}$ \\
\hline Onbetaald werk & 1 & 0 & 1 \\
BOL-opleiding & 1 & 1 & 2 \\
BBL-opleiding & 1 & 1 & 1 \\
Betaald werk & 90 & 89 & 81 \\
Werkloos/werkzoekend & 0 & 0 & 0 \\
Zorgtaken/huishouden & 5 & 7 & 13 \\
HBO-vervolgopleiding & 1 & 0 & 0 \\
Anders & 1 & 3 & 3 \\
Totaal & 100 & 100 & 100 \\
& $(\mathrm{~N}=694)$ & $(\mathrm{N}=161)$ & $(\mathrm{N}=360)$ \\
\hline
\end{tabular}

\subsection{Conclusie}

De meerderheid van de onderzochte jongeren is tevreden met de gemaakte studieen beroepskeuze direct na het schoolverlaten en zou weer opnieuw dezelfde opleiding of hetzelfde werk kiezen. Degenen die dit niet zouden doen geven vaker aan liever een BOL-opleiding te hebben gevolgd dan een BBL-opleiding. Relatief weinig jongeren die direct zijn gaan werken geven aan achteraf liever een opleiding te hebben gevolgd. Hieruit kan geconcludeerd worden dat het scala aan mogelijkheden dat VBO- en MAVO-schoolverlaters geboden wordt, hen in staat stelt uiteindelijk een bevredigend traject te doorlopen.

24. Deze categorie 'overig' is op dezelfde respondenten gebaseerd als die in tabel 6.4. 
Een vergelijking tussen BOL'ers, BBL'ers en respondenten zonder statkwalificatie ten aanzien van het competentieniveau is moeilijk. Het referentiekader verschilt immers tussen de drie groepen. Wat wel duidelijk is geworden is dat er belangrijke verschillen zijn ten aanzien van de wijze waarop men de diverse competenties hoofdzakelijk zegt te hebben verworven. BOL-gediplomeerden noemen vaker de vervolgopleiding als belangrijkste bron voor het verwerven van competenties, terwijl BBL-gediplomeerden vaker het werk noemen. Direct werkenden geven vaker aan hun competenties in de vooropleiding of ergens anders te hebben verworven. In het algemeen worden de meeste competenties in de vervolgopleiding of op het werk verworven. Deze bevindingen laten opnieuw zien dat de verschillende leerwegen een duidelijke te onderscheiden functie vervullen en een groot aantal VBO- en MAVOschoolverlaters op verschillende manieren in staat stellen een startkwalificatie te behalen.

Bijna de helft van de ondervraagden is bereid om in de komende jaren langdurige scholing te volgen. Er is geen onderscheid in opleidingsbereidheid tussen BOL- of BBL-gediplomeerden en direct werkenden. Veruit de meerderheid van de respondenten denkt dat de belangrijkste bezigheid over vijf jaar betaald werk zal zijn. 


\section{Conclusie}

Schoolverlaters van het lager secundair onderwijs staan voor een belangrijke keuze. $\mathrm{Na}$ het verlaten van de opleiding staan deze schoolverlaters, naast doorstroom in het algemeen voortgezet onderwijs, twee leerwegen open in het beroepsonderwijs: de beroepsopleidende en de beroepsbegeleidende leerweg. Daarnaast is het mogelijk dat de schoolverlaters de arbeidsmarkt betreden zonder verdere vorm van kwalificering. Uit maatschappelijk oogpunt wordt deze derde weg in het algemeen als ongewenst beschouwd en het overheidsbeleid is er dan ook in het bijzonder op gericht om deze jongeren alsnog een zogeheten startkwalificatie te laten behalen.

In dit rapport is getracht inzicht te verwerven in de lange termijn effecten (dat wil zeggen zo'n vijf jaar na het verlaten van een VBO- of MAVO-opleiding) van deze keuzes. Het rapport laat zien dat investeren in het verwerven van een startkwalificatie loont. De arbeidsmarktpositie van zowel BOL'ers als BBL'ers kan als goed bestempeld worden. De opleiding heeft een positief effect op de beloning. BBL'ers verdienen beduidend meer dan arbeidskrachten zonder startkwalificatie. De beloning van BOL'ers is vergelijkbaar met het loon dat arbeidskrachten zonder startkwalificatie ontvangen. Enerzijds hebben BOL'ers een hoger kwalificatieniveau; anderzijds hebben zij veel minder werkervaring dan respondenten zonder startkwalificatie. Blijkbaar houden deze twee effecten elkaar op dit moment van de loopbaan min of meer in evenwicht. Uit eerder onderzoek is echter gebleken dat BOL'ers die achterstand op BBL'ers snel weten in te halen (Van der Velden en Lodder, 1995).

Het feit dat een investering in een BOL- of BBL-opleiding loont betekent niet dat er zonder startkwalificatie geen volwaardige plek op de arbeidsmarkt te verwerven is. Ook schoolverlaters van het VBO en de MAVO die gekozen hebben voor de arbeidsmarkt blijken inmiddels een goede arbeidsmarktpositie te hebben verworven. De werkloosheid is laag, een groot deel heeft een vaste aanstelling en er is sprake van een goede aansluiting tussen opleiding en beroepspraktijk. Dit beeld is opmerkelijk, gezien de ongunstige arbeidsmarktsituatie in het midden van de jaren '90. Blijkbaar zijn ook degenen zonder startkwalificatie in staat gebleken om zich staande te houden op de arbeidsmarkt in een periode met economische tegenwind.

Ook blijken de respondenten zonder startkwalificatie tevreden te zijn met hun situatie. Dit blijkt uit een aantal factoren. Op de eerste plaats blijkt hun keuze voor de arbeidsmarkt weloverwogen te zijn. Men heeft bijvoorbeeld het gevoel een goede studie- en beroepskeuzebegeleiding te hebben gehad. Bovendien blijkt slechts een kleine groep achteraf spijt te hebben van de keuze. Op de tweede plaats behaalt slechts $11 \%$ van de VBO'ers en MAVO-leerlingen die aanvankelijk voor de arbeidsmarkt kozen achteraf alsnog een diploma. Meestal is dit een BBL-diploma, hetgeen erop wijst dat een BBL-opleiding blijkbaar laagdrempeliger is voor scholieren die alsnog een startkwalificatie willen behalen dan een voltijdse BOL-opleiding. De beroepsbegeleidende leerweg vervult daarmee een belangrijke functie om mensen die aanvankelijk voor de arbeidsmarkt kozen de kans de bieden alsnog een startkwalificatie te behalen. Op de derde plaats is de bereidheid onder arbeidskrachten zonder startkwalificatie om langdurige scholing te volgen vergelijkbaar met 
middelbaar opgeleiden. Deze drie factoren laten zien dat schoolverlaters van het VBO en de MAVO die vervolgens voor de arbeidsmarkt kiezen zeker perspectief hebben op de arbeidsmarkt.

Ook degenen die gekozen hebben voor een BOL- of een BBL-opleiding kijken met een grote mate van tevredenheid terug. Het aantal spijtoptanten is gering. Bovendien blijken relatief weinig mensen tijdens de opleiding te switchen tussen de leerwegen. Een overstap van een BBL-opleiding naar de beroepsopleidende leerweg komt het meest voor. Het overall-rendement van het middelbaar beroepsonderwijs bedraagt ruim $75 \%$. Ruim driekwart van de BOL'ers en BBL'ers behaalt uiteindelijk een diploma. Slechts ruim $20 \%$ van degenen die aan een middelbare beroepsopleiding zijn begonnen, verlaat zonder startkwalificatie het onderwijs. Het brede scala aan mogelijkheden dat de VBO'er en de MAVO-leerling ter beschikking staat leidt er blijkbaar toe dat een groot deel van hen een vervolgtraject kan kiezen dat bij hen past. Uiteindelijk weten BOL'ers en BBL'ers, ondanks de verschillende leerwegen waarin de accenten in de wijze van het verwerven van competenties verschillen, een vergelijkbare positie op de arbeidsmarkt te verwerven. Het competentieniveau lijkt elkaar niet veel te ontlopen, de behoefte aan bijscholing is vergelijkbaar en ook de arbeidsmarktpositie is voor beide leerwegen als goed te bestempelen. Al met al lijken de beroepsopleidende en de beroepsbegeleidende leerweg een ongeveer even goede voorbereiding op de beroepspraktijk te bieden.

Dit rapport doet verslag van een onderzoek dat primair tot doel had meer inzicht te verkrijgen in de lange termijn effecten van keuzes die schoolverlaters van het VBO en de MAVO maken. In deze conclusie zijn de belangrijkste bevindingen van dit onderzoek kort samengevat. Het is belangrijk te benadrukken dat de in dit rapport gepresenteerde resultaten inzicht verschaffen in het extern rendement van de initiële opleidingskeuze en veel minder in het extern rendement van de opleidingen. Voor het adequaat meten van het extern rendement van opleidingen is een meting zo'n vijf jaar na het verlaten van de VBO- of MAVO-opleiding eigenlijk nog te vroeg. Het rapport heeft laten zien dat een groot deel van de respondenten de opleiding nog niet heeft afgerond. Bovendien bevinden de verschillende groepen zich in een verschillende fase van de loopbaan. Degenen die na het afronden van de VBO- of MAVO-opleiding meteen zijn gaan werken, hebben inmiddels zo'n vijf jaar werkervaring. BBL'ers hebben weliswaar veel later een positie op de arbeidsmarkt verworven, maar hebben tijdens de opleiding al behoorlijk wat praktijkervaring opgedaan. BOL'ers zijn het meest onervaren. Zij hebben hun opleiding over het algemeen pas recent afgerond en hebben juist hun eerste stappen op de arbeidsmarkt gezet. Deze verschillen leiden ertoe dat een goede vergelijking van het externe rendement van de BOL, de BBL en de keuze voor direct werken zo'n vijf jaar na het verlaten van het VBO of de MAVO nog niet goed mogelijk is.

Dit impliceert dat, een vervolgmeting, bijvoorbeeld acht of tien jaar na het verlaten van de VBO- of MAVO-opleiding, zinvol kunnen zijn. Deze vervolgmeting zou meer inzicht kunnen verschaffen in het extern (arbeidsmarkt)rendement van de verschillende leerwegen in verhouding tot degenen die geen startkwalificatie hebben behaald, Maar ook het opnieuw uitvoeren van een vergelijkbaar onderzoek kan van 
grote waarde zijn. In een vervolgonderzoek zullen de gevolgen van de invoering van de WEB-structuur in volle omvang zichtbaar worden. De resultaten van het nu afgeronde onderzoek kunnen als ijkpunt gebruikt worden om deze gevolgen in kaart te brengen. Ook de implicaties van de veranderingen in het VBO, i.c. de invoering van het $\mathrm{VMBO}$, kunnen middels een nieuw onderzoek geanalyseerd worden. Zo rijst bijvoorbeeld de vraag in hoeverre het VMBO de overstap naar de beroepsopleidende leerweg vergemakkelijkt. In dit onderzoek hebben we immers gezien dat VBO'ers vooral voor de beroepsbegeleidende leerweg kiezen. Daarnaast kan de vraag gesteld worden in hoeverre schoolverlaters zonder startkwalificatie ook in de nieuwe structuur een volwaardige plek op de arbeidsmarkt kunnen verwerven. 



\section{Literatuur}

Portengen, R. \& H. Dekkers (1998), Arbeids- en onderwijsloopbanen van zeer voortijdig schoolverlaters, The J.H.G.I Giesbers Reports on Education, 6, pp. 24-42.

Researchcentrum voor Onderwijs en Arbeidsmarkt (1999), Schoolverlaters tussen Onderwijs en Arbeidsmarkt 1998, ROA-R-1999/5, Maastricht.

Researchcentrum voor Onderwijs en Arbeidsmarkt (2000), Schoolverlaters tussen Onderwijs en Arbeidsmarkt 1999, ROA-R-2000/7, Maastricht.

Researchcentrum voor Onderwijs en Arbeidsmarkt (2001), Schoolverlaters tussen Onderwijs en Arbeidsmarkt 2000, ROA-R-2001/3, Maastricht.

Thurow, L. (1975), Generating Inequality, Basic Books, New York.

Velden, R. van der \& B. Lodder (1995), Alternative routes from vocational education to the labour market, Educational Research and Evaluation, 1, blz. 109-128. 



\section{Bijlage 1: De Wet Educatie en Beroepsonderwijs (WEB)}

Sinds 1 januari 1996 is de Wet Educatie en Beroepsonderwijs (WEB) van kracht waarin een nieuwe kwalificatiestructuur voor het middelbaar beroepsonderwijs is vastgelegd. In het onderstaande schema wordt een overzicht gegeven van de relatie tussen de oude en de nieuwe kwalificatiestructuur. Belangrijkste kenmerken van de nieuwe structuur zijn de vier onderscheiden niveaus en het feit dat deze niveaus leerweg-neutraal zijn. Dat wil zeggen dat een opleiding voor alle niveaus in principe via twee leerwegen gevolgd kan worden. Allereerst is dat de beroepsopleidende leerweg $(B O L)$ die vergelijkbaar is met het oude $\mathrm{MBO}$-dagonderwijs. Daarnaast is dat de beroepsbegeleidende leerweg (BBL) waarbij minimaal $60 \%$ van de studieduur uit praktijkvorming bestaat. Deze leerweg is te vergelijken met het 'werkend leren' in het oude leerlingwezen (LLW).

Vergelijking oude en nieuwe kwalificatiestructuur volgens de WEB

\begin{tabular}{|c|c|c|c|c|}
\hline Niveau & $\begin{array}{l}\text { Nieuwe } \\
\text { opleidingsaanduiding }\end{array}$ & $\begin{array}{l}\text { Opleidingsaanduiding } \\
\text { Agrarische sector }\end{array}$ & $\begin{array}{l}\text { Oude } \\
\text { opleidingsaanduiding }\end{array}$ & Duur \\
\hline 1 & Assistentenopleiding & $\begin{array}{l}\text { Assisterend } \\
\text { beroepsbeoefenaar }\end{array}$ & - & $\begin{array}{l}0,5-1 \\
\text { jaar }\end{array}$ \\
\hline 2 & Basisberoepsopleiding & $\begin{array}{l}\text { Beginnend } \\
\text { beroepsbeoefenaar }\end{array}$ & $\begin{array}{l}\text { MBO-kort } \\
\text { LLW -primair }\end{array}$ & $\begin{array}{l}2-3 \\
\text { jaar }\end{array}$ \\
\hline 3 & Vakopleiding & $\begin{array}{l}\text { Zelfstandig } \\
\text { beroepsbeoefenaar }\end{array}$ & $\begin{array}{l}\text { MBO-tussen } \\
\text { MBO-lang } \\
\text { LLW-secundair }\end{array}$ & $\begin{array}{l}2-4 \\
\text { jaar }\end{array}$ \\
\hline 4 & Middenkaderopleiding & Kaderfunctionaris & $\begin{array}{l}\text { MBO-lang } \\
\text { LLW-tertiair }\end{array}$ & $\begin{array}{l}3-4 \\
\text { jaar }\end{array}$ \\
\hline 4 & Specialistenopleiding & $\begin{array}{l}\text { Gespecialiseerd } \\
\text { beroepsbeoefenaar }\end{array}$ & LLW-tertiair & $\begin{array}{l}1-2 \\
\text { jaar }\end{array}$ \\
\hline
\end{tabular}

Bron: LDC 



\section{Bijlage 2: Vragenlijst}

\section{Blok 1 Introductieblok}

ENQ:

Goedemiddag, u spreekt met .... van Desan Marktonderzoek. Wij doen een onderzoek naar loopbanen en zouden $u$ / <RESPONDENT> graag een aantal vragen daarover willen stellen.

Intro 1: de respondent woont nog thuis en komt zelf aan de lijn

Een aantal jaren geleden heeft u meegewerkt aan een loopbanen onderzoek. Als het goed is, heeft $u$ in <JAAR> <OPLEIDING1> afgemaakt. Ongeveer een jaar later heeft $u$ een enquête ingevuld over uw ervaringen na deze opleiding. $U$ heeft toen ook toestemming gegeven voor een vervolgonderzoek. In het kader daarvan zouden wij u een aantal vragen willen stellen. Het gesprek zal ongeveer 20 minuten duren. Heeft $u$ nu tijd hiervoor?

Intro 2: de respondent woont niet meer thuis

$<$ RESPONDENT > heeft een aantal jaren geleden al eerder meegedaan aan een onderzoek naar loopbanen en dit is een vervolg hierop. Heeft u misschien een telefoonnummer waarop ik hem/haar kan bereiken?

1 We zouden graag een overzicht willen hebben van uw bezigheden vanaf het moment van schoolverlaten in $<$ MAAND $><$ JAAR $>$ tot op heden. Het gaat hierbij om bezigheden zoals: studie, betaald of onbetaald werk, zorgtaken, maar ook werkloosheid, een hele lange vakantie of andere periodes die u van belang acht zoals zwangerschapsverlof. Het is de bedoeling dat $u$ zich dit probeert te herinneren vanaf het moment dat $u<O P L E I D I N G 1>$ heeft verlaten. Zou u kunnen vertellen wat $u$ direct na <OPLEIDING1> bent gaan doen? Hoe lang duurde dit? Wat bent u daarna gaan doen? Hoe lang duurde dit? Enz.

\section{Status $1 \mathrm{t} / \mathrm{m} 8$}

onbetaald werk

vervolgopleiding BOL/AVO/VAVO

vervolgopleiding in het leerlingwezen/BBL

betaald werk

werkloos/werkzoekend

vakantie langer dan 1 maand

zorgtaken/huishouden

anders, namelijk 


\begin{tabular}{|l|l|l|l|l|l|l|}
\hline \multicolumn{2}{|l|}{ Periode } & \multicolumn{2}{l|}{ Status } & Overig \\
\hline \multicolumn{2}{|c|}{$\begin{array}{l}\text { Van } \\
\text { (maand/jaar) }\end{array}$} & \multicolumn{2}{c|}{$\begin{array}{c}\text { Tot en met } \\
\text { (maand/jaar) }\end{array}$} & $1 \mathrm{t} / \mathrm{m} 8$ & overige activiteiten \\
\hline 1 & & $19 .$. & & $19 .$. & & $\ldots \ldots \ldots \ldots \ldots \ldots \ldots .$. \\
\hline 2 & & $19 .$. & & $19 .$. & & $\ldots \ldots \ldots \ldots \ldots \ldots \ldots .$. \\
\hline 3 & & $19 .$. & & $19 .$. & & $\ldots \ldots \ldots \ldots \ldots \ldots \ldots .$. \\
\hline 4 & & $19 .$. & & $19 .$. & & $\ldots \ldots \ldots \ldots \ldots \ldots \ldots \ldots .$. \\
\hline 5 & & $19 .$. & & $19 .$. & & $\ldots \ldots \ldots \ldots \ldots \ldots \ldots \ldots .$. \\
\hline 6 & & $19 .$. & & $19 .$. & & $\ldots \ldots \ldots \ldots \ldots \ldots \ldots \ldots .$. \\
\hline
\end{tabular}

\section{Blok 2 Vervolgopleiding BOL/AVO/VAVO}

ENQ:

$U$ heeft aangegeven dat $u$ van $<$ MAAND $><$ JAAR $>$ to $<$ MAAND $><$ JAAR $>$ een opleiding gevolgd heeft. We willen $u$ een aantal vragen over deze opleiding stellen.

$2 \quad$ Wat is de officiële naam van deze vervolgopleiding?

schooltype (bv. mbo):

opleidingsrichting (bv. elektrotechniek):.

eventueel niveau van de opleiding:.

Vragen $3 \mathrm{a}, 3 \mathrm{~b}$, en $3 \mathrm{c}$ alleen stellen aan diegenen die direct na $<$ OPLEIDING1> een opleiding in BOL/AVO/VAVO zijn gaan volgen.

3a Heeft $u$ voordat $u$ met <OPLEIDING2> begon nog andere bezigheden overwogen, zoals direct gaan werken of een opleiding in het leerlingwezen?

1 ja, direct gaan werken

2 ja, opleiding in het leerlingwezen

3 ja, anders namelijk......

4 nee

3b Wat was de belangrijkste reden om destijds aan een vervolgopleiding te beginnen? ENQ: LET OP! Hier slechts de eerstgenoemde reden aankruisen. Overige antwoorden in vraag $3 c$ aankruisen. Spontaan laten antwoorden.

1 het leek me een interessante opleiding

$2 \quad$ voor het beroep dat ik wilde had ik deze opleiding nodig

3 er was geen werk dat me interesseerde 
mijn ouders/verzorgers leek het beter dat ik door zou leren

5 doorleren leek mij verstandiger, dan kun je later meer verdienen

$6 \quad$ ik kon makkelijk leren

$7 \quad$ ik was nog (gedeeltelijk) leerplichtig

8 in het regulier voortgezet onderwijs kon ik geen examen doen

9 andere reden, namelijk:

$3 c$

Waren er verder nog belangrijke redenen om destijds aan een vervolgopleiding te beginnen? ENQ: Overige antwoorden hier invullen. Maximaal twee antwoordcategorieën aankruisen. Spontaan laten antwoorden. Doorvragen bij twijfel over welke antwoordcategorie er aangekruist moet worden.

1 het leek me een interessante opleiding

$2 \quad$ voor het beroep dat ik wilde had ik deze opleiding nodig

3 er was geen werk dat me interesseerde

4 mijn ouders/verzorgers leek het beter dat ik door zou leren

5 doorleren leek mij verstandiger, dan kun je later meer verdienen

$6 \quad$ ik kon makkelijk leren

$7 \quad$ ik was nog (gedeeltelijk) leerplichtig

8 in het regulier voortgezet onderwijs kon ik geen examen doen

9 andere reden, namelijk:

$4 \mathrm{a} t / \mathrm{m} 4 \mathrm{~d}$ vragen voor de eerste vervolgopleiding en de tweede vervolgopleiding indien men de eerste vervolgopleiding niet heeft afgemaakt.

We willen $u$ nu een paar vragen stellen over de aansluiting tussen <OPLEIDING1> en $<$ OPLEIDING VRAAG 2>.

4a Vindt $u$ dat $u$ in <OPLEIDING1> voldoende kennis hebt opgedaan om door te kunnen leren in <OPLEIDING VRAAG 2>? ENQ: Antwoorden oplezen.

ruim voldoende

voldoende

onvoldoende

ruim onvoldoende

4b Vindt $u$ dat $u$ in <OPLEIDING1> voldoende bent voorbereid op de manier van studeren in <OPLEIDING VRAAG 2>? ENQ: Bijvoorbeeld het zelfstandig kunnen leren. Antwoorden oplezen.

1 ruim voldoende

2 voldoende

3 onvoldoende

4 ruim onvoldoende

4c Wat vindt $u$ van de studie- en beroepskeuzevoorlichting die $u$ tijdens $<$ OPLEIDING1> ontvangen heeft? ENQ: Antwoorden oplezen.

1 goed

2 voldoende 


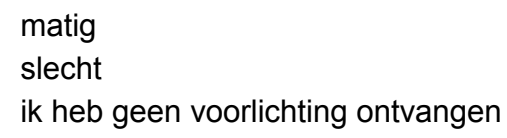

4d Wat vindt $u$ van de begeleiding van leerlingen in <OPLEIDING VRAAG 2>? ENQ: Antwoorden oplezen.

1 goed

2 voldoende

3 matig

$4 \quad$ slecht

5a Hebt u de opleiding tussentijds onderbroken? Zo ja, voor hoeveel maanden? 1 ja, voor maanden

2 nee

5b Heeft $\mathrm{u}$ op een andere manier vertraging opgelopen? (bv. een jaar blijven zitten)

1 ja, namelijk jaar

2 nee

ENQ: Check of men de opleiding nog steeds volgt door middel van een controlerende vraag aan de respondent (“U volgt deze opleiding nog/niet meer. Klopt dat?")

Als men de opleiding niet meer volgt $\rightarrow$ ga naar vraag $6 a$

Als men de opleiding nog volgt $\rightarrow$ ga naar vraag $6 \mathrm{e}$

6a Heeft u van <OPLEIDING VRAAG 2> het diploma behaald?

1 ja $\rightarrow$ ga naar $6 e$

2 nee

6b Bent $u$ binnen dezelfde opleiding nog naar een ander niveau overgestapt? ENQ: Spontaan laten antwoorden. Doorvragen indien "ja".

1 ja, naar een hoger niveau

2 ja, naar een lager niveau

3 nee

6c In welke klas bent u met <OPLEIDING VRAAG 2> gestopt?

klas:

6d

Wat was de belangrijkste reden om deze vervolgopleiding niet af te maken? ENQ: Spontaan laten antwoorden. Maximaal twee antwoordcategorieën aankruisen.

1 de opleiding viel inhoudelijk tegen/was niet zo interessant als ik dacht

$2 \quad$ ik vond de opleiding te moeilijk

3 ik wilde achteraf toch liever een andere opleiding gaan volgen

$4 \quad$ ik wilde liever gaan werken

$5 \quad$ ik had geen zin meer om te leren

$6 \quad$ ik kon ook zonder deze opleiding aan werk komen 
$7 \quad$ ik kon de opleiding niet meer bekostigen

$8 \quad \mathrm{ik}$ kreeg een baan aangeboden/ik vond werk dat me leuk leek

9 de opleiding sloot niet aan bij <OPLEIDING1>

10 anders, namelijk:

6e Zou u, acheraf bezien, opnieuw dezelfde keuze maken wat uw opleiding betreft? ENQ: Spontaan laten antwoorden.

1 ja, dezelfde opleiding

2 nee, een andere opleiding, namelijk:

3 nee, BBL-opleiding, namelijk:

$4 \quad$ nee, ik zou direct zijn gaan werken

5 nee, anders namelijk

Vraag $6 f$ alleen stellen als men de opleiding nu nog volgt.

6f In welke klas zit u nu?

klas:

Indien men aan een andere opleiding begonnen is (niet BBL!), doorloop blok 2 opnieuw voor vraag $2,5 a, 5 b$, en 6 .

\section{Blok 3 Vervolgopleiding leerlingwezen/ BBL}

ENQ:

$U$ heeft aangegeven dat $u$ van <MAAND> <JAAR> tot <MAAND> <JAAR> een opleiding in het leerlingwezen heeft gevolgd. We willen $u$ een aantal vragen over deze opleiding stellen.

$7 a$

Wat is de officiële naam van deze vervolgopleiding? Geef zowel het landelijk orgaan als de opleiding aan. ENQ: Lijst van 10 meest waarschijnlijke landelijke organen oplezen, indien men het landelijk orgaan niet meteen weet.

landelijk orgaan:

opleiding:

7b Wat was het niveau van deze opleiding? ENQ: Spontaan laten antwoorden.

1 assistentenopleiding

2 primair (basisberoepsopleiding)

3 secundair/voortgezet (vakopleiding)

4 tertiair (middenkaderopleiding)

$5 \quad$ tertiair (specialistenopleiding)

Vragen 7c, 7d, en 7e alleen stellen aan diegenen die direct na <OPLEIDING1> een opleiding in het leerlingwezen/BBL zijn gaan volgen.

7c Heeft $u$ voordat $u$ met <OPLEIDING7A> begon nog andere bezigheden overwogen, zoals direct gaan werken of een voltijd opleiding?

1 ja, direct gaan werken 
ja, een voltijd opleiding

ja, anders namelijk.....

nee

7d Wat was de belangrijkste reden om destijds een opleiding in het leerlingwezen te gaan volgen? ENQ: LET OP: Hier slechts de eerstgenoemde reden aankruisen. Overige antwoorden in vraag $7 e$ aankruisen. Spontaan laten antwoorden.

1 het leek me een interessante opleiding

$2 \quad$ voor het beroep dat ik wilde had ik deze opleiding nodig

3 er was geen voltijd opleiding die me interesseerde

4 mijn ouders/verzorgers leek het beter dat ik naar het leerlingwezen zou gaan

5 met een opleiding in het leerlingwezen kun je later meer verdienen dan wanneer je geen opleiding meer volgt

6 ik wist niet zeker of ik een diploma van een voltijd opleiding zou kunnen halen

$7 \quad$ ik was nog gedeeltelijk leerplichtig en moest daarom een opleiding volgen

8 mijn werkgever wilde dat ik deze opleiding ging volgen

$9 \quad \mathrm{ik}$ vond de combinatie van leren en werken aantrekkelijk

10 ik wilde eigenlijk gaan werken, maar ik kon geen baan vinden

11 andere reden, namelijk:

7e Waren er verder nog belangrijke redenen om destijds een opleiding in het leerlingwezen te gaan volgen? ENQ: Overige antwoorden hier invullen. Maximaal twee antwoordcategorieën aankruisen. Spontaan laten antwoorden. Doorvragen bij twijfel over welke antwoordcategorie er aangekruist moet worden.

1 het leek me een interessante opleiding

$2 \quad$ voor het beroep dat ik wilde had ik deze opleiding nodig

3 er was geen voltijd opleiding die me interesseerde

4 mijn ouders/verzorgers leek het beter dat ik naar het leerlingwezen zou gaan

5 met een opleiding in het leerlingwezen kun je later meer verdienen dan wanneer je geen opleiding meer volgt

$6 \quad \mathrm{ik}$ wist niet zeker of ik een diploma van een voltijd opleiding zou kunnen halen

$7 \quad$ ik was nog gedeeltelijk leerplichtig en moest daarom een opleiding volgen

8 mijn werkgever wilde dat ik deze opleiding ging volgen

$9 \quad \mathrm{ik}$ vond de combinatie van leren en werken aantrekkelijk

$10 \quad i k$ wilde eigenlijk gaan werken, maar ik kon geen baan vinden

11 andere reden, namelijk:

$7 f \mathrm{t} / \mathrm{m}$ 7i alleen vragen voor de eerste vervolgopleiding en de tweede vervolgopleiding indien men de eerste vervolgopleiding niet heeft afgemaakt. 
We willen $u$ nu een paar vragen stellen over de aansluiting tussen <OPLEIDING1> en $<$ OPLEIDING VRAAG 7A>.

7f Vindt $u$ dat $u$ in <OPLEIDING1> voldoende kennis hebt opgedaan om door te kunnen leren in <OPLEIDING VRAAG 7A>? ENQ: Antwoorden oplezen.

1 ruim voldoende

2 voldoende

3 onvoldoende

4 ruim onvoldoende

7g Vindt $u$ dat $u$ in <OPLEIDING1> voldoende bent voorbereid op de manier van studeren in <OPLEIDING VRAAG 7A>? ENQ: Bijvoorbeeld het zelfstandig kunnen leren. Antwoorden oplezen.

1 ruim voldoende

2 voldoende

3 onvoldoende

4 ruim onvoldoende

7h Wat vindt $\mathrm{u}$ van de studie- en beroepskeuzevoorlichting die $\mathrm{u}$ tijdens <OPLEIDING1> ontvangen heeft? ENQ: Antwoorden oplezen.

goed

voldoende

matig

slecht

ik heb geen voorlichting ontvangen

7i Wat vindt $u$ van de begeleiding van leerlingen in <OPLEIDING VRAAG 7A> door de school? ENQ: Antwoorden oplezen.

goed

voldoende

matig

slecht

$8 \quad$ Verrichtte $\mathrm{u}$ in het kader van uw opleiding ook betaald of onbetaald werk? Zo ja, wat voor type overeenkomst had u? ENQ: Spontaan laten antwoorden.

1 ja, arbeidsovereenkomst en een leerovereenkomst

2 ja, alleen leerovereenkomst met vergoeding

3 ja, alleen leerovereenkomst zonder vergoeding

4 nee, volgde alleen schoolgedeelte $\rightarrow$ ga naar vraag 13

$9 \quad$ Heeft u gedurende uw opleiding bij meerdere bedrijven of organisaties gewerkt?

1 ja, meerdere bedrijven/organisaties

2 nee, slechts bij één bedrijf

Indien hier antwoord 1 wordt gegeven, dan gaan de vragen 10a tot en met 12 over het bedrijf waar men het grootste deel van de opleidingstijd heeft doorgebracht. 
Neem bij werkperiodes van gelijke lengte de meest recente werkperiode en het daarbijbehorende bedrijf.

10a Van wanneer tot wanneer had u dit werk?

van......................(maand/jaar) tot en met.... (maand/jaar)

10b Was dit een door de overheid gesubsidieerde arbeidsplaats, bijvoorbeeld via de Wet Inschakeling Werkzoekenden (WIW) of het Jeugdwerkgarantieplan (JWG)?

1 ja

2 nee

3 weet ik niet

10c Wat was de naam van uw functie? ENQ: Voorbeelden noemen als men moeite heeft met het beantwoorden: lasser, verkoper, automonteur, secretaresse, ziekenverzorgende. Spontaan laten antwoorden. Let op: Doorvragen of het dezelfde functie is, indien er meerdere BBL-opleidingen zijn gevolgd!

1 dezelfde functie als tijdens een eerdere BBL-opleiding

2 andere functie, namelijk

10d Wat waren uw voornaamste werkzaamheden? ENQ: Voorbeelden noemen als men moeite heeft met het beantwoorden: technisch tekenen, verkopen van kleding, schilderen, bloemen telen, boekhouden.

10e In wat voor organisatie of bedrijf werkte u? (bv. machinefabriek, garagewerkplaats, kledingwinkel, hotel, ziekenhuis) Spontaan laten antwoorden. Let op: Doorvragen of het hetzelfde bedrijf is, indien er meerdere BBL-opleidingen zijn gevolgd!

1 hetzelfde bedrijf als tijdens een eerdere BBL-opleiding $\rightarrow$ ga naar vraag 11d

2 andere bedrijf, namelijk.

$10 \mathrm{~W}$ Wat voor soort product of dienst leverde het bedrijf of de organisatie voornamelijk?

(bv landbouwmachines, bouwtechnisch advies, drukwerk, medische verzorging)

10g Hoeveel mensen werken er in totaal bij dit bedrijf? ENQ.: het gaat hier om alle werknemers van het totale concern (hoofd- en nevenvestigingen samen) in Nederland.

1 (aantal invullen)

$2 \quad$ weet ik niet

11a Welk opleidingsniveau werd door uw werkgever op het moment dat $u$ bij hem in dienst kwam minimaal voor deze functie vereist? ENQ: Spontaan 
laten antwoorden. Let op: het gaat om het niveau bij in dienst treden, niet om het niveau van de BBL-opleiding.

1 basisonderwijs voldoende

2 tenminste VBO $\rightarrow$ ga naar vraag $11 \mathrm{~b}$. Alle overige antwoorden naar vraag $11 \mathrm{c}$

3 tenminste MAVO

4 tenminste HAVO, VWO

5 tenminste kort $\mathrm{MBO},(\mathrm{KMBO})$

6 tenminste primair leerlingwezen

7 tenminste $\mathrm{MBO}$

8 tenminste secundair/voortgezet leerlingwezen

9 weet ik niet

11b Werden er door uw werkgever eisen gesteld aan het niveau waarop u examen heeft gedaan? ENQ: Voorbeeld geven: twee vakken op C-niveau.

1 ja, namelijk....

2 nee

3 weet ik niet

11c Welke opleidingsrichting werd door uw werkgever op het moment dat u bij hem in dienst kwam voor deze functie vereist? ENQ: Spontaan laten antwoorden.

$1 \quad$ uitsluitend mijn eigen opleidingsrichting

2 mijn eigen opleidingsrichting of een andere opleidingsrichting binnen mijn sector

3 een andere opleidingsrichting buiten mijn sector

$4 \quad$ geen specifieke opleidingsrichting

5 weet ik niet

11d Wat voor soort aanstelling was dit? (bij tijdelijke aanstelling ook het aantal maanden vragen) ENQ: Spontaan laten antwoorden.

1 tijdelijke aanstelling, voor........maanden zonder uitzicht op vaste baan

2 tijdelijke aanstelling, voor........maanden met uitzicht op vaste baan

3 vaste aanstelling of proeftijd voor vaste baan

12 Hoe vond $u$ de medewerking van het bedrijf bij het volgen van <OPLEIDING VRAAG 7A> ? ENQ: Antwoorden oplezen.

1 goed

2 voldoende

3 matig

4 slecht

13 Heeft $u$ de opleiding tussentijds onderbroken? Zo ja, voor hoeveel maanden?

1 ja, voor maanden

2 nee 
ENQ: Check of men de opleiding nog steeds volgt door middel van een controlerende vraag aan de respondent (“U volgt deze opleiding nog/niet meer. Klopt dat?")

Als men de opleiding nog volgt $\rightarrow$ ga naar vraag 19

Als men de opleiding niet meer volgt $\rightarrow$ ga naar vraag 14

14 Heeft $u$ van <OPLEIDING VRAAG 7A> een diploma behaald? ENQ: Doorvragen indien ja.

1 ja, zowel een praktijk- als theoriediploma $\rightarrow$ ga naar vraag 17

2 ja, alleen een praktijkdiploma $\rightarrow$ ga naar vraag 17

3 ja, alleen een theoriediploma $\rightarrow$ ga naar vraag 17

4 nee

15 Bent u binnen dezelfde opleiding nog naar een ander niveau overgestapt? ENQ: Spontaan laten antwoorden. Doorvragen indien "ja”.

1 ja, naar een hoger niveau

2 ja, naar een lager niveau

3 nee

16 Wat was de belangrijkste reden om <OPLEIDING VRAAG 7A> niet af te maken? ENQ: Maximaal twee antwoordcategorieën aankruisen. Spontaan laten antwoorden.

1 de opleiding viel inhoudelijk tegen/was niet zo interessant als ik dacht

$2 \quad i k$ vond de opleiding te moeilijk

$3 \quad$ ik wilde achteraf toch liever een andere opleiding gaan volgen

$4 \quad$ ik wilde liever voltijd gaan werken

$5 \quad$ ik had geen zin meer om te leren

$6 \quad$ ik had de opleiding niet nodig voor mijn werk

$7 \quad$ ik kreeg ander werk waarvoor ik de opleiding niet meer nodig had

$8 \quad$ ik kreeg ontslag

9 mijn werkgever wilde niet dat ik de opleiding volgde

10 de opleiding sloot niet aan bij <OPLEIDING1>

11 ik werd onvoldoende begeleid vanuit het (leer)bedrijf

12 anders, namelijk:

Vragen 17 en 18 niet stellen als vraag $8=4$

17 Bent u direct na uw opleiding bij hetzelfde bedrijf gebleven?

1 ja

2 nee $\rightarrow$ ga naar vraag 17

18 Bent u nog steeds werkzaam bij hetzelfde bedrijf?

1 ja

2 nee 
19 Zou u, achteraf bezien, opnieuw dezelfde keuze maken wat uw opleiding betreft? ENQ: Spontaan laten antwoorden.

1 ja, dezelfde BBL-opleiding

2 nee, andere BBL-opleiding, namelijk:

3 nee, BOL/AVO/VAVO-opleiding, namelijk:

4 nee, ik zou direct zijn gaan werken

5 nee, anders namelijk.

Indien men aan een andere BBL-opleiding is begonnen, doorloop blok 3 dan opnieuw, met uitzondering van de volgende vragen: $7 c, 7 d$, en $7 e$.

\section{Blok 4 Vragen betaald werk}

ENQ:

$U$ heeft aangegeven dat $u$ van $<$ MAAND $><$ JAAR $>$ tot $<$ MAAND $><$ JAAR $>$ betaald werk heeft verricht. We willen u een aantal vragen hierover stellen.

Vragen 20a, 20b, 20c en 20d alleen stellen aan diegenen die direct na $<$ OPLEIDING1> zijn gaan werken.

20a Heeft $u$ voordat $u$ begon met werken nog andere bezigheden overwogen, zoals een voltijd opleiding of een opleiding in het leerlingwezen?

$1 \quad$ ja, een voltijd opleiding

2 ja, een opleiding in het leerlingwezen

3 ja, anders namelijk....

4 nee

20b Wat was de belangrijkste reden om destijds direct na <OPLEIDING1> te gaan werken? ENQ: LET OP! Hier slechts de eerstgenoemde reden aankruisen. Overige antwoorden in vraag 20c aankruisen. Spontaan laten antwoorden.

$1 \quad$ ik kreeg interessant werk aangeboden

$2 \quad$ voor het beroep dat ik wilde had ik geen opleiding meer nodig

3 er was geen opleiding die me interesseerde

4 mijn ouders/verzorgers leek het beter dat ik ging werken

5 met werken kon ik gelijk gaan verdienen

$6 \quad i k$ wist niet zeker of ik een diploma van een opleiding zou kunnen halen

7 ik was niet meer leerplichtig en hoefde daarom geen opleiding meer te volgen

8 mijn werkgever wilde niet dat ik naast mijn werk nog een opleiding in het leerlingwezen zou volgen

$9 \quad$ ik wilde eigenlijk naar het leerlingwezen maar ik kon geen geschikte leerarbeidsplaats vinden

10 andere reden, namelijk: 
20c Waren er verder nog belangrijke redenen om destijds gelijk te gaan werken? ENQ: Overige antwoorden hier invullen. Maximaal twee antwoordcategorieën aankruisen. Spontaan laten antwoorden. Doorvragen bij twijfel over welke antwoordcategorie er aangekruist moet worden.

$1 \quad$ lk kreeg interessant werk aangeboden

$2 \quad$ voor het beroep dat ik wilde had ik geen opleiding meer nodig

3 er was geen opleiding die me interesseerde

4 mijn ouders/verzorgers leek het beter dat ik ging werken

5 met werken kon ik gelijk gaan verdienen

$6 \quad$ ik wist niet zeker of ik een diploma van een opleiding zou kunnen halen

7 ik was niet meer leerplichtig en hoefde daarom geen opleiding meer te volgen

8 mijn werkgever wilde niet dat ik naast mijn werk nog een opleiding in het leerlingwezen zou volgen

$9 \quad$ ik wilde eigenlijk naar het leerlingwezen maar ik kon geen geschikte leerarbeidsplaats vinden

10 andere reden, namelijk:

20d Wat vindt $\mathrm{u}$ van de studie- en beroepskeuzevoorlichting die u tijdens $<O P L E I D I N G 1>$ ontvangen heeft? ENQ: Antwoorden oplezen.

goed

voldoende

matig

slecht

ik heb geen voorlichting ontvangen

21a Wat is de naam van uw functie? ENQ: Voorbeelden noemen als men moeite heeft met het beantwoorden: lasser, verkoper, automonteur, secretaresse, ziekenverzorgende.

21b Wat zijn uw voornaamste werkzaamheden? ENQ: Voorbeelden noemen als men moeite heeft met het beantwoorden: technisch tekenen, verkopen van kleding, schilderen, bloemen telen, boekhouden.

21c In wat voor organisatie of bedrijf werkt $u$ ?

(bv. machinefabriek, garagewerkplaats, kledingwinkel, hotel, ziekenhuis)

21d Wat voor soort product of dienst levert het bedrijf of de organisatie voornamelijk?

(bv landbouwmachines, bouwtechnisch advies, drukwerk, medische verzorging) 
21e Hoeveel mensen werken er in totaal bij dit bedrijf? ENQ.: het gaat hier om alle werknemers van het totale concern (hoofd- en nevenvestigingen samen) in Nederland.

1 (aantal invullen)

2 weet ik niet

Hoe bent $u$ aan deze baan gekomen? ENQ: Let op maar één antwoord mogelijk. Spontaan laten antwoorden.

1 via het arbeidsbureau

2 via uitzendbureau, commercieel bemiddelingsbureau

3 gereageerd op advertentie

$4 \quad$ via open sollicitatie

5 via stage

$6 \quad$ via school

7 via bedrijveninformatiedagen, banenmarkt of open dag bedrijf

8 via eerder werk, interne vacature

9 via familie, vrienden of kennissen

10 bedrijf of praktijk zelf begonnen

11 bedrijf of praktijk overgenomen (bv. van ouders)

12 anders, namelijk

23a Welk opleidingsniveau werd door uw werkgever minimaal voor deze functie vereist toen $u$ in deze functie begon? ENQ: Spontaan laten antwoorden.

1 basisonderwijs voldoende

2 tenminste VBO $\rightarrow$ ga naar vraag 23b. Alle overige antwoorden naar vraag $23 c$

tenminste MAVO

tenminste HAVO, VWO

tenminste kort $\mathrm{MBO}$, (KMBO)

tenminste primair leerlingwezen

tenminste MBO

tenminste secundair leerlingwezen

weet ik niet

23b Werden er door uw werkgever eisen gesteld aan het niveau waarop $u$ examen heeft gedaan? ENQ: Voorbeeld geven: twee vakken op C-niveau.

1 ja, namelijk....

2 nee

3 weet ik niet

23c Welke opleidingsrichting werd door uw werkgever vereist voor deze functie toen $u$ in deze functie begon? ENQ: Spontaan laten antwoorden.

1 uitsluitend mijn eigen opleidingsrichting

2 mijn eigen opleidingsrichting of een andere opleidingsrichting binnen mijn sector

3 een andere opleidingsrichting buiten mijn sector 
geen specifieke opleidingsrichting

5 weet ik niet

24 In wat voor dienstverband werkt $u$ in deze baan? ENQ: Spontaan laten antwoorden.

1 werk via uitzendbureau

2 loondienst bij werkgever

3 oproepkracht, 0-uren - of min-/max contract

$4 \quad$ werkervaringsproject (bv. WIW of JWG)

5 werk in bedrijf ouders/partner

6 zelfstandige in eigen bedrijf (incl. maatschap) of free-lance

7 anders, namelijk

25 Wat voor soort aanstelling is dit? (bij tijdelijke aanstelling ook het aantal maanden vragen) ENQ: Spontaan laten antwoorden.

1 tijdelijke aanstelling, voor.......maanden zonder uitzicht op vaste baan

2 tijdelijke aanstelling, voor........maanden met uitzicht op vaste baan vaste aanstelling of proeftijd voor vaste baan

Hoeveel uren werkt u per week volgens uw contract? uren per week

27a Is het mogelijk om in het kader van uw werk een opleiding of cursus te volgen?

$1 \quad$ ja $\rightarrow$ ga naar vraag 28

2 nee

27b Heeft $u$ in het kader van uw werk een opleiding of cursus gevolgd? ENQ: Niet de opleiding zoals die in blok 2 of 3 reeds is aangegeven.

1 nee $\rightarrow$ ga naar vraag 28

2 ja

27c Op wiens initiatief heeft u deze opleiding(en) gevolgd? ENQ: Spontaan laten antwoorden.

$1 \quad$ op mijn initiatief

2 op initiatief van de werkgever

3 op zowel eigen initiatief als op initiatief van de werkgever

27d Wat was de belangrijkste reden om deze cursus/opleiding te gaan volgen? ENQ: Spontaan laten antwoorden.

bijscholing voor functie <VRAAG 21A>

omscholing voor andere functie

om een hogere functie te kunnen vervullen

om meer kansen te hebben op de arbeidsmarkt

om mezelf verder te ontplooien

anders, namelijk..... 
Volgende vraag hoeft alleen gesteld te worden voor zover het de huidige functie betreft.

28 Hoeveel verdient u bruto in deze functie? (toeslagen, onregelmatige dienst, fooi, provisie e.d. tellen wel mee / overwerk, vakantiegeld, 13e maand, uitkering, (studie)beurs e.d. en eventuele nevenfuncties tellen niet mee / ga bij wisselende verdiensten uit van het gemiddelde) bruto:. gulden per

1 maand

2 vier weken

3 week

Onderstaande vraag alleen stellen als men direct is gaan werken na <OPLEIDING $1>$.

29 Zou u, acheraf bezien, opnieuw dezelfde keuze maken om direct te gaan werken? ENQ: Spontaan laten antwoorden.

1 ja, ik zou weer hetzelfde werk kiezen

2 ja, maar ik zou ander werk kiezen

3 nee, zou een BOL/AVO/VAVO-opleiding volgen, namelijk

4 nee, zou een BBL-opleiding volgen, namelijk:

5 nee, anders namelijk

Ga naar de kalender en zie de volgende periode.

\section{Blok 5 Vragen over maatschappelijke positie werkloos}

ENQ:

$U$ heeft aangegeven dat $u$ van $<$ MAAND $><$ JAAR $>$ tot $<$ MAAND $><$ JAAR $>$ werkloos bent (geweest). We willen $u$ daar een aantal vragen over stellen.

30a Had/heeft u gedurende deze maanden recht op een uitkering?

1 ja

2 nee

30b Wat was dit voor een uitkering? ENQ: Spontaan laten antwoorden.

1 een WW-uitkering

2 een bijstandsuitkering

3 anders, namelijk:

Vragen $30 \mathrm{ct} / \mathrm{m}$ 30e alleen stellen indien de huidige status werkloos is.

30c Heeft $u$ in de afgelopen vier weken iets gedaan om aan betaald werk te komen? ENQ: Spontaan laten antwoorden.

1 ja

2 nee

3 nee, maar ik wacht op de uitkomst van lopende sollicitaties 
30d Als u nu een andere baan zou vinden, wanneer zou u dan daarmee kunnen beginnen? ENQ: Antwoorden oplezen.

binnen 2 weken $\rightarrow$ ga naar blok 6

2 tussen 2 weken en 3 maanden $\rightarrow$ ga naar blok 6

3 na 3 maanden

30e Waarom kunt u niet eerder beginnen? ENQ: Spontaan laten antwoorden.

1 afronden onbetaald werk/vrijwilligerswerk

2 regelen kinderopvang

3 vakantie

$4 \quad$ ziekte

5 anders, namelijk...........

\section{Blok 6 Competenties}

ENQ:

$\mathrm{Bij}$ de volgende vraag is het de bedoeling dat $\mathrm{u}$ uw kennis en vaardigheden op een aantal gebieden beoordeelt met een rapportcijfer van $1 \mathrm{t} / \mathrm{m} \mathrm{10}$. We zouden ook graag willen weten waar $u$ deze kennis en vaardigheden voornamelijk heeft opgedaan: in <OPLEIDING1>, <OPLEIDING2>, <OPLEIDING7A>, of in uw functie <VRAAG 21A> (NB. zie wat van toepassing is).

$\mathrm{Na}$ elk gegeven cijfer direct noteren waar men de kennis heeft opgedaan.

31 Hoe beoordeelt $u$ op dit moment uw (1 t/m 11) ?

Waar heeft $\mathrm{u}$ deze kennis voornamelijk opgedaan?

ENQ: Hier kunnen eventueel maximaal twee antwoordcategorieën worden aangekruist.

MAVO of VBO

BOL/AVO/VAVO-opleiding

BBL-opleiding

werk

Aspect

Cijfer

Waar opgedaan?

$1 \quad$ Kennis van uw eigen vakgebied

$2 \quad$ Praktische vaardigheden in uw eigen vakgebied

$3 \quad$ Kennis op het gebied van computers

$4 \quad$ Beheersing van buitenlandse talen

$5 \quad$ Vaardigheid in plannen/organiseren

$6 \quad$ Mondelinge presentatie

7 Schriftelijke presentatie

8 Vaardigheid in het oplossen van problemen

9 Vaardigheid in het werken in teamverband

10 Zelfstandigheid

11 Nauwkeurigheid 


\section{Blok 7 Afsluitende algemene vragen}

32 Hoe is uw huishouden samengesteld? ENQ: Spontaan laten antwoorden.

1 gehuwd/samenwonend met kind(eren) $\rightarrow$ beantwoord vraag 33, 34, 35, daarna: vraag 36

2 gehuwd/samenwonend zonder kinderen $\rightarrow$ beantwoord vraag 33, 34, daarna: vraag 36

3 alleenstaand met kind(eren) $\rightarrow$ beantwoord vraag 33, 35, daarna: vraag 36

$4 \quad$ alleenstaand zonder kinderen $\rightarrow$ beantwoord vraag 33, daarna: vraag 36

$5 \quad$ thuiswonend $\rightarrow$ ga naar vraag 36

33 Wanneer bent $u$ zelfstandig gaan wonen? ENQ: Tel het samenwonen met mensen anders dan de partner (huisgenoten e.d) ook als zelfstandig wonen.

1 maand........

2 jaar.....

$34 \quad$ Wanneer bent u gaan samenwonen?

1 maand........

2 jaar

$35 \quad$ Wanneer is/zijn uw kind(eren) geboren?

kind 1: maand jaar.

kind 2: maand. jaar.

kind 3: maand.

jaar.

36 Wat is het hoogst behaalde opleidingsniveau van uw ouders? Geef voor beide ouders de opleiding aan.

Vader Moeder

lagere school

lagere beroepsopleiding

MAVO of MULO

HAVO of MMS

VWO, HBS of Gymnasium

$\mathrm{MBO}$

$\mathrm{HBO}$

universiteit

37a In welk land bent u geboren?

$1 \quad$ Nederland

2 ander land, namelijk...............

37b In welk land zijn uw ouders geboren?

Vader Moeder

$1 \quad$ Nederland

2 ander land, namelijk 
38a Heeft u na het verlaten van <OPLEIDING VRAAG1> een cursus of opleiding buiten werkverband gevolgd? ENQ: Geen hobbycursussen of cursussen die al eerder aan de orde zijn gekomen.

1 ja

2 nee $\rightarrow$ ga naar vraag 39

38b Wat was de belangrijkste reden om deze cursus/opleiding te gaan volgen? ENQ: Spontaan laten antwoorden.

1 bijscholing voor de functie waar ik toen werkzaam was

2 omscholing voor andere functie

3 om een hogere functie te kunnen vervullen

4 om meer kansen te hebben op de arbeidsmarkt

5 om mezelf verder te ontplooien

6 anders, namelijk.....

39 Zou $\mathrm{u}$ in de komende vijf jaar nog aan een langdurige opleiding willen beginnen?

1 ja

2 nee

40 Wat denkt u dat over vijf jaar uw belangrijkste bezigheid is? ENQ: Spontaan laten antwoorden.

1 onbetaald werk

2 vervolgopleiding BOL/AVO/VAVO

3 vervolgopleiding in het leerlingwezen/BBL

4 betaald werk

5 werkloos/werkzoekend

6 zorgtaken/huishouden

7 vervolgopleiding $\mathrm{HBO}$

8 anders, namelijk

Dit is het einde van de vragenlijst. Hartelijk bedankt voor uw medewerking! 


\section{Bijlage 3: Aanvullende vragenlijst}

Uitleg beslisregel:

lemand zit in het leerlingwezen/ inservice als:

- $\quad$ hij zelf aangeeft een opleiding in het leerlingwezen te volgen

- $\quad$ hij een opleiding in het kader van het werk volgt die officieel 'minimaal een jaar duurt en waarbij men hetzij één of twee dagen per week naar school gaat (maar geen particulier instituut), hetzij aangeeft de opleiding aan de streekschool, centrum vakopleiding, MBO of ziekenhuis te volgen.

\section{Introductie}

Goedemiddag/avond, u spreekt met .... van Desan Marktonderzoek. Wij hebben vorig jaar telefonisch een interview met <naam respondent> gehouden over zijn/haar loopbaan in het kader van een landelijk schoolverlatersonderzoek. Zou ik hem/haar even mogen spreken?

1 respondent woont NIET meer op dit adres $\rightarrow$ telefoonnummer vragen

2 respondent woont op dit adres:

a nu geen tijd/niet aanwezig $\rightarrow$ afspraak maken

b $\quad$ nu tijd $\rightarrow$ vervolg introductie

<Indien juiste persoon aan de lijn>

(Indien respondent voor het eerst aan de lijn komt: Goedemiddag/avond, u spreekt met .... van Desan Marktonderzoek. Wij hebben vorig jaar telefonisch een interview met $\mathrm{u}$ gehouden over uw loopbaan in het kader van een landelijk schoolverlatersonderzoek.)

In 199.... heeft $u$ de/het <opleiding > aan de/het <naam school> afgerond? (check of het om de juiste respondent gaat aan de hand van RUBS '94/'95).

Wij zijn nu bezig met het analyseren van de gegevens. Helaas zijn er nog een paar onduidelijkheden waardoor we het onderzoek niet goed verder kunnen uitvoeren. Wij zouden $u$ daarom graag een paar aanvullende vragen willen stellen. Dit duurt maximaal tien minuten. Het zou erg behulpzaam zijn voor het onderzoek. Heeft $u$ daar nu misschien tijd voor? Zo ja, $\rightarrow$ start vragenlijst. Zo nee $\rightarrow$ afspraak maken.

\section{Groep 1}

In RUBS-meting wel BBL, in BVE-meting geen BBL

Een klein jaar na het verlaten van de/het <opleiding> heeft u een vragenlijst ingevuld.

$1 \quad$ Daarin hebben wij staan dat $u$ in <periode tijdstip invullen enquete RUBS '94/ '95> de volgende opleiding deed: <oplnaam> Klopt dat:

2 ja $\rightarrow$ ga naar vraag 3

3 nee, ik deed toen een andere opleiding $\rightarrow$ ga naar vraag 2 
4 nee, ik had toen werk $\rightarrow$ ga naar vraag 7

5 nee, anders, namelijk $\rightarrow$ ga naar vraag 17

\section{Opleiding}

$1 \quad$ Wat is de naam van deze opleiding?

naam opleiding

$2 \quad$ Was dit een opleiding in het leerlingwezen of een in-service opleiding? Daarmee wordt een opleiding bedoeld die gecombineerd wordt met werk. Je gaat dan meestal 1 of 2 dagen per week naar school en de rest van de week heb je werk.

$3 \quad$ ja $\rightarrow$ statussen in kalenderoverzicht aanpassen en blok BBL (oude lijst) vraag $7 \mathrm{a} \mathrm{t} / \mathrm{m} 19$ doorlopen + vraag $27 \mathrm{a} \mathrm{t} / \mathrm{m} \mathrm{27d}$

\section{Aanpassing statussen in kalenderoverzicht}

Vragen:

$1 \quad$ In welke periode heeft $u$ deze opleiding in het leerlingwezen gevolgd? $\rightarrow$ in de kalender deze nieuwe periode invoeren

2 Ik wil graag nogmaals met $u$ doorlopen wat $u$ direct na de/het <opleiding> (=mavo/vbo) bent gaan doen. Ik lees op welke gegevens $u$ de vorige keer heeft doorgegeven. Zou $u$ het kunnen zeggen als er iets niet klopt? $\rightarrow$ alle statussen zoals die zijn ingevuld oplezen en checken of dit klopt. Indien nodig aanpassen.

\section{Doorlopen BBL-blok en vraag 27a t/m 27d over bedrijfsopleidingen}

Vraag 7a eventueel aanpassen als de naamvan de opleiding al bekend is (dit geldt alleen voor groep 1) dus verander de vraag in: Weet $u$ ook tot welk landelijk orgaan de opleiding ... behoort? (zie instructie vraag 7a)

Vraag $7 \mathrm{c} \mathrm{t/m}$ 7e alleen stellen als de start van de BBL opleiding binnen één jaar na het verlaten van de VBO of Mavo opleiding uit 93 of 94 plaats vindt

Vragen 27a t/m 27d gaan over het werk dat men na afloop van de BBLopleiding (vr. 7a t/m 19 had)

We willen nu nog een paar vragen stellen over het werk dat u direct na afloop van de leerlingwezen of in-service opleiding bent gaan volgen

Vraag 27a: Was het mogelijk om in het kader van het dit werk een opleiding of cursus te volgen?

Vraag 27a: $\quad$ Indien nee: einde vragenlijst met als eindvraag geb.datum.

Vraag 27b: $\quad$ Heeft $u$ in het kader van dit werk een opleiding of cursus gevolgd?

Vraag 27c: $\quad$ Op wiens initiatief heeft $u$ deze opleiding gevolgd?

Vraag 27d: zie oorspronkelijke lijst

2 nee $\rightarrow 4 a$ 
4a Hoeveel dagen per week moest u officieel voor uw opleiding naar school?

15 dagen

23 à 4 dagen

31 à 2 dagen

4 anders, $\mathrm{nl}$.

4b Hoe lang duurde de opleiding officieel?

1 Minder dan één jaar $\rightarrow 12$

2 Één jaar of meer $\rightarrow 5$

$5 \quad$ Moest $u$ voor uw opleiding een leerarbeidsplaats of werk hebben?

1 ja

2 ja, maar volgde op school het praktijkgedeelte

3 nee

$6 \quad$ Waar volgde u deze opleiding?

1 Streekschool

2 Ziekenhuis

$3 \quad \mathrm{MBO} / \mathrm{grafisch}$ lyceum

$4 \quad$ Centrum voor Vakopleiding

5 School voor voortgezet onderwijs

6 Particuliere instelling (PBNA, LOI, Schoevers, NTI, e.d.)

$7 \quad$ Kort verbands vrijwilliger

8 Anders, namelijk

$9 \quad$ Weet niet

Beslisregel

- $\quad$ indien $(4 a .=c$ of $5 .=a / b$ of $6=a / b / c / d)$ én $(4 b=$ niet $a)$ én $(6=$ niet $f) \rightarrow B B L$

- $\quad$ Indien BBL $\rightarrow$ statussen in kalender aanpassen en blok BBL (oude lijst) vraag $7 \mathrm{a} \mathrm{t} / \mathrm{m} 19$ doorlopen + vraag 27a t/m 27d (Let op opmerkingen; 3a) Indien geen $\mathrm{BBL} \rightarrow$ naar vraag 12

\section{Betaald werk}

$7 \quad$ Heeft $\mathrm{u}$ toen in het kader van uw werk een opleiding gedaan?

1 ja, één opleiding

2 ja, meerdere opleidingen

$3 \quad$ nee $\rightarrow$ naar vraag 12

Indien meerdere opleidingen doorloop de vragen 8-11 voor elk van deze opleidingen

$8 \quad$ Wat is de naam van deze opleiding?

naam opleiding

$9 \quad$ Was dit een opleiding in het leerlingwezen of een in-service opleiding? Daarmee wordt een opleiding bedoeld die gecombineerd wordt met werk. Je 
gaat dan meestal 1 of 2 dagen per week naar school en de rest van de week heb je werk.

$1 \quad$ ja $\rightarrow$ statussen in kalenderoverzicht aanpassen en blok BBL (oude lijst) vraag $7 \mathrm{a} \mathrm{t/m} 19$ doorlopen + vraag 27a t/m 27d (let op opmerkingen ; 3a)

10a Hoeveel dagen per week moest u officieel voor uw opleiding naar school?

15 dagen

23 à 4 dagen

31 à 2 dagen

4 anders, $\mathrm{nl}$.

10b Hoe lang duurde de opleiding officieel?

$1 \quad$ Minder dan één jaar $\rightarrow 12$

2 Één jaar of meer $\rightarrow 11$

$11 \quad$ Waar volgde u deze opleiding?

1 Streekschool

2 Ziekenhuis

$3 \mathrm{MBO} / \mathrm{grafisch}$ lyceum

$4 \quad$ Centrum voor Vakopleiding

$5 \quad$ School voor voortgezet onderwijs

6 Particuliere instelling (PBNA, LOI, Schoevers, NTI, e.d.)

$7 \quad$ Kort verbands vrijwilliger

8 Anders, namelijk

$9 \quad$ Weet niet

Beslisregel

- $\quad$ indien $(10 a=c$ of $11=a / b / c / d)$ én $(10 b=$ niet $a)$ én $(11=$ niet $f) \rightarrow B B L$

- $\quad$ Indien BBL $\rightarrow$ statussen in kalender aanpassen en blok BBL (oude lijst) vraag $7 \mathrm{a} \mathrm{t/m} 19$ doorlopen + vraag $27 \mathrm{a} \mathrm{t/m} \mathrm{27d} \mathrm{(let} \mathrm{op} \mathrm{opmerkingen:} 3 a$ ) Indien geen $\mathrm{BBL} \rightarrow$ naar vraag 12

\section{Eventueel later BBL?}

12 Heeft u later in het kader van uw werk nog een opleiding gedaan?

1 ja, één opleiding

2 ja, meerdere opleidingen

3 nee $\rightarrow$ naar einde vragenlijst (geboortedatum)

Indien meerdere opleidingen: doorloop de vragen 13-16 voor elk van deze opleidingen

13 Wat is de naam van deze opleiding? naam opleiding 
14 Was dit een opleiding in het leerlingwezen of een in-service opleiding? Daarmee wordt een opleiding bedoeld die gecombineerd wordt met werk. Je gaat dan meestal 1 of 2 dagen per week naar school en de rest van de week heb je werk.

$1 \quad$ ja $\rightarrow$ statussen in kalenderoverzicht aanpassen en blok BBL (oude lijst) vraag $7 a$ t/m 19 doorlopen + vraag $27 a$ t/m 27d

2 nee $\rightarrow 15$

15a Hoeveel dagen per week moest u officieel voor uw opleiding naar school?

15 dagen

23 à 4 dagen

31 à 2 dagen

4 anders, nl.

15b Hoe lang duurde de opleiding officieel?

$1 \quad$ Minder dan één jaar $\rightarrow$ einde vragenlijst (geboortedatum)

2 Één jaar of meer $\rightarrow 16$

$16 \quad$ Waar volgde $u$ deze opleiding?

1 Streekschool

2 Ziekenhuis

$3 \mathrm{MBO} /$ grafisch lyceum

$4 \quad$ Centrum voor Vakopleiding

5 School voor voortgezet onderwijs

6 Particuliere instelling (PBNA, LOI, Schoevers, NTI, e.d.)

$7 \quad$ Kort verbands vrijwilliger

8 Anders, namelijk

$9 \quad$ Weet niet

Beslisregel:

- $\quad$ indien $(15 a .=c$ of $16=a / b / c / d)$ én $(15 b=$ niet $a)$ én $(16=$ niet $f) \rightarrow B B L$

- $\quad$ ndien $B B L \rightarrow$ statussen in kalender aanpassen en blok BBL (oude lijst) vraag 7 a t/m 19 doorlopen + vraag 27a t/m 27d

Indien geen BBL $\rightarrow$ naar einde vragenlijst (geboortedatum)

\section{lets anders gedaan}

17 Als $u$ niet de <oplnaam > hebt gedaan, wat bent $u$ dan in <periode $>$ gaan doen?

onbetaald werk

werkloos/werkzoekend

vakantie langer dan 1 maand

zorgtaken/huishouden

anders, namelijk 


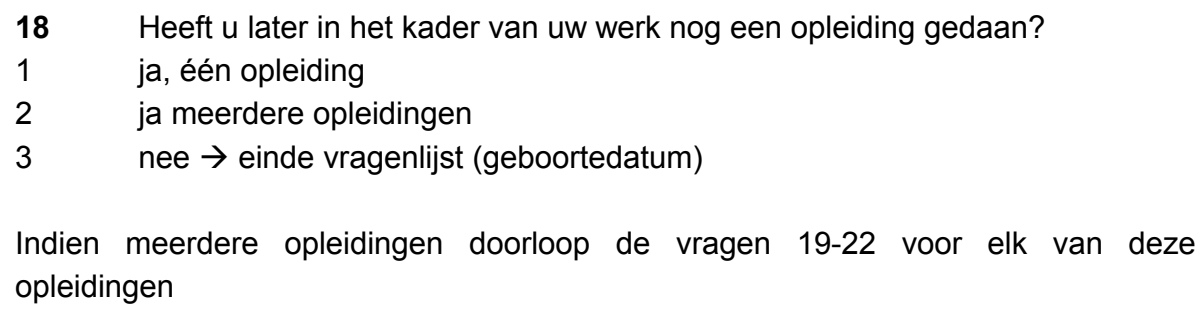

19 Wat is de naam van deze opleiding? naam opleiding

20 Was dit een opleiding in het leerlingwezen of een in-service opleiding? Daarmee wordt een opleiding bedoeld die gecombineerd wordt met werk. Je gaat dan meestal 1 of 2 dagen per week naar school en de rest van de week heb je werk.

$1 \quad$ ja $\rightarrow$ statussen in kalenderoverzicht aanpassen en blok BBL (oude lijst) vraag 7a t/m 19 doorlopen + vraag 27a t/m 27d (Let op opmerking: 3a)

2 nee $\rightarrow$ 21a

21a Hoeveel dagen per week moest u officieel voor uw opleiding naar school?

15 dagen

23 à 4 dagen

31 à 2 dagen

4 anders, $\mathrm{nl}$.

21b Hoe lang duurde de opleiding officieel?

$1 \quad$ Minder dan één jaar $\rightarrow$ einde vragenlijst (geboortedatum)

2 Één jaar of meer $\rightarrow 22$

$22 \quad$ Waar volgde u deze opleiding?

1 Streekschool

2 Ziekenhuis

$3 \mathrm{MBO} /$ grafisch lyceum

$4 \quad$ Centrum voor Vakopleiding

5 School voor voortgezet onderwijs

$6 \quad$ Particuliere instelling (PBNA, LOI, Schoevers, NTI, e.d.)

7 Kort verbands vrijwilliger

8 Anders, namelijk

9 Weet niet

Beslisregel

- $\quad$ indien $(21 a=c$ of $22=a / b / c / d)$ én $(21 b=$ niet $a)$ én $(22=$ niet $f) \rightarrow B B L$

- Indien BBL $\rightarrow$ statussen in kalender aanpassen en blok BBL (oude lijst) vraag $7 \mathrm{a} \mathrm{t/m} 19$ doorlopen + vraag 27a t/m 27d (let op opmerkingen: $3 a$ )

- $\quad$ Indien geen BBL $\rightarrow$ naar einde vragenlijst (geboortedatum) 


\section{Groep 2}

In RUBS-meting geen BBL, in BVE-meting minimaal 1x en maximaal $3 x$ aangegeven een opleiding te volgen in het kader van werk

$U$ heeft aangegeven dat $u$ in de periode van <start betaald werk: maand/jaar> tot en met <einde betaald werk: maand/jaar > bij <naam bedrijf> heeft gewerkt. Daarbij heeft $u$ een opleiding in het kader van uw werk gevolgd (indien dit niet het geval is $\rightarrow$ ga naar vraag 5). <NB gaat over het eerste blok waarbij is aangegeven dat men een opleiding in het kader van het werk gevolgd heeft> De volgende vragen gaan hierover.

$1 \quad$ Wat is de naam van deze opleiding?

naam opleiding

$2 \quad$ Was dit een opleiding in het leerlingwezen of een in-service opleiding? Daarmee wordt een opleiding bedoeld die gecombineerd wordt met werk. Je gaat dan meestal 1 of 2 dagen per week naar school en de rest van de week heb je werk.

$1 \quad$ ja $\rightarrow$ statussen in kalenderoverzicht aanpassen en blok BBL (oude lijst) vraag 7a t/m 19 doorlopen + vraag 27a t/m 27d (zie opmerkingen Groep1: 3a)

nee $\rightarrow 3 a$

3a Hoeveel dagen per week moest u officieel voor uw opleiding naar school?

15 dagen

23 à 4 dagen

31 à 2 dagen

4 anders, $\mathrm{nl}$.

3b Hoe lang duurde de opleiding officieel?

$1 \quad$ Minder dan één jaar $\rightarrow 5$

2 Één jaar of meer $\rightarrow 4$

$4 \quad$ Waar volgde u deze opleiding?

1 Streekschool

2 Ziekenhuis

$3 \quad \mathrm{MBO} /$ grafisch lyceum

$4 \quad$ Centrum voor Vakopleiding

5 School voor voortgezet onderwijs

6 Particuliere instelling (PBNA, LOI, Schoevers, NTI, e.d.)

7 Kort verbands vrijwilliger

8 Anders, namelijk

$9 \quad$ Weet niet 
Beslisregel

- $\quad$ indien $(3 a=c$ of $4=a / b / c / d)$ én $(3 b=n i e t a)$ én $(4=$ niet $f) \rightarrow B B L$

- Indien BBL $\rightarrow$ statussen in kalender aanpassen en blok BBL (oude lijst) $v$ raag $7 \mathrm{a} \mathrm{t} / \mathrm{m} 19$ doorlopen + vraag 27a t/m 27d ( zie opmerkingen groep 1) Indien geen $\mathrm{BBL} \rightarrow$ naar vraag 5

$5 \quad$ Heeft u later in het kader van uw werk nog een opleiding gedaan?

1 ja, één opleiding

2 ja meerdere opleidingen

3 nee $\rightarrow$ naar einde vragenlijst (geboortedatum)

Indien meerdere opleidingen doorloop de vragen 6-8 voor elk van deze opleidingen

$6 \quad$ Wat is de naam van deze opleiding?

naam opleiding

$7 \quad$ Was dit een opleiding in het leerlingwezen of een in-service opleiding? Daarmee wordt een opleiding bedoeld die gecombineerd wordt met werk. Je gaat dan meestal 1 of 2 dagen per week naar school en de rest van de week heb je werk.

$1 \quad$ ja $\rightarrow$ statussen in kalenderoverzicht aanpassen en blok BBL (oude lijst) vraag 7 a t/m 19 doorlopen + vraag 27 a t/m 27d (zie opmerkingen groep 1)

2 nee $\rightarrow 8 a$

8a Hoeveel dagen per week moest u officieel voor uw opleiding naar school?

15 dagen

23 à 4 dagen

31 à 2 dagen

$4 \quad$ anders, nl.

8b Hoe lang duurde de opleiding officieel?

$1 \quad$ Minder dan één jaar $\rightarrow$ einde vragenlijst (geboortedatum)

2 Één jaar of meer $\rightarrow 9$

$9 \quad$ Waar volgde u deze opleiding?

1 Streekschool

2 Ziekenhuis

$3 \quad \mathrm{MBO} /$ grafisch lyceum

$4 \quad$ Centrum voor Vakopleiding

5 School voor voortgezet onderwijs

6 Particuliere instelling (PBNA, LOI, Schoevers, NTI, e.d.)

7 Kort verbands vrijwilliger

8 Anders, namelijk

9 Weet niet 
Beslisregel

- $\quad$ indien $(8 a=c$ of $9=a / b / c / d)$ én $(8 b=$ niet $a)$ én $(9=$ niet $f) \rightarrow$ BBL

- $\quad$ Indien BBL $\rightarrow$ statussen in kalender aanpassen en blok BBL (oude lijst)

vraag $7 \mathrm{a} \mathrm{t} / \mathrm{m} 19$ doorlopen + vraag $27 \mathrm{a} \mathrm{t/m} \mathrm{27d} \mathrm{(zie} \mathrm{opmerkingen} \mathrm{groep} \mathrm{1)}$

Indien geen BBL $\rightarrow$ naar einde vragenlijst (geboortedatum)

10 Tot slot, mag ik weten wat uw geboortedatum is?

\section{Groep 3}

Overig: zowel in RUBS-meting als BVE-meting geen BBL en ook geen opleiding in het kader van werk en ook geen diploma behaald in voltijd vervolgonderwijs

$1 \quad$ Heeft u ooit in het kader van uw werk een opleiding gedaan?

1 ja, één opleiding

2 ja, meerdere opleidingen

3 nee $\rightarrow$ naar einde vragenlijst (geboortedatum)

Indien meerdere opleidingen doorloop de vragen 2-4 voor elk van deze opleidingen

$2 \quad$ Wat is de naam van deze opleiding?

naam opleiding

$3 \quad$ Was dit een opleiding in het leerlingwezen of een in-service opleiding? Daarmee wordt een opleiding bedoeld die gecombineerd wordt met werk. Je gaat dan meestal 1 of 2 dagen per week naar school en de rest van de week heb je werk.

1 ja $\rightarrow$ statussen in kalenderoverzicht aanpassen en blok BBL (oude lijst) vraag 7a t/m 19 doorlopen + vraag 27a t/m 27d (zie opmerkingen groep1)

2 nee $\rightarrow 4 a$

4a Hoeveel dagen per week moest u officieel voor uw opleiding naar school?

15 dagen

23 à 4 dagen

31 à 2 dagen

4 anders, $\mathrm{nl}$

4b Hoe lang duurde de opleiding officieel?

$1 \quad$ Minder dan één jaar $\rightarrow$ einde vragenlijst (geboortedatum)

2 Één jaar of meer $\rightarrow 5$

$5 \quad$ Waar volgde $u$ deze opleiding?

1 Streekschool

2 Ziekenhuis

$3 \quad \mathrm{MBO} / \mathrm{grafisch}$ lyceum

$4 \quad$ Centrum voor Vakopleiding

$5 \quad$ School voor voortgezet onderwijs

6 Particuliere instelling (PBNA, LOI, Schoevers, NTI, e.d.) 
$7 \quad$ Kort verbands vrijwilliger

8 Anders, namelijk.

9 Weet niet

Beslisregel

- $\quad$ indien $(4 a=c$ of $5=a / b / c / d)$ én $(4 b=$ niet $a)$ én $(5=$ niet $f) \rightarrow B B L$

Indien $\mathrm{BBL} \rightarrow$ statussen in kalender aanpassen en blok BBL (oude lijst)

vraag $7 \mathrm{a} \mathrm{t/m} 19$ doorlopen + vraag 27a t/m 27d (zie opmerkingen groep 1)

- $\quad$ Indien geen BBL $\rightarrow$ naar einde vragenlijst (geboortedatum)

$6 \quad$ Tot slot, mag ik weten wat uw geboortedatum is?

\section{Groep 4}

Overig: zowel in RUBS-meting als BVE-meting geen BBL en ook geen opleiding in het kader van werk en wel een diploma in voltijd vervolgonderwijs

$1 \quad$ Heeft u ooit in het kader van uw werk een opleiding gedaan?

1 ja, één opleiding

2 ja, meerdere opleidingen

3 nee $\rightarrow$ naar einde vragenlijst (geboortedatum)

Indien meerdere opleidingen doorloop de vragen 2-4 voor elk van deze opleidingen

$2 \quad$ Wat is de naam van deze opleiding?

naam opleiding

$3 \quad$ Was dit een opleiding in het leerlingwezen of een in-service opleiding? Daarmee wordt een opleiding bedoeld die gecombineerd wordt met werk. Je gaat dan meestal 1 of 2 dagen per week naar school en de rest van de week heb je werk.

$1 \quad a \rightarrow$ statussen in kalenderoverzicht aanpassen en blok BBL (oude lijst) vraag 7a t/m 19 doorlopen + vraag 27a t/m 27d (zie opmerkingen groep1)

2 nee $\rightarrow 4 a$

4a Hoeveel dagen per week moest u officieel voor uw opleiding naar school?

15 dagen

23 à 4 dagen

31 à 2 dagen

4 anders, $\mathrm{nl}$.

4b Hoe lang duurde de opleiding officieel?

1 Minder dan één jaar $\rightarrow$ einde vragenlijst (geboortedatum)

2 Één jaar of meer $\rightarrow 5$

$5 \quad$ Waar volgde u deze opleiding?

1 Streekschool

$2 \quad$ Ziekenhuis 
$3 \mathrm{MBO} /$ grafisch lyceum

$4 \quad$ Centrum voor Vakopleiding

5 School voor voortgezet onderwijs

6 Particuliere instelling (PBNA, LOI, Schoevers, NTI, e.d.)

$7 \quad$ Kort verbands vrijwilliger

8 Anders, namelijk.

9 Weet niet

Beslisregel

- $\quad$ indien $(4 a=c$ of $5=a / b / c / d)$ én $(4 b=$ niet $a)$ én $(5=$ niet $f) \rightarrow B B L$

- Indien BBL $\rightarrow$ statussen in kalender aanpassen en blok BBL (oude lijst) vraag $7 \mathrm{a}$ t/m 19 doorlopen + vraag $27 \mathrm{a} \mathrm{t/m} \mathrm{27d} \mathrm{(zie} \mathrm{opmerkingen} \mathrm{groep} \mathrm{1)}$ Indien geen $\mathrm{BBL} \rightarrow$ naar einde vragenlijst (geboortedatum)

6 Tot slot, mag ik weten wat uw geboortedatum is? 
